SJ Quinney College of Law, University of Utah

Utah Law Digital Commons

1989

Taking Account of the Ecosystem on the Public Domain: Law and Ecology in the Greater Yellowstone Region

Robert B. Keiter

Follow this and additional works at: https://dc.law.utah.edu/scholarship

Part of the Environmental Law Commons, and the Natural Resources Law Commons 


\title{
TAKING ACCOUNT OF THE ECOSYSTEM ON THE PUBLIC DOMAIN: LAW AND ECOLOGY IN THE GREATER YELLOWSTONE REGION
}

\author{
ROBERT B. KEITER* \\ TABLE OF CONTENTS
}

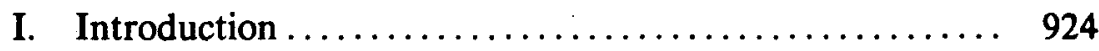

II. Ecology and the Public Lands................. 929

III. Yellowstone as an Ecosystem .................... 933

A. The Natural Environment ................ 933

B. Interjurisdictional Conflict: Economics and the Environment .......................... 937

C. The Cumulative Impact Problem............. 942

IV. Law and Ecology: Management Under Conflicting

Philosophies ............................. 943

A. The Preserved Lands: Restraint Beyond the Border?.................................. 944

1. The National Parks ....................... 944

2. Wilderness $\ldots \ldots \ldots \ldots \ldots \ldots \ldots \ldots \ldots \ldots \ldots .651$

B. Wildlife: The Irrelevance of Conventional

Boundaries ............................. 956

1. Endangered Species ..................... 956

2. Biological Diversity ................... 963

C. The Multiple Use Lands: A Struggle for

1. An Overview ....................... 968

2. Timber: Slipping from Dominance?......... 972

3. Oil and Gas: Moving Up on the Agenda?...... 975

4. Wilderness Designation: A Lingering Conundrum ........................ 982

D. Interagency Coordination: The Quest for Common

Ground $\ldots \ldots \ldots \ldots \ldots \ldots \ldots \ldots \ldots \ldots, \quad 984$

* Professor of Law, University of Wyoming, Laramie, Wyoming. I am grateful to Joe Sax, Joel Selig, Richard Schneebeck, and Kate Fox for their helpful comments on earlier drafts of this article. I also am indebted to Sam Benham and Mary Beth Siemon, University of Wyoming law students, for their tireless research assistance. The George Hopper Faculty Research Fund at the University of Wyoming College of Law provided me with generous financial support while working on this project. 
1. Keeping Discretion Intact ............... 984

2. A Substantive Coordination Requirement? ..... 988

V. Ecosystem Management: Perspectives From the Law .... 991

A. De Facto Regionalism: Surmounting the Tradition of Discretion .............................. 992

B. An Emerging "Common Law" of Ecosystem

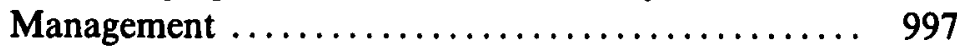

C. In Search of Guiding Principles............. 1001

VI. Conclusion $\ldots \ldots \ldots \ldots \ldots \ldots \ldots \ldots \ldots \ldots \ldots \ldots \ldots \ldots$

\section{INTRODUCTION}

An intense debate over federal public land management policy is currently underway throughout the western United States. As might be expected, the heart of this debate focuses on the question of preservation versus development-the central issue dominating public land policy controversies during much of this century. ${ }^{1}$ National parks, wilderness areas, and wildlife refuges are managed under a preservationist philosophy as enclaves where natural processes prevail and man's presence is minimized. ${ }^{2}$ Other public lands, however, are managed under a quite different multiple-use philosophy, which means they are open to such consumptive activities as timber harvesting, grazing, and mineral exploration. ${ }^{3}$ In fact, public land management policy in the West, until recently, has been dominated by a commit-

1. S. Udall, The Quiet Crisis 109-25 (1963); S. Dana \& S. Fairfax, Forest and Range Policy 108-11, 207-09 (2d ed. 1980). See also R. NASh, Wilderness AND the AMERICAN Mind 13340 (3d ed. 1982) (comparing the philosophies of Gifford Pinchot, chief architect of the Forest Service, who advocated the "conservative" use and development of the nation's public natural resources, and John Muir, founder of the Sierra Club and an early national parks advocate, who argued that natural areas should be preserved from development for their aesthetic and wilderness values). See generally G. Pinchot, Breaking New Ground (1947); J. Muir, Our National Parks (1901).

2. These "preserved" lands are managed by different federal agencies-principally the National Park Service, the Forest Service, and the U.S. Fish and Wildlife Service--under separate mandates, but the statutes generally reflect a common theme of retaining the lands in their original pristine state. See 16 U.S.C. $\$ 1$ (1982) (National Park Service Organic Act); 16 U.S.C. $\$ 1131$ (c) (1982) (Wilderness Act); 16 U.S.C. $\$ 668 d d$ (1982) (National Wildlife Refuge System Administration Act). See also infra section IV.A.

3. 16 U.S.C. $\$ \S 528-531$ (1982) (providing that the Secretary of Agriculture shall administer the national forests for multiple use-sustained yield purposes to provide for outdoor recreation, range, timber, watershed, wildlife, and fish); 43 U.S.C. $\$ 1712$ (c)(1) (1982) (providing that the Bureau of Land Management shall manage its public lands under a multiple-use principle that includes recreation, range, timber, minerals, watershed, wildlife, and fish purposes); 30 U.S.C. $\S 22$ (1982) (providing that the public lands are open for mineral exploration and development). See infra section IV.C. Private lands, often intermingled with the public lands, are generally not subject to federal regulation, and they too are usually open to development. The often thorny question of private land use and regulation adjacent to national parks and other "preserved" lands is a subject beyond the scope of this article. See generally Sax, Helpless Giants: National Parks and the Regulation of Private Lands, 75 MicH. L. REV. 239 (1976). 
ment to the exploitation and extraction of natural resources. But that tradition is now being eroded. ${ }^{4}$ Amenity values such as aesthetics, recreation, and wildlife preservation have become solidly entrenched as important dimensions of public land policy.5 Moreover, new environmental protection laws have imposed significant constraints on historic multiple-use activities. ${ }^{6}$

It has become increasingly evident that national park and wilderness lands, once buffered by undisturbed landscapes, do not exist in isolation. Sharing common watersheds, mountain ranges, and wildlife species, these lands are interconnected with the surrounding public and private lands; what occurs on adjacent lands can and often does dramatically impact them. The boundary lines defining political jurisdictional authority on the public domain simply do not reflect ecological realities. ${ }^{7}$ This problem has received prominent attention under the rubric of the national parks' external threats dilemma. ${ }^{8}$ Yet the same problem confronts many wilderness complexes and wildlife sanctuaries, which also are threatened by or experiencing environmental harm from adjacent activities. ${ }^{9}$

4. G. Robinson, The Forest Service 257.59 (1975); P. Culhane, Public Lands Politics:

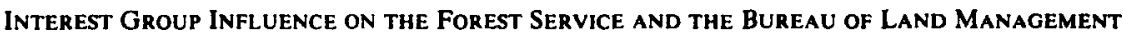
81-97 (1981). See also S. DANA \& S. FAIRFAX, supra note 1, at 179-206; Wilkinson \& Anderson, Land and Resource Planning in the National Forests, 64 OR. L. REV. 1, 69-70 (1985).

5. See, e.g., 42 U.S.C. § 4331(b)(2) (1982); 43 U.S.C. § 1702(c) (1982). See generally S. DANA \& S. FairfaX, supro note 1, at 179-265; S. Hays, Beauty, Health and Permanence: Environmen. tal Politics in the United States, 1955-1985, at 1-39 (1987).

6. See, e.g., Endangered Species Act of 1973, 16 U.S.C. $\$ \S 1531-1543$ (1982); National Environmental Policy Act of 1969, 42 U.S.C. $\$ \S 4321-4347$ (1982); Surface Mining Control and Reclamation Act of 1977, 30 U.S.C. $\$ \$ 1201-1328$ (1982).

7. When Congress has created national parks or wilderness areas, the boundaries of these enclaves invariably have reflected multiple political compromises; therefore, these areas rarely represent complete ecological units. A. Runte, National Parks: The American Experience 138-54 (2d ed. 1987); R. NASH, supra note 1, at 321. See generally Newmark, Legal and Biotic Boundaries of Western North American National Parks: A Problem of Congruence, 33 Biological Conservation 197-208 (1985); L. Harris, The Fragmented Forest: Ist.and Biogeography Theory and the PreserVATION OF BIOTIC DIVERSITY (1984).

8. See Office of Science \& Technology \& Nat'l Park Service, U.S. Dep't of the INTerior, State of the Parks 1980: A Report to the Congress (1980); U.S. General Accounting Office, Publ. No. GAO/RCED-87-36, Parks and Recreation: Limited Progress Made in Documenting and Mitigating Threats to the Parks (1987) (report to the Chairman, Subcomm. on National Parks and Recreation, House Comm. on Interior and Insular Affairs). See generally The Conservation found., National Parks for a New Generation: Visions, Realities, Prospects 126-29, 141-55 (1985); Our Common lands: Defending the National. PARKs (D. Simon ed. 1988) [hereinafter OUR COMMON LANDS]

9. For example, the Bob Marshall wilderness complex in Montana faces extensive oil and gas exploration on its perimeter, which will bring roads and heavy equipment up to the wilderness boundaries, potentially impacting water and air quality, as well as wildlife habitat. See Conner v. Burford, 848 F.2d 1441 (9th Cir.), cert. denied sub nom. Sun Exploration \& Prod. Co. v. Lujan, 109 S. Ct. 1121 (1989); Bob Marshall Alliance v. Hodel, 852 F.2d 1223 (9th Cir. 1988), cert. denied sub nom. Kohlman v. Alliance, 109 S. Ct. 1340 (1989). Park and wilderness lands in the North Cascades region are 
In an oft-cited 1943 essay accurately foreseeing just this problem, the eminent conservationist Aldo Leopold sets forth a powerful argument for a land management policy based upon a "land ethic" grounded in fundamental ecological principles. ${ }^{10}$ Echoing Leopold's concerns, the recent President's Commission on Americans Outdoors concluded that regional ecosystem planning was necessary to protect the integrity of the natural resource base on the public lands. ${ }^{11}$ Moreover, Congress has regularly-but thus far unsuccessfully-taken up national park protection legislation, ${ }^{12}$ while also undertaking piecemeal revision of outdated natural resource development laws, now hopelessly in conflict with contemporary environmental imperatives. ${ }^{13}$

The region surrounding Yellowstone National Park is in the forefront of the public land policy debate-a debate that is now being framed in terms of ecology and ecosystem dynamics. Yellowstone $\mathrm{Na}$ tional Park lies at the heart of a complex network of public, state, and private lands located in three states (Wyoming, Montana, and Idaho),

threatened by multiple impacts to water quality and wildlife habitat from clearcutting in the adjacent national forests. Friedman, Ecosystem on the Edge: Present Management of the GNCE, in FOREVER Wild: Conserving the Greater North Cascades Ecosystem 27-31 (M. Friedman ed. 1988). The plight of the Kesterson National Wildlife Refuge in California, which suffers from water pollution traced to nearby agricultural activities, has received broad national attention. Comment, Crisis at Kesterson: A Review of San Joaquin Valley Agricultural Drainage Problems and Possible Solutions, 5 UCLA J. Envtl. Law \& Pol'y 187 (1986). See also U.S. General Accounting Office, Wildlife Management: National Refuge Contamination Is Difficult to ConfiRm and Clean Up, GaO/ RCED-87-128 (1987) (report to the Chairman, Subcomm. on Oversight and Investigations of the House Comm. on Energy and Commerce).

10. A. Leopold, A SANd County Almanac 237-64 (Ballantine ed. 1966). See also Wilkinson, Aldo Leopold and Western Water Law: Thinking Perpendicular to the Prior Appropriation Doctrine, 24 LAND \& WATER L. REV. 1 (1988).

11. The Report of the President's Commission, Americans Outdoors: The Legacy, The Challenge 168-69 (1987) [hereinafter Americans Outdoors Report]. In 1985, President Reagan created an advisory commission to review outdoor recreation in the United States, generally charging the Commission to examine public and private outdoor recreation opportunities, policies, and programs, including the land and resource base necessary to provide future outdoor recreation opportunities, and to make recommendations to ensure the future availability of outdoor recreation. Exec. Order No. 12,503, 3 C.F.R. 333 (1986).

12. H.R. 2379, 98th Cong., 1st Sess. (1983); S. 978, 98th Cong., 1st Sess., 130 Cong. REC. S291921 (daily ed. Mar. 20, 1984) (Chaffee Amendment No. 2807); H.R. 5162, 97th Cong., 2d Sess. (1982). See also Public Land Management Policy: Hearings on H.R. 999, H.R. 2379, H.R. 2014, H.R. 2107, Before the Subcomm. on Public Lands and the Subcomm. on National Parks of the House Comm. on Interior and Insular Affairs, 98th Cong., 1st \& 2d Sess. § 10 (1983-84); Public Land Management Policy: Hearings on H.R. 5162, H.R. 5552, H.R. 5973, and H.R. 5976 Before the Subcomm. on Public Lands and the Subcomm. on National Parks of the House Comm. on Interior and Insular Affairs, 97th Cong., 2d Sess. $\S 3$ (1982). See generally Keiter, On Protecting the National Parks From the External Threats Dilemma, 20 LAND \& WATER L. REv. 355 (1985); Coggins, Protecting the Wildlife Resources of National Parks From External Threats, 22 LAND \& WATER L. REV. 1 (1987).

13. See Federal Onshore Oil and Gas Leasing Reform Act of 1987, Pub. L. No. 100-203, 101 Stat. 1330-256 (amending $\S \S 187 \mathrm{a}, 187 \mathrm{~b}, 188,191,226$ and 16 U.S.C. $\$ 3148$; adding 30 U.S.C. $\$ \S 195,226-$ 3); Geothermal Steam Leasing Reform Act Amendments of 1988, 30 U.S.C.S. $\$ 1005$ (1988 Supp.). 
and sharing common species and interlocked natural features. ${ }^{14}$ With ninety percent of the region under federal ownership and nearly half of this officially preserved as park, wilderness, or wildlife refuge lands, the natural landscape remains remarkably undisturbed. Knowledgeable observers believe that the Yellowstone area constitutes the largest remaining intact natural ecosystem in the Earth's temperate zones. ${ }^{15}$ But man's presence and development pressure increasingly are being felt throughout the region and are taking a toll on the ecosystem, as evidenced by the plight of the grizzly bear. ${ }^{16}$ As Congress and others have recognized, the region's enormous ecological complexity is rivaled only by the extraordinary legal complexities governing land ownership patterns, planning systems, and management responsibilities. ${ }^{17}$

Bitter conflicts are now commonplace throughout the Yellowstone region. In many respects these controversies mirror the situation prevailing elsewhere on the public domain across the West; they are part of the long-standing struggle between competing preservationist and utilitarian factions, each interested in establishing its position as the dominant management philosophy. The basic issue today is whether traditional consumptive-use activities, such as oil and gas drilling, timber harvesting, and road building, are compatible with wilderness values and wildlife conservation goals. ${ }^{18}$ In the Yellowstone region, such questions have divided communities, ${ }^{19}$ and often find the

14. See Congressional Research Service, Library of Congress, Greater Yellowstone Ecosystem: An Analysis of Data Submitted By Federal and State Agencies, 99th Cong., 2d Sess. 4-7 (Comm. Print No. 6, Dec. 1986) [hereinafter CRS Ecosystem RePORT] (prepared for the Subcomm. on Public Lands and the Subcomm. on National Parks and Recreation of the House Comm. on Interior and Insular Affairs), and U.S. NAT'L PARK SERV., DEP'T OF THE INTERIOR \& U.S. Forest Serv., Dep't of Agric., an Aggregation of National Park and National Forest MANagement Plans 2-5 to -9 (1987) [hereinafter AggRegation Report] (prepared for Greater Yellowstone Coordinating Committee), for somewhat different descriptions of the Greater Yellowstone region. See also text at note 59, infra, for suggested definitions of the Greater Yellowstone Ecosystem.

15. Greater Yellowstone Ecosystem: Oversight Hearing Before the Subcomm. on Public Lands and the Subcomm. on National Parks and Recreation of the House Comm. on Interior and Insular Affairs, 99th Cong., Ist Sess. 434 (1985) [hereinafter Oversight Hearing] (written statement of Bob Anderson. Executive Director, Greater Yellowstone Coalition, quoting R. Reese (1984)); R. ReESE, Greater Yellowstone: The National Park and Adjacent Wildlands 13 (1984).

16. CRS EcOSYSTEM REPORT, supra note 14, at 19; U.S. FISH \& WILdlife SERV., Grizzly Bear Recovery Plan 1-6 (1982) [hereinafter Grizzly Bear Recovery Plan]. See generally T. MCNamee, The Grizzly Bear (1984).

17. Oversight Hearing, supra note 15, at 28-31; CRS ECOSYSTEM REPORT, supra note 14, at 4, 161. See also AMERICANS OUTDOORS REPORT, supra note 11, at 168-85.

18. See Oversight Hearing, supra note 15; CRS ECOSYSTEM REPORT, supra note 14, at 67-135. See generally R. REESE, supra note 15; Symposium, The Yellowstone Ecosystem, WESTERN WILDLANDS: A Natural Resource J., Fall 1986, at 1-26.

19. See Oversight Hearing, supra note 15, at 125-40. See also infra sections III.B. and IV.C. 
land management agencies themselves in disagreement. ${ }^{20}$ Local governing bodies, environmentalists, and industry groups have each exerted extreme pressure on local federal land managers, seeking to heel them to their particular vision of public land management policy. ${ }^{21}$ When this has failed, they have turned to the courts in one lawsuit after another, requesting judicial endorsement of their position. ${ }^{22}$ And at the same time, they have sought legislative assistance from Congress. ${ }^{23}$

It is the thesis of this article that the law represents a prominent-if yet somewhat overlooked-factor in the significant changes occurring in public land management today. Current law not only emphasizes environmental protection as a primary responsibility of the federal land management agencies, it also obligates land managers to view their responsibilities regionally, taking account of transboundary environmental impacts. This sets the stage for a new vision of public land management-a vision that bases management on ecosystem principles rather than on traditional boundary lines. ${ }^{24}$ In-

20. See, e.g., 2 U.S. Forest SERv., Dep't Of AGRic., Final. Environmental Impact StateMENT OF THE Gallatin National Forest Plan, VI-32 to -40 (1987) [hereinafter Gallatin ForEST PLAN FEIS] (Yellowstone National Park comments); id. at VI-83, -84 (U.S. Fish \& Wildife Service biological opinion). Cf. Sax \& Keiter, Glacier National Park and Its Neighbors: A Study of Federal Interagency Relations, 14 EcoloGy L.Q. 207 (1987).

21. See, e.g., Sierra Club, Yellowstone Under Siege: Oil and Gas leasing in the Greater Yellowstone Region (July 1986); The Wilderness Society, Management DirecTIONS FOR the NATIONAL Forests OF THE GREATER Yellowstone Ecosystem (Jan. 1987) [heteinafter Management Directions]; Wyoming heritage Found., White Paper: Wyoming's Federal LaNds (May 1987) [hereinafter Wyoming's Federal LaNDS]

22. See, e.g. Intermountain Forest Indus. Ass'n v. Lyng. 683 F. Supp. 1330 (D. Wyo. 1988); Park County Resource Council v. United States Dep't of Agric., 613 F. Supp. 1182 (D. Wyo. 1985), aff'd, 817 F.2d 609 (10th Cir. 1987); Conner v. Burford, 848 F.2d 1441 (9th Cir. 1988), cert. denied sub nom. Sun Exploration \& Prod. Co. v. Lujan, 109 S. Ct. 1121 (1989); Mountain States Legal Found. v. Hodel, 668 F. Supp. 144 (D. Wyo. 1987). See generally infra section IV.C.

23. Congress has held an oversight hearing on federal land management policy and practices in the Yellowstone region. Oversight Hearing, supra note 15; CRS ECOSYSTEM REPORT, supra note 14. See text at notes 307-10, infra, for a detailed description of this oversight hearing and the ensuing Congressional Research Service report. Congress recently passed legislation that will directly affect land management policies in the Yellowstone Region. See, e.g., 30 U.S.C.S. $§ 1005$ (1988 Supp.) (limiting geothermal development near national parks); 30 U.S.C. $\S 226(\mathrm{~h})$ (Supp. V 1987) (revising onshore oil and gas leasing). In recent years; Congress also has reviewed a plethora of legislative proposals that would permanently alter policies throughout the region. See, e.g., H.R. 1960, 99th Cong., 1st Sess. (1985) (Oil and Gas Leasing Reform Act); S. 1006 \& H.R. 2794, 100th Cong., 1st Sess. (1987) (Geothermal Leasing Reform Act); H.R. 3378, 100th Cong., 1st Sess. (1987) (wolf reintroduction into Yellowstone National Park).

24. See Ecosystem Management for Parks and Wilderness (J. Agee \& D. Johnson eds. 1988); Clark \& Zaunbrecher, The Greater Yellowstone Ecosystem: The Ecosystem Concept in Natural Resource Policy and Management, Renewable Resources J., Summer 1987, at 8-16; National Parks \& Conservation ass'n, National. Parks: From Vignettes to a Global View (1989) (a report from the Commission on Research and Resource Management Policy in the National Park System). See also The Ecosystem Concept in Nätural Resource Management (G. Van Dyne 
deed, this vision is emerging in the Greater Yellowstone region where federal land management agencies already acknowledge regional responsibilities in the area now frequently referred to as the Greater Yellowstone Ecosystem. ${ }^{25}$ Constituting an immense national treasure and a wildland system of international significance, Greater Yellowstone presents federal land managers with a paradigmatic setting for testing and implementing an ecosystem-based management philosophy. This article will review the role of the law in these developments and venture some tentative observations about the evolving concept of ecosystem management.

\section{Ecology and the Public Lands}

The term "ecosystem" has been defined as a "unit made up of all the living and nonliving components of a particular area that interact and exchange materials with each other."26 As a scientific concept, the ecosystem provides a comprehensive model for understanding and describing the complex relationships between the physical environment and biological species. Influenced by multiple environmental factors, ecosystems are constantly changing as they evolve from one successional stage to another. ${ }^{27}$ Historically, this process usually has involved gradual, incremental change produced by natural phenom-

ed. 1969); Caldwell, The Ecosystem as a Criterion for Public Land Policy, 10 Nat. Resources J. 203 (1970).

25. AgGregation Report, supra note 14, at vii-viii, 1-1 to -2. Environmentalists, wishing to emphasize the area's natural qualities and linkages, refer to the region as the "Greater Yellowstone Ecosystem." The federal land management agencies, however, have resisted adopting this term, preferring instead the term "Greater Yellowstone Area." Id. at 1-1. Industry groups, some local governing bodies, and other opponents have resisted any attempt to acknowledge the region as an entity. See G. Reynolds, Promise or Threat? a Study of "Greater Yellowstone Ecosystem" ManageMENT 123-24 (1987); WYOMING'S FEDERAL LANDS, supra note 21. Given the rhetorical power and metaphorical allure of the ecosystem concept, these differences are not unimportant or surprising. See infra text accompanying and following notes 41-42.

26. The Facts on File Dictionary of Biology 97 (1988). See also R. Ricklefs, The EconOMY OF NATURE 15 (2d ed. 1983). The nonliving or inorganic components of an ecosystem consist of such materials as air, water, and soil. These resources are each protected under existing laws. See, e.g.. Clean Air Act, 42 U.S.C.A. $\$ \S 7401-7642$ (1983 \& West Supp. 1989); Federal Water Pollution Control Act, 33 U.S.C. $\$ \S 1251-1387$ (1982 \& Supp. V 1987); National Forest Management Act, 16 U.S.C. $\S 1604(\mathrm{~g})(3)(\mathrm{E})(\mathrm{i})$ (1982) (insuring soil stability in the national forests). Moreover, in an area like Greater Yellowstone, which contains large expanses of park and wilderness lands, air and water resources generally receive a high level of legal protection under existing law. See Keiter, supra note 12, at 355, 378-81. It is beyond the scope of this article, however, to develop these legal principles in detail. See generally OUR Common LANDS, supra note 8; Ecosystem MANAgement for PARKS ANd WILDERNESS, supra note 24.

27. Ecosystems evolve naturally toward a climax state or community, which is usually the most complex community that can be supported in a given location and the most stable, i.e., capable of maintaining and replacing itself over time. See R. DASMANN, ENVIronmental Conservation 72 73 (5th ed. 1984). 
ena. ${ }^{28}$ In the modern world, however, man has greatly accelerated the rate of environmental change and upset longstanding evolutionary patterns-a fact illustrated by the increased rate at which species are now being lost to extinction. ${ }^{29}$ Ecosystem preservation, therefore, is a vitally important dimension of species conservation..$^{30}$ And biological diversity-itself an important stabilizing influence in nature-is a critical manifestation of the health of the ecosystem. ${ }^{31}$

Changes in the structure of even large, mature ecosystems can have severe, destabilizing environmental effects, destroying or fragmenting habitat, and thus isolating species in "habitat islands" inadequate to sustain viable populations. ${ }^{32}$ The initial impact will most likely be felt by sensitive, top-of-the-food-chain species-carnivores, such as wolves, bears, and bald eagles-which also are the species with the greatest natural impact on the ecosystem. ${ }^{33}$ While no single factor

28. These phenomena include climatic change, forest fires, floods, and avalanches, which have gradually reshaped the appearance of the earth's surface and its species. Displaced species usually have adapted to these periodic phenomena; rather than becoming extinct, they have occupied new niches in the ecosystem. O. Frankel \& M. Soule, Conservition and Evolution 22-30 (1981).

29. Id. at 25 (asserting that "[n]o other agent of environmental change is so devastating as man, or so thorough"); P. Ehrlich, A. Ehrlich \& J. Holdren, Ecoscience: Population, Resources, ENVIRONMENT 623 (1977). Because fire was so much a part of original evolutionary processes in the forests and grasslands, modern fire suppression efforts are widely regarded as one of man's most profound ecological impacts on the natural landscape. Leopold, Cain, Cottam, Garielson \& Kimball, Wildlife Manogement in the National Parks, in 28 Transactions of the N. AM. Wildife \& Nat. RESOURCES CONF. 29; 29-44 (1963) [hereinafter Leopold Report] (report of the Advisory Board on Wildlife Management appointed by Secretary of the Interior Udall); A. Chase, Playing GOD in Yellowstone: The Destruction of america's first National Park 63 (1986); T. Clark, Ecolocy of Jackson Hole, Wyoming: A Primer 64-70 (1981).

30. As Professor Frankel puts it: "[L]ong-term conservation is conceivable only within the confines of the ecosystem, which becomes the real target of conservation." Frankel, The Place of Management in Conservation, in Genetics and Conservation: A Reference for Managing Wild Animal and Plant Populations 2 (C. Schonewald-Cox, S. Chambers, B. MacBryde \& L. Thomas eds. 1983). See also May, The Evolution of Ecological Systems, ScI. AM., Sept. 1978, at 168 ("If a mature ecosystem is seriously disturbed, the distribution of relative abundances tends to revert to the level characteristic of early succession, dominated by a comparatively few species.").

31. K. Watt, Principles of Environmental SCience I40 (1973); The Wilderness Society, CONSER Ing Bjological Diversity in OUR National Forests 6-11 (1986). The term "biological diversity" is usually used to refer to the number of species-wildlife, plants, etc.-present in a given area. Biological diversity also refers to the ability of a species to perpetuate itself. In theory, species found in diverse locations with differing genetic characteristics are more likely to survive than species lacking genetic diversification. See infra note 50. See also Smith, The Endangered Species Act and Biological Conservation, 57 S. CAL. L. REV. 361, $369-82$ (1984) (arguing that biological diversity is instrumentally and intrinsically important to man); 6 ENCYCLOPEDIA BRITANNICA 281, 284 (15th ed. 1974).

32. According to conservation biologists, when members of one species are isolated from other members, there is no opportunity for genetic interchange within the species. Increased inbreeding inevitably results, and species tend to be less fit as a population and have less capacity to adapt to environmental changes. See generally R. Dasmann, WiLdlife BIology 169-74 (2d ed. 1981); O. Frankel \& M. SOULE, supra note 28, at 69-71, 132. See also infra note 34.

33. Frankel, supra note 30 , at 4, 10; O. Frankel \& M. Soule, supra note 28 , at 111-14. Signif- 
alone will ordinarily destabilize a large ecosystem, the aggregate impact of multiple human intrusions has markedly altered the earth's environment and influenced evolutionary patterns.

Framing public land policy in terms of ecosystem dynamics has profound implications for the relationship between the preserved and multiple-use lands. Even in the largest parks and wilderness areas, species have been lost and others, like the grizzly bear and bald eagle, face an uncertain future despite heroic efforts to promote their recovery. ${ }^{34}$ There is general agreement that these preserved lands-originally set aside for their scenic splendor without regard to ecological considerations-simply do not represent complete ecosystems capable independently of sustaining native wildlife populations. ${ }^{35}$ According to a recent study, most of the western North American national parks have lost wildlife species through extinction during this century because their legal boundaries do not embrace sufficient habitat to maintain viable populations. ${ }^{36}$

The preserved lands cannot be viewed in isolation; they represent only part of a larger ecosystem that includes adjacent multiple-use public lands, as well as other nearby landholdings. Although these lands sometimes complement each other as ecological entities, ${ }^{37}$ human activities such as mineral exploration, timber harvesting, and

cantly, biologists have documented that there is usually a time lag before the impact of environmental change is manifested in structural genetic changes within existing species. Frankel, supra note 30, at 11.

34. Conservation biologists have demonstrated that larger, more mature and structurally complex ecosystems generally support a wide diversity of species and can thus absorb otherwise destabilizing environmental changes. Ripley \& Lovejoy, Threatened and Endangered Species, in WILDLIFE IN America 365 (H. Brokaw ed. 1978) (published by Council on Environmental Quality); P. EHRL.ICH \& A. Ehrlich, Extinction: The Causes and Consequences of the Disappearance of Species 220-26 (1981); R. DASMANN, supra note 32, at 169-74; L. HARRIS, supra note 7, at 155. On the other hand, smaller ecosystems sustaining fewer species are more susceptible to such changes and usually experience a faster rate of extinction than their larger counterparts. L. HARRIS, supra note 7, at 82; May, supra note 30, at 168; Soule, Thresholds for Survival: Maintaining Fitness and Evolutionary Poteniial, in Conservation Biology: An Evolutionary-Ecological. Perspective 163-64 (M. Soule \& B. Wilcox eds. 1980); Frankel, supra note 30, at 4. Species in a larger ecosystem are therefore less likely to be impacted by human activities; population levels tend to be healthy and self regulating, set by genetic determinants and indigenous environmental factors. Frankel, supra note 30, at 6 (asserting that self regulation is "the most essential feature of nature conservation").

35. Soule, supra note 34, at 163; Frankel, Genetic Diversity, Ecosystem Conservation and Evolutionary Responsibility, in Ecology IN Practice $422-23$ (F. di Castri, F. Baker \& M. Hadley eds. 1984); Salwasser, Schonewald-Cox \& Baker, The Role of Inter-Agency Cooperation in Managing for Viable Populations, in Viable Populations for Conservation 160 (M. Soule ed. 1987) [hereinafter Viable Populations].

36. Newmark, supra note 7. See also L. HARRIS, supra note 7 , at 72 (noting species losses at Mt. Rainier National Park).

37. Park and wilderness lands generally represent mature ecosystems and provide habitat for many man-sensitive species, while forest lands that have been logged or grazed represent early to midsuccessional ecosystems and support different species. Viable Populations, supra note 35, at 159. 
grazing, as well as new road construction projects, often cause adverse environmental repercussions within the preserved lands and on migratory wildlife species. ${ }^{38}$ Given the dynamic nature of the ecosystem, there is no general scientific formula for defining the relationship between the preserved and multiple-use lands. It varies site-by-site and species-by-species, and it changes over time. Scientists are just beginning to understand how the component parts of an ecosystem interact and how sensitive they are to human disturbances. With such scientific uncertainty, it is not surprising that the public land management agencies-often encumbered with a history of interagency rivalry and an insular, boundary-based management tradition-find it difficult to agree on appropriate ecosystem management policies or strategies. Scientific complexity is not easily absorbed into an already complicated jurisdictional scheme, just as it is not easily accounted for in the law.

Yet there is an even more fundamental problem associated with using ecology as the guiding principle for managing the public domain. Public lands policy simply can not be defined solely in scientific terms. Man is now a dominant force in nature, and human interestseconomic, social, and political-must be accommodated. ${ }^{39}$ It is fine, perhaps even noble, to speak of the public lands as ecological entities where natural processes should be protected. But public lands also have played an important role in the social and economic development

38. CRS EcosySTEM REPORT, supra note 14, at 19, 48-53, 77-82. According to ecologists, perimeter disturbances such as these create an "edge effect" that drives species away from the disturbed lands and into the interior, causing a reduction in available habitat. Wilcox, Insular Ecology and Conservation, in Conservation Biology: An Evolutionary-Ecological Perspective 95-117 (M. Soule \& B. Wilcox eds. 1980); Lewin, Parks: How Big Is Big Enough?, 225 SCI. 611,612 (1984). This can be disastrous for species with specific habitat needs available only on the adjacent multiple-use lands, and for species with diverse habitat needs that depend on these lands as migration corridors to seasonal use areas. CRS ECOSYSTEM REPORT, supra note 14, at 46 (describing the impact of habitat fragmentation on the grizzly bear). Moreover, perimeter human disturbances can also prevent recolonization of park and wilderness areas by previously extirpated species. Even though the wolf has migrated into the Glacier National Park region from Canada, biologists do not expect it to naturally recolonize the Yellowstone area. For the wolf, the extensive development surrounding Yellowstone National Park has created a virtually impenetrable manmade barrier. Newmark, A Land-Bridge Island Perspective on Mammalian Extinctions in Western North American Parks, 325 NATURE, Jan. 1987, at 430, 432; Newmark, supra note 7, at 203; U.S. Fish \& WILdLIFE SERVICE IN COOPERATION WITH THE NORTHERN Rocky Mountain Wolf Recovery TEam, Northern Rocky MOUntain Wolf Recovery Plan 10-11 (1987) [hereinafter Wolf Recovery Plan].

39. R. DASMANN, supra note 27, at 354-58 (1984); Burch, Human Ecology and Environmental Management, in Ecosystem MANAgEMEnT for PARKS AND WILDERness, supra note 24, at 145; Miller, Biosphere Reserves in Concept and Practice, in Towards the BIosphere Reserve: EXPLoring Relationships Between Parks and Adjacent Lands 7-21 (Proceedings of an International Symposium, R. Scase \& C. Martinka eds. 1982); Wilkinson, Law and the American West: The Search for an Ethic of Place, 59 U. Colo. L. REv. 401, 404-10 (1988). See generally W. FIREY, MAN, MIND AND LAND (1960). 
of the nation and will certainly continue as a prominent influence on domestic affairs throughout the West. ${ }^{40}$ Too often, though, human interests have dictated management policy on the public lands without regard for the underlying ecological systems sustaining the natural resource base.

A new accommodation between man and the natural environment is required. This issue is now being addressed openly in the land management agencies and the political arena, where it ultimately may have to be resolved. With national values respecting the public lands and their role in the nation's culture continuing to evolve, the ecosystem concept may have its greatest impact at this social-political level. ${ }^{41}$ Already under current law, the land management agencies are beginning to acknowledge a responsibility to take account of the regional impact of their decisions, and they are cautiously undertaking some regional management initiatives. There is mounting evidence that the ecosystem concept, drawn upon scientific principles yet imbued with a powerful metaphorical allure, is reshaping the contemporary societal vision of the public lands. As we shall see, the concept has broadened the public land management policy dialogue to address the connection between the preserved and multiple-use lands-a subtle shift that is altering the balance of power among the competing factions. All of these forces are at work in the Yellowstone region, which is being cited as a model elsewhere on the public domain.

\section{Yellowstone AS AN ECOSYSTEM}

\section{A. The Natural Environment}

The Yellowstone country occupies a high plateau covered by dense stands of pine and fir trees. It is crisscrossed by several mountain ranges and interlaced by three major river systems-the Green, Yellowstone, and Snake-which headwater within the ecosystem. Geologically, the region was shaped by recent extensive volcanic activity, which accounts for its unique geothermal features as well as its dramatic mountain scenery. The idea of preserving such geothermal landmarks as Old Faithful Geyser and Mammoth Hot Springs prompted Congress in 1872 to establish Yellowstone as the world's first national park, ${ }^{42}$ while the grandeur of the rugged Teton mountain

40. P. Limerick, The Legacy of Conquest: The Unbroken Past of the American West 304 (1987); S. DANA \& S. FaIRFAX, supro note 1, at 110.

41. See S. Hays, supra note 5, at 99-136; J. Sax, Mountains Without Handrails: Reflections on the National Parks 103-05 (1980); P. Limerick, supra note 40, at 304. See also Sax, The Legitimacy of Collective Values: The Case of the Public Lands, 56 Colo. L. REV. 537 (1985); S. DANA \& S. FaIRFAX, supra note 1 , at 321-46.

42. R. Bartlett, Yellowstone: A Wilderness Besieged 1-7 (1985). The area's geology 
range inspired it to create neighboring Grand Teton National Park some sixty years later. ${ }^{43}$ Both inside and outside the parks, the region's natural features retain much of their original pristine character, and this scenic splendor annually attracts millions of visitors, giving rise to a tourism and recreation-based economy of singular importance to the area. ${ }^{44}$

These same natural resources are also otherwise commercially valuable. Geologists recently have concluded that the Overthrust Belt, another product of primeval volcanic rumblings, extends into the region and, judging from discoveries in southern Wyoming, may hold significant reservoirs of oil and natural gas. ${ }^{45}$ Along with the recent energy crises has come renewed interest in tapping into the geothermal aquifers, a move that could affect the park's geysers. ${ }^{46} \mathrm{~A}$ small logging industry traditionally has relied upon area forests for timber, and communities like Dubois and Afton, Wyoming, have grown dependent upon the timber industry for otherwise scarce jobs in an often depressed rural economy. Moreover, since the area was first settled, agricultural interests have looked to the lake and river systems as a

partially accounts for the park's ecologically unsound rectangular shape. Congress, intent on protecting these thermal curiosities, established the Park's boundaries simply by drawing straight lines around the prominent geothermal features, virtually ignoring other natural features and biological resources. A. RUNTE, supra note 7 , at 46,54 .

43. Id. at 118-27, 139-40. See generally R. Righter, Crucible For Conservation: The Creation of Grand Teton National Park (1982).

44. CRS ECOSYSTEM REPORT, supra note 14, at 111-35 (concluding that recreation supports more employment than any other activity in the Yellowstone region national forests); CASCADE HoLIStic Economic Consultants, Economic Database for the Greater Yel.lowstone Forests $15-21$ (1987) [hereinafter EcoNomic DATABASE] (noting that all Yellowstone region forest plans estimate that recreation is "worth far more than any other forest resource"). See also AGgREGATION REPORT, supra note 14, at 2-5 (chart 1).

45. See Mountain States Legal Foundation v. Andrus, 499 F. Supp. 383, 386-87 (D. Wyo 1980), for a brief description of the oil and gas potential of the Overthrust Belt area. Mineral exploration is generally forbidden by law in national parks as well as wilderness areas, unless the claim predated 1983. 16 U.S.C. $\$ 1133(d)(3)(1982)$. The BLM and the Forest Service effectively share jurisdictional authority over mineral activity on the nonwilderness forest lands. See infra note 253.

46. See A. ChASE, supra note 29 , at $285-86$ (describing the late 1970 s controversy over drilling for geothermal resources in the Island Park region of the Targhee National Forest, just west of Yellowstone Park); High Country News, June 22, 1987, at 12 (describing the recent controversy over proposed drilling by the Church Universal and Triumphant on the Royal Teton Ranch, just north of Gardiner, Montana, and Yellowstone's northern border and within nine miles of the famous Mammoth Hot Springs). See also Montana Dep't of Health \& Envtl. Sciences, Church Universal and Triumphant Final. Environmental Impact Statement (March 1989). On federal lands, jurisdiction over geothermal leasing and drilling is vested in the Secretary of the Interior under the Geothermal Steam Act of 1970, 30 U.S.C. $\$ \S 1001-1025$ (1982 \& Supp. V 1987). But the federal government has no jurisdictional authority over such resources on private lands, which explains why the Church Universal's proposal was reviewed by a Montana agency for compliance with state water quality standards. 
primary water source, and have advocated numerous water development proposals. ${ }^{47}$

Today wildlife shares top billing with the geyser system and the spectacular scenery as a primary resource and principal attraction in the Yellowstone region. All the major species present before white settlement, except the wolf, are still evident, including the grizzly bear, elk, bison, moose, bald eagle, peregrine falcon, and trumpeter swan. ${ }^{48}$ Most of the major species regularly range across park, forest, and private lands to meet their widely disparate seasonal habitat needs. But despite an extensive network of wild and near-wild lands, several species have not thrived-notably the grizzly bear, bald eagle, and peregrine falcon, which are listed on the endangered species registry. ${ }^{49}$ And despite the biological richness of the ecosystem, ${ }^{50}$ there is persistent debate over current population figures and distribution information for practically all the major species, as well as many of the less prominent ones. $^{51}$ Moreover, the Park Service and environmental organizations are promoting wolf reintroduction as a means of reestablishing a natural predator-prey balance within Yellowstone National Park. ${ }^{52}$

The "threatened" grizzly bear-a member of the so-called "charismatic megafauna"-occupies a unique position in the ecosystem. As

47. Numerous dams dot the Yellowstone landscape, including a prominent one at the foot of Jackson Lake in Grand Teton National Park. Other water development projects have been proposed regularly over the years and are renewed periodically, including proposals to construct dams inside park boundaries. R. BARTLETT, supra note 42 , at 347-58.

48. Other less prominent species are also important components of the biological system, both as a food base for the larger species and as indicators of environmental changes. For example, the cutthroat trout, which is found throughout the region's lakes and streams, provides a critically important food supply for the grizzly bear, bald eagle, and other species, and serves as an index to water quality. See CRS EcosySTEM REPORT, supra note 14, at 66. The pine marten, a little-known woods dweller, is dependent upon undisturbed old-growth forest, so its population numbers afford a measure of assurance that such habitat remains. U.S. Forest Serv., DeP'T of Agric., Shoshone National Forest LAND AND Resource Management Plan $11-47$ (1986) [hereinafter Shoshone Forest Plan]. See also text at notes 186-204, infra, discussing biological diversity legal requirements. See generally L. HARRIS, supra note 7.

49. 16 U.S.C. $\S 1533$ (1982); 50 C.F.R. $\$ 17.11$ at 74 (grizzly bear), 84 (bald eagle and peregrine falcon) (1986). See also CRS ECOSYSTEM REPORT, supra note 14, at 47-56, 59-64.

50. Biological richness refers to the total number of species present in the ecosystem, regardless of population numbers or the prospects for long-term survival. In contrast, biological diversity takes account of population locations and genetic characteristics, as well as population numbers. L. HARRIS, supra note 7, at 64. Thus, in a system like Yellowstone, the presence of a small number of grizzly bears assures biological richness, but the grizzly population may not be large enough to guarantee biological diversity sufficient to assure the species's survival.

51. A. Chase, supra note 29, at 80-81; D. Houston, The Northern Yellowstone Elk 23-6 (1982); Oversight Hearing, supra note 15, at 580-92 (statement of Dr. Tony Povilitis); F. Craighead, Track of THE GrizzLY 221-23 (1979).

52. High Country News, Nov. 23, 1987, at 10-15. See text at notes 174-82, infra, for a discussion of the wolf reintroduction question. 
a top-of-the-food-chain carnivore, it is heavily dependent upon other species; and given its diverse habitat needs and shy, man-sensitive nature, it requires large undisturbed areas for its survival. ${ }^{53}$ Consequently, agency officials generally acknowledge that bear population figures provide a telling measure of the overall condition of the ecosystem. Moreover, because the bear's status as a "threatened" species under the Endangered Species Act ${ }^{54}$ gives the U.S. Fish and Wildlife Service (FWS) a potential veto over any project involving federal lands, ${ }^{55}$ the grizzly emerges repeatedly as the focal point in disputes over controversial development proposals. Indeed, critics complain that the grizzly bear's legal clout and enormous notoriety dominate land use priorities throughout the region. ${ }^{56}$

The geophysical and biological complexity of the Yellowstone ecosystem makes establishing widely accepted ecological boundaries a nearly impossible task. In recent years, several ecosystem boundary definitions based upon such natural features as watershed contours, geological formations, vegetation characteristics, or grizzly bear range have been suggested. ${ }^{57}$ Although these natural and biological features are ecologically interconnected and represent important components of the ecosystem, the boundaries they define do not necessarily coincide. Nor, for that matter, is there widespread agreement on how to draw accurate boundaries around these resources-a fact highlighted by the continuing disagreement over grizzly bear habitat delineation, notwithstanding the intensive scrutiny the bear has received over the years. ${ }^{58}$ In short, the multidimensional nature of the ecosystem precludes any meaningful single-dimension definition, and its dynamic, evolutionary character makes it difficult to draw definitive ecological boundaries of any lasting significance. ${ }^{59}$

53. Grizzly Bear Recovery Plan, supra note 16, at 1-30; CRS Ecosystem RePort, supta note 14 , at $47-56$.

54. 16 U.S.C. $\$ \S 1531-1543$ (1982).

55. 16 U.S.C. $\$ 1536(a)(2)$. See notes 155 and $159-66$ infra and accompanying text for a more detailed discussion of the "no jeopardy" provision of the Endangered Species Act and the Act's relevance to controversies in the Greater Yellowstone region.

56. See infra text at notes $155-66,183-84$.

57. R. REESE, supra note 15, at 38-45 (1984); CRS ECOSYSTEM REPORT, supra note 14, at 29-33. See also Clark \& Zaunbrecher, supra note 24, at 8-16.

58. See D. Amato \& D. Whittemore, Status Report on Yellowstone Grizzly Bear 115-18 (Nov. 1988) (draft report prepared by Greater Yellowstone Coalition); Reid \& Gehman, A Common Sense Approach to Grizzly Bear Habitat Evaluation, Forest WATCH, Oct. 1987, at 9-15; T. MCNAMEE, supra note 16 , at $89-90$.

59. The recent Congressional Research Service report on the Greater Yellowstone Ecosystem adopts an avowedly arbitrary boundary definition, acknowledging the difficulty of setting precise, scientifically agreed-upon ecosystem boundaries. The CRS report relies upon climatic, vegetative, and topographical similarities, as well as legal jurisdictional boundaries, in setting its boundary. CRS ECOSYSTEM REPORT, supra note 14, at 4-5. Similarly, the recent Aggregation Report prepared by the 


\section{B. Interjurisdictional Conflict: Economics and the Environment}

Another obstacle to establishing concrete ecosystem boundaries in the Yellowstone region is the fragmented land ownership and management scheme. (See Map 1) Yellowstone and Grand Teton National Parks, encompassing more than 2.5 million acres (an area larger than Rhode Island and Delaware combined) and lying within three different states, form the core of the ecosystem. The parks are surrounded by seven national forests, ${ }^{60}$ most containing large segments of designated wilderness. ${ }^{61}$ (See Map 2) Three wildlife refuges are also located in the ecosystem. ${ }^{62}$ Although the park and wilderness lands are managed to preserve their natural conditions, major controversies are occurring over the appropriate level of human activity and intervention in this preserved environment. ${ }^{63}$. How these controversies are

Greater Yellowstone Coordinating Committee makes no attempt to define the area in natural terms; instead it relies upon existing jurisdictional boundaries. AGGREGATION REPORT, supra note 14, at v, 1 . 1 to -3 . It is not surprising, given these different approaches, that the CRS Report concludes that the Greater Yellowstone region encompasses approximately 14 million acres, while the Aggregation Report includes approximately 20 million acres in its definition of the region. The largest discrepancy between the two reports is the private lands acreage; the CRS Report includes approximately one million acres of private lands in its regional definition while the Aggregation Report includes five million acres.

60. These forests are: Bridger-Teton National Forest and Shoshone National Forest in Wyoming; Gallatin National Forest, Custer National Forest, and Beaverhead National Forest (which is located near, but not immediately adjacent to, Yellowstone National Park) in Montana; and the Caribou National Forest and Targhee National Forest in Idaho. These seven national forests are administratively accountable to three different regional Forest Service offices, located in Denver, Colorado, Missoula, Montana, and Ogden, Utah. 36 C.F.R. $\$ 200.2$ (1988). See Map 1, infra page 939, for an illustration of national park, national forest, and national wildlife refuge lands located in the Yellowstone region.

61. Over half of the national forest land surrounding the parks is designated as wilderness (approximately 3.7 million acres) or has been recommended for wilderness designation (approximately 2.45 million acres). CRS ECOSYSTEM REPORT, supra note 14, at 41; AGGREGATION RePORT, supra note 14, at 3-48 to -54 . Several of these wilderness areas abut park borders, creating an expansive, unbroken network of undisturbed park and forest lands. Other wilderness areas, however, are separated from this core area by multiple-use forest lands and private landholdings. See AGgregation REPORT, supra note 14, at 3-18 (map 9). See also text at notes 296-300, infra, for a discussion of the wilderness designation controversy over roadless forest lands located in the southern Gallatin Range.

62. The Fish and Wildlife Service is responsible for managing three wildlife refuges in the Greater Yellowstone region: the National Elk Refuge located just north of Jackson, Wyoming, which was created to provide critical winter habitat for the parks' elk, 16 U.S.C. $\$ 1673$ (1982); the Red Rock Lakes Refuge, which is located west of Yellowstone Park in Montana and provides winter habitat for the once-endangered trumpeter swan, 16 U.S.C. $\$ 1132$ (1982); and the Gray's Lake Refuge, located in Idaho southwest of Grand Teton National Park, which provides important habitat for the endangered whooping crane and other waterfowl, see L. RILEY \& W. RILEY, GuIDE TO THE NATIONAL WILDLIFE REFUGES 471 (1979). See also 16 U.S.C. $§ 668 d d(a)$ (1982) (charging the Secretary of the Interior with the responsibility of maintaining the wildlife refuge system "for the protection and conservation of fish and wildlife that are threatened with extinction"). The National Wildlife Refuge Administration Act generally prohibits most activities that would disturb the natural character of the refuges, but it specifcally sanctions mining and mineral leasing unless the lands are withdrawn, and it authorizes hunting within the refuges, subject to state game and fish laws. $I d$. $\S 668 \mathrm{dd}(\mathrm{c})$.

63. See infra note 87 (describing the Fishing Bridge campground controversy in Yellowstone Na- 
resolved could have significant ramifications for the substantive standards eventually attached to an ecosystem management scheme.

The region also encompasses more than five million acres of nonwilderness forest lands managed by the Forest Service under the multiple-use principle. Whether or not to open these lands-especially roadless lands located near the parks or wilderness areas and those that provide important wildlife habitat-to intensive development activities like logging and mineral exploration has been the focal point in recent clashes over land management policy. The Forest Service has found itself caught between opposing environmental and industry groups, each seeking to assert its own dominant use agenda for the forests, and each willing to turn to the courts as well as Congress for relief. Moreover, the Forest Service's policies have generated noticeable interagency discord; the Park Service and U.S. Fish and Wildlife Service are concerned that current timber harvesting programs and mineral development plans could adversely impact wildlife resources and habitat, as well as water quality. ${ }^{64}$ Further complicating resolution of these issues, Congress has not yet completed its wilderness designation process for Idaho and Montana, leaving the management status of the roadless, multiple-use forest lands in these states in limbo. ${ }^{65}$ (See Map 2)

State and private lands also are scattered throughout the forests bordering the national parks. ${ }^{66}$ Representing less than ten percent of the acreage in the region, these nonfederal lands are settled and devel-

tional Park) and text at notes $89-94$ (describing the current controversy over fire management policy). See generally A. Chase, supra note 29.

64. See, e.g., Gallatin Forest Plan FEIS, supra note 20, at VI-83, -84 (U.S. Fish \& Wildlife Service biological opinion); Letter to Brian Stout, Bridger-Teton National Forest Supervisor, from Robent Stewart, Dep't of the Interior Office of Environmental Project Review (Feb. 25, 1987) (commenting on the Bridger-Teton Draft Forest Plan). See also CRS EcosysTEM REPORT, supra note 14, at 78-79.

65. See text at notes 291-301, infra, for a description of the wilderness classification debates. See Map 2, infra page 940, for an illustration of existing wilderness areas and wilderness study areas in the Greater Yellowstone region, as well as the roadless federal lands inventoried by the Forest Service or the BLM for possible inclusion in the national wilderness system. The map also illustrates those public lands that conservation groups have proposed for wilderness designation and those areas regarded as critical ecological linkage lands.

66. While this article does not address the legal questions associated with private land use adjacent to the national parks and other federal lands, it is worth noting, to illustrate the jurisdictional fragmentation in the Yellowstone region, that these nonfederal lands are subject to the jurisdiction of three states (Idaho, Montana, and Wyoming) and numerous county and local governmental bodies, each with different zoning, land use, and environmental control laws. Reliable sources estimate that lands within the Greater Yellowstone region are under the jurisdictional authority of more than 30 different governmental or administrative bodies. Oversight Hearing, supra note 15, at 95. Moreover, Montana, Wyoming, and Idaho each faces serious economic problems, and state officials are vigorously promoting economic development programs while reviewing environmental standards to assure they do not discourage industrial growth. See, e.g., Wyoming Session Laws, 1987, ch. $82 \S 2$, ch. $175 \S 1$ (revising the Wyoming Industrial Development and Siting Act, Wyo. Stat. Ann. §§ 35-12-101 to-119). See 


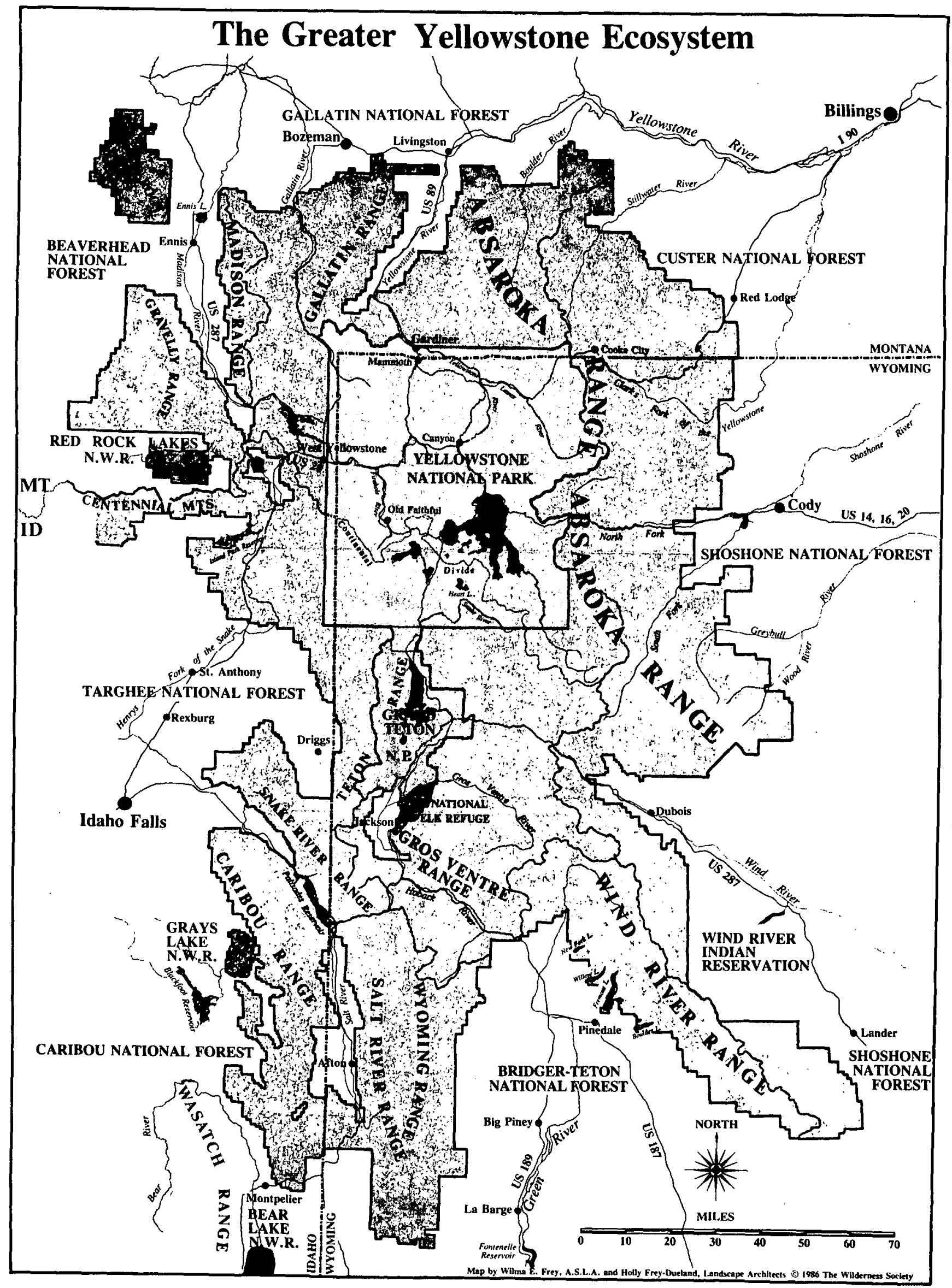

Reprinted with permission of The Wilderness Society.

Map 1. Federal Lands of the Greater Yellowstone Ecosystem

National Forest System
National Wildlife Refuge System
Private, state, or Bureau of Land Management (BLM) land, or Indian Reservation




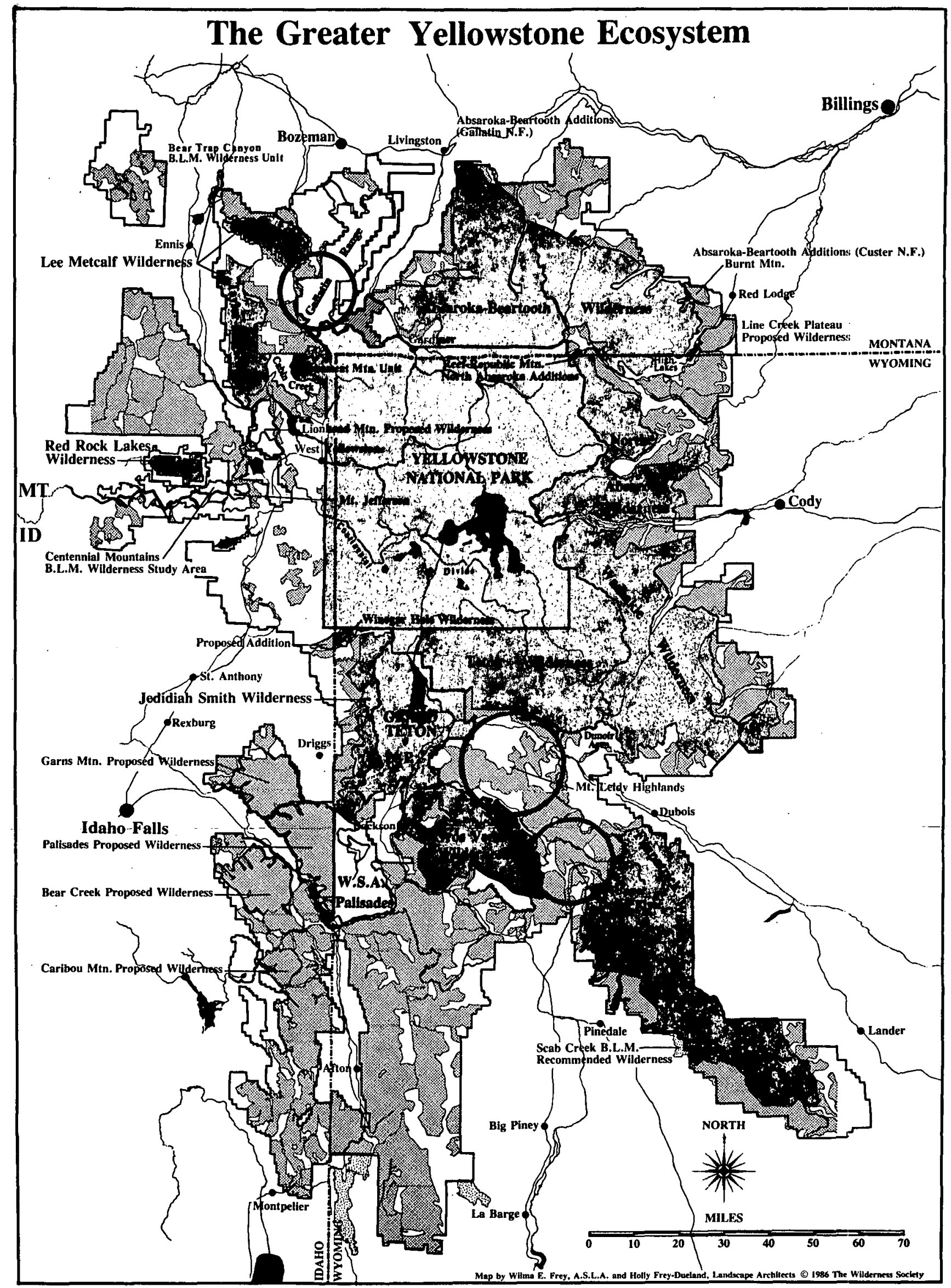

Reprinted with permission of The Wilderness Society.

\section{Map 2. Wild Lands of the Greater Yellowstone Ecosystem}

Protected Wild Lands:

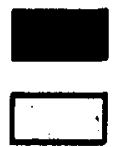

National Parks, Elk Reserve, and Wilderness designated by Congress (USFS, BLM, and USF\&WS)

Wilderness study and special management areas

Unprotected Wild Lands:

Roadless area inventoried by the Forest Service
Roadless area inventoried by the Bureau of Land Management

Conservationist Proposals:

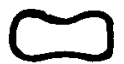

Proposed Wilderness

Linkage Area: Protection or restoration of area is needed to insure ecological integrity of the region. 
oped more intensively than are the public lands. ${ }^{67}$ Communities such as Jackson, West Yellowstone, Gardiner, Dubois, Cooke City, and Cody depend upon the surrounding federal lands for their economic sustenance, but there are striking differences among these towns and real conflicts over appropriate natural resource management strategies. While park gateway communities such as Jackson and West Yellowstone have embraced tourism as their dominant economic base, others like Dubois have been dependent upon the logging industry for jobs and economic growth. ${ }^{68}$ The states of Wyoming, Montana, and Idaho, which derive substantial tax revenues from natural resource development activity, ${ }^{69}$ also have economies that depend heavily upon tourism revenues; ${ }^{70}$ thus, state officials generally have avoided taking one side or another. ${ }^{71}$ There has been no consensus answer to the question of whether intensive, consumptive-use activities can coexist with the tourism-recreation industry that depends upon the natural scenic splendor of the area as its primary attraction. ${ }^{72}$ Indeed, finding common ground in this setting has not proven an easy task.

generally Sax, supra note 3; Comment, State Participation in Federal Policy Making for the Yellowstone Ecosystem: A Meaningful Solution or Business as Usual?, 21 LAND \& WATER L. REV. 397 (1986).

67. CRS Ecosystem REPORT, supra note 14, at 31-34. Notably, these nonfederal lands account for a disproportionate number of unexplained grizzly bear mortalities. Id. at 50. And the Yellowstone geyser system presently faces its most serious threat from a proposed geothermal development project on private ranch lands north of the park. See supra note 46.

68. See Oversight Hearing, supra note 15, at 12-35; U.S. Forest SERV., Dep'T of AGRIC., Bridger-Teton National forest land and Resource Management Plan Draft EnvironMENTAL IMPACT STATEMENT II-96 to -97 (1987) [hereinafter Bridger-Teton DEIS]; Gallatin Forest Plan FEIS, supra note 20, at III-5 to -12. See also U.S. Forest SERV., DeP't of Agric., Status of Forest Planning for Bridger-Teton National Forest 2 (rev. draft Dec. 15, 1987) (noting that among communities in the Bridger-Teton area, Pinedale and Jackson rely upon recreation and tourism, Dubois and Afton rely upon timber harvesting, and Big Piney and Kemmerer look to oil, gas, and ranching to support their local economies).

69. See, e.g., 30 U.S.C. $\$ 191$ (1982) (granting the states $50 \%$ of the revenues from oil and gas leases on the public lands); 16 U.S.C. $\S 500$ (1982) (granting local counties $25 \%$ of the stumpage sales from timber harvesting on the national forests). See also Payment in Lieu of Taxes Act, 31 U.S.C. $\$ \S 6901-6906$ (1982) (providing for a minimum payment of 75 cents per acre of federal land to local governments, regardless of development revenues).

70. AGGREGATION REPORT, supro note 14, at 2-6 to -7. Significantly, in Wyoming and Montana, tourism is now firmly ensconced as a major revenue-producing activity in each state's economy. See CRS ECOSYSTEM REPORT, supra note 14, at 68-69; Oversight Hearing, supra note 15, at 441-42. See also Tourism Promotion, Western Wildlands, Summer 1987, at 2-21; N.Y. Times, Apr. 16, 1989, $\S 6$ (Magazine), at 64; Tourism Outlook Upbeat, Billings (Montana) Gazette, Apr. 20, 1986, at F3.

71. But see Casper Star Trib., Feb. 10, 1989, at B1, and Feb. 25, 1989, at Al (Wyoming, Montana, and Idaho governors join other Western governors in urging Supreme Court to overturn the ruling in Conner v. Burford, 848 F.2d 1441 (9th Cir. 1988), cert. denied sub nom. Sun Exploration \& Prod. Co. v. Lujan, 109 S. Ct. 112 (1989)).

72. Notably, the controversies not only pit the traditional extractive industries against a coalition of environmentalists and tourism-recreation proponents, but environmental groups have found themselves at odds with both of the other factions. For example, in the case of the proposed Ski Yellowstone project near West Yellowstone, environmental groups have clashed with the recreational development 


\section{The Cumulative Impact Problem}

The ecological impact of intensive consumptive use activities on largely undisturbed forest lands can be significant, with repercussions also directly affecting adjacent preserved lands. ${ }^{73}$ Logging and mineral exploration projects bring people, roads, and heavy equipment into previously inaccessible areas, even if only temporarily. ${ }^{74}$ Such disturbances inevitably impact wildlife habitat by eliminating cover and driving man-sensitive species, including grizzly bears and elk, from the surrounding forest. They can affect water quality by increasing stream sedimentation, thus impairing traditional trout spawning locations. Clearcutting, drilling rigs, and new roads also dramatically alter the aesthetic appearance of the landscape. Moreover, there is now real concern that exploratory drilling on the perimeter of Yellowstone National Park could directly affect the Park's geyser system. ${ }^{75}$ But according to the Congressional Research Service, road construction represents the major, single threat to the Yellowstone region. ${ }^{76}$ By opening the forests to increased human access, more roads result in more human-wildlife contact and increased poaching opportunities. Roads can also fragment important wildlife habitat.

The real threat to the ecological integrity of the Yellowstone region, however, arises from the cumulative impact of development on the multiple-use forest lands and private property outside the park and wilderness boundaries. The Yellowstone ecosystem is neither large enough nor resilient enough to absorb the combined impact of multiple development projects. In the West Yellowstone area, for example, numerous timber sales, the proposed Ski Yellowstone complex, and accompanying subdivision construction collectively could create a "wall of development," separating the Park from surrounding wilder-

promoters. See infra note 165. And the Fishing Bridge controversy pits Cody tourism business interests squarely against environmentalists. See infra note 87. Similar schisms are evident over the question of an appropriate park and wilderness fire management policy for the region. See infra text at notes $89-94$.

73. See supra notes $32-38$ and accompanying text.

74. Impacts from oil and gas drilling operations may be temporary (assuming a dry hole); other impacts, for instance, from logging, might be regulated by contractual stipulations. But the roads that invariably are constructed to the project sites provide permanent access into the forest long after the initial development ceases. Road closures, when employed, sometimes limit further motorized access, but closures have not always proven effective, and they do not deter foot and nonvehicle access to the area. CRS EcosySTEM REPORT, supra note 14, at 70; SIERRA Club, supra note 21, at 11

75. Oversight Hearing, supra note 15, at 61; GALLATIN Forest PLAN FEIS, supra note 20, at VI39, -40 (Yellowstone National Park comments); Memorandum to Lorraine Mintzmyer, Regional NPS Director, from Irving Friedman, U.S. Geological Survey Research Geochemist (Jan. 13, 1986) (available from author).

76. CRS ECOSYSTEM REPORT, supra note 14 , at 9. 
ness lands and cutting off important wildlife migration corridors. ${ }^{77}$ While elk and grizzly bears may successfully navigate isolated clearcuts and roads, they are not likely to cross lands honeycombed with roads and vacation homes. Similarly, in the Mt. Leidy Highlands region of the Bridger-Teton National Forest, scheduled timber harvests, oil and gas exploration activities, and road construction could drive wildlife from these lands and further disrupt traditional migration patterns. ${ }^{78}$ When these impacts are aggregated throughout the region, there is a very real prospect of significant habitat loss, isolation of wildlife populations, and ultimately a reduction in species diversity. Plainly, the problem of cumulative impacts can be resolved only by interagency coordination efforts and a substantive commitment to integrate ecological principles into management policies.

\section{LaW and Ecology: Management Under Conflicting PHILOSOPHIES}

Public land law traditionally has accorded federal land management agencies virtually unlimited discretion in administering their lands, and it has treated the boundary line as sacrosanct in defining the realm of agency authority. Neither of these legal principles, however, takes account of the ecosystem as an integrated entity subject to its own natural order. Nevertheless, using existing statutory mandates and as-yet uninterpreted or unenforced statutory provisions, it is possible to construct legal arguments that support the concept of ecosystem management on the public lands. Indeed, the courts, invoking laws such as the Endangered Species Act (ESA) ${ }^{79}$ and the National Environmental Policy Act (NEPA), ${ }^{80}$ have made species preservation a high priority concern among the land management agencies and have saddled them with significant procedural obligations for environmental protection. In several important respects, then, unbridled discretion is no longer the rule on the public domain, the boundary line has been breached, and the ecosystem legitimized as a relevant management concern.

77. CRS ECOSYSTEM REPORT, supra note 14 , at 155-58.

78. See U.S. Forest Serv., Dep't of Agric., Draft Final Bridger-Teton Land and Resource Management Plan 70-71, A-16 (1989) [hereinafter Draft Final Bridger-Teton Forest Plan]; U.S. Forest Serv. Dep't of Agric., Draft Final Bridger-Teton land and Resource Management Plan Environmental Impact Statement 3-145, -146 (1989) [hereinafter Draft Final Bridger-Teton Forest Plan EIS]. These publications are described as "Draft Final" because the references are to advance copies of the final documents, which are still subject to minor editorial changes before being released to the public. See also MANAGEMENT Directions, supra note 21 , at $6-7$.

79. 16 U.S.C. $\$ \S 1531-1543$ (1982).

80. 42 U.S.C. $\$ \S 4321-4370$ (1982). 


\section{A. The Preserved Lands: Restraint Beyond the Border?}

The concept of a Greater Yellowstone Ecosystem is built around the core park and wilderness lands, which Congress has mandated are to be preserved in their natural state. As the theory goes, if these lands are inviolate, then the Forest Service and others responsible for adjacent lands must adjust their management philosophy accordingly. The strength of this strategy is that it capitalizes upon Yellowstone National Park's high national visibility and Congress's enduring political commitment to the park as a symbol of the nation's wilderness heritage. But this strategy raises two important legal questions, both fundamental to the notion of ecosystem management. First, do the organic park and wilderness laws insure that natural values will always prevail on these "preserved" lands in case of conflict with other human interests? Second, does the organic preservation legislation have any extraterritorial application and thus provide meaningful protection for park and wilderness lands against environmentally threatening activities occurring on adjacent lands?

\section{The National Parks}

Yellowstone and Grand Teton parks are managed by the National Park Service under the National Parks Organic Act to conserve scenery, natural and historic objects, and wildlife, and to provide for public enjoyment, while insuring they are left "unimpaired for the enjoyment of future generations." 81 In recent years the Park Service has sought to reconcile the conflict between its preservation and public-use responsibilities by emphasizing resource protection over visitor access, a position that squares neatly with the agency's obligation to future generations. ${ }^{82}$ Relying upon its expansive regulatory authority over its own lands, ${ }^{83}$ the Park Service has adopted a resource management

81. 16 U.S.C. $\$ 1$ (1982). See generally Lemons \& Stout, A Reinterpretation of National Park Legislation, 15 ENVTL. L. 41 (1984).

82. See, e.g., Nat'l Park Serv., Dep't of the Interior, Twelve Point Management Plan (1986); Yellowstone Nat'l Park, Natural Resources Management Plan and EnviRONMENTAL AsSessment 7 (1982) [hereinafter Yellowstone MaNagement Plan]. See also Lemons \& Stout, supra note 81, at 65; Lockhart, External Park Threats and Interior's Limits: The Need for an Independent National Park Service, in OUR COMmON LANDS, supra note 8, at 30-34. For example, Yellowstone park officials recently have rejected requests to open park rivers to recreational boating, fearing that it would disturb wildlife and fragile riverbank vegetation. YelLowstonE NAT'L PARK, DEP'T OF THE INTERIOR, BOATING ON YELlOWSTONE'S RIVERS: AN ANALYSIS AND ASSESSMENT (Nov. 1986) (draft report). But see NAt'l Park Serv., U.S. Dep't of the Interior, Final Environmental Impact Statement Development Concept Plan, Fishing Bridge Developed AREA: YellowSTONE (1988) [hereinafter FISHING BRIDGE FEIS] (authorizing retention of a campground in the face of evidence that its location is harmful to Yellowstone's grizzly population).

83. 16 U.S.C. $\$ 3$ (1982). The courts consistently have upheld Park Service regulations limiting public access or safeguarding important resources. See, e.g., National Rifle Ass'n v. Potter, 628 F. 
philosophy based upon the 1963 Leopold Report, which recommended that "a national park should represent a vignette of primitive America," or a place where natural biological processes prevail without human intervention. ${ }^{84}$ In Yellowstone and elsewhere, Park Service officials essentially are adhering to a "laissez faire" management regime predicated upon ecological principles. ${ }^{85}$

Critics charge, however, that natural process management is impossible within the limited and arbitrary confines of the parks, citing as evidence the precipitous decline in the grizzly bear population when Yellowstone closed its garbage dumps and elk overpopulation on the Yellowstone northern range. ${ }^{86}$ They also note that encroachment on adjacent lands necessarily constrains the Park Service's wildlife management options. Indeed, the Park Service has not consistently followed a strict natural process management approach. Nor, as the recent Fishing Bridge campground controversy proved, ${ }^{87}$ is it clear

Supp. 903 (D.D.C. 1986); Organized Fishermen v. Watt, 590 F. Supp. 805 (S.D. Fla. 1984), aff'd, 775 F. 2d 1544 (5th Cir. 1985); Free Enterprise Canoe Renters Ass'n. v. Watt, 711 F.2d 852 (8th Cir. 1983); Eiseman v Andrus, 433 F. Supp. 1103 (D. Ariz. 1977), aff'd, 608 F.2d 1250 (9th Cir. 1979), cert. denied, 446 U.S. 982 (1980); United States v. Brown, 552 F.2d 817 (8th Cir.), cert. denied, 431 U.S. 949 (1977); see also 36 C.F.R. $§ 1.5$ (1988).

84. Leopold Report, supra note 29, at 31-32. See A. RUNTE, supra note 7, at 197-98, for a description what prompted the Leopold Report.

85. Yellowstone Management Plan, supra note 82, at 60-62, 81-97. Although the Park Service previously suppressed natural fires, sanctioned wildlife feeding, and culled big game herds, they no longer do any of these things. For example, the Park Service recently decided not to intervene when Yellowstone's northern bighorn sheep population contracted the pink eye disease, causing many to fall to their deaths from the steep cliffs that are their homes. Though medication might have arrested the disease, park officials concluded that such intervention was inconsistent with their natural management policy. See A. ChASE, supra note 29, at 81-82.

86. F. Craighead, supra note 51, at 207-08 (alleging Park Service mismanagement of the grizzly bear by suddenly closing garbage dumps where the bears traditionally had fed); A. CHASE, supro note 29, at $77-81$ (charging the Park Service with permitting the elk population to proliferate far beyond the northern range's historic carrying capacity). But see D. HousToN, supra note 51, at 23-25 (asserting that current elk population numbers are consistent with their historic levels).

87. The Fishing Bridge campground controversy, which has spawned one lawsuit and active political intervention by the Wyoming congressional delegation, has been widely regarded as a symbolic test case of the Park Service's commitment to its "nature first" philosophy. The dispute concerns whether the 65-year old campground complex, which is located in prime grizzly bear habitat on Yellowstone Lake, should be removed to restore the area to its original condition. Although the Park Service once planned to dismantle the facility, it has since decided upon a modified plan retaining part of the campground. See generally FiShING BRIDGE FEIS, supra note 82. This "compromise" apparently was conceived to placate local political interests concerned that closing the campground might deter tourists from entering the Park via the gateway community of Cody, Wyoming. In National Wildlife Federation v. National Park Service, 669 F. Supp. 384 (D. Wyo. 1987), the Park Service successfully defended its decision against charges that opening the campground violated its Organic Act preservation responsibilities as well as Endangered Species Act strictures. Plainly, the court was reluctant to second-guess the Park Service's internal management decisions; its ruling effectively gave the agency sufficient discretion to accommodate visitor use, even at some expense to the natural environment. See also infra notes $166-67$ and accompanying text. 
that Yellowstone officials can implement fully a management philosophy dominated by an exclusive concern for nature. ${ }^{88}$

The Park Service's natural process management policy has been put to a stern test in the aftermath of the massive summer 1988 fires. In 1972, following the Leopold Report recommendations, ${ }^{89}$ the Park Service adopted a "natural burn" policy, fighting only those naturally caused fires that threatened lives or property. ${ }^{90}$ The policy worked without notable incident until the summer of 1988 when drought conditions and high winds caused wildfires throughout Yellowstone Park and surrounding wilderness areas to burn out of control-a phenomenon that graphically illustrated the ecological interconnectedness of the Greater Yellowstone region. ${ }^{91}$ Park officials, scientists, and environmentalists contend that the beneficial ecological effects of the fires-improved wildlife habitat, forest regeneration, and the likeoutweigh the adverse aesthetic impacts and will significantly improve the ecosystem in the long term. Many local citizens, however, smarting from fire-related losses, charge the Park Service with negligence and have aadvocated a change in policy. ${ }^{92}$ Congress has held hear-

88. The Organic Act specifically sanctions some intervention by the Park Service against nature; it provides that park officials may remove wildlife, plants, and timber, and control insects. 16 U.S.C. $\S 3$ (1982). Not only may such intervention help conserve park scenery and enhance visitor use, it also is sometimes necessary to avoid legal liability for harm to visitors or property. See Mandel v. United States, 793 F.2d 964 (8th Cir. 1986). Cf. Rayonier, Inc. v. United States, 352 U.S. 315 (1957); Coe v. United States, 502 F. Supp. 881 (D. Ore. 1980). See also 16 U.S.C. $\$ 673($ c) (1982) (sanctioning an annual elk hunt in Grand Teton National Park); A. RUNTE, supra note 7, at 205-07 (describing the Park Service's natural and controlled fire burning program).

89. Leopold Report, supra note 29.

90. Yellowstone Management Plan, supra note 82, at 60-62. Previously the agency had adhered to a strict fire suppression policy, extinguishing every fire within the park regardless of whether it was caused by natural elements or was manmade. See A. RUNTE, supra note 7, at 197-208. Similar policy changes were made by the Forest Service in its handling of fire within designated wilderness areas. BRIDGER-TeTON DEIS, supra note 68, at IV-22. See also AGGREGATION REPORT, supra note 14 , at 3-88 to -93 .

91. Despite a midsummer decision authorizing aggressive firefighting on all fronts, the fires ultimately affected nearly 50\% of the Park's acreage and considerable acreage in the surrounding national forests. Approximately 1.1 million acres of the 2.2-million acre Park were affected by the fires, but only $20 \%$ of the affected acreage was severely burned; the remaining acreage was only slightly affected by the fires or was unburned but located within the fire perimeter. The Denver Post, Oct. 11, 1988, at 1A. Fire also touched more than 0.5 million acres of forest land outside the Park. Casper Star Trib., Sept. 25, 1988, at B1. For more specific information, see Greater Yellowstone Post-Fire Resource assessment Comm., Burned area Survey team, Preliminary Burned Area Survey of Yellowstone National. Park and Adjoining National Forests (Dec. 1988). See generally G. Wuerthner, Yellowstone and The Fires of Change (1988); Yellowstone Nat'l Park, Nat'l Park Serv., The Yellowstone Fires: A Primer on the 1988 Fire Season (Oct. 1, 1988).

92. Casper Star Trib., Aug. 29, 1988, at B1; id., Sept. 1, 1988, at A1; id., Sept. 6, 1988, at B1. Local businesses and government officials have sought federal economic assistance and also threatened legal action to recoup lost revenues. Moreover, with the widespread publicity that accompanied the fires, they are concerned that tourists will stay away from the Park in the future. Federal and state government officials, however, are promoting tourism for the 1989 summer season and beyond. 
ings reviewing the policy, ${ }^{93}$ and the Department of the Interior has conducted its own administrative review, which recommended retaining the basic policy with some modifications. ${ }^{94}$ Congress now appears unlikely to adopt legislation revising the policy. The Park Service's apparent success in defending its "natural burn" policy reflects a profound evolution in public attitudes about natural resources management and the role of ecological processes. Moreover, it suggests that the public has the ability to understand the scientific complexities and administrative strategies necessary to implement ecosystem-based management policies.

Internal park management controversies, such as those involving the fire policy and Fishing Bridge, also offer a significant lesson about the institutional constraints that the Park Service faces under current law, and the implications of these constraints for developing an ecosystem management strategy focused on the national parks. Despite its preservationist mandate and its commitment to a natural process policy, the Park Service has the legal authority under its Organic Act $^{95}$ to deviate from these goals to accommodate other human interests, so long as it does not impair park resources or run afoul of laws such as the Endangered Species Act. Not surprisingly, the Park Service has seldom been able or willing to ignore its neighbors and other human concerns. Indeed, laws such as NEPA virtually require the Park Service to address the social and economic, as well as environmental, ramifications that its decisions will have within the parks and beyond their borders. With winter use rapidly escalating in Yellowstone and Grand Teton National Parks, Park Service officials again are confronting the same dilemma as they develop a winter-use management plan: What level of development and type of recreational experience is appropriate in the park winter environment, given the level of visitor interest, the need to protect wildlife, and the growing winter tourism

93. Current Fire Management Policies: Joint Hearing Before the Subcomm. on Public Lands. Na. tional Parks, and Forests of the Senate Comm. on Energy and Natural Resources and the Subcomm. on Conservation and Forestry of the Senate Comm. on Agriculture, Nutrition, and Forestry, 100th Cong., 2d Sess. (1988); The Economic Impact of Fires in Yellowstone National Park and Western Montana on Small Business: Hearing Before the Subcomm. on Rural Economy and Family Farming of the Senate Comm. on Small Business, 100th Cong., 2d Sess. (1988).

94. An interagency Fire Management Policy Review Team, which included Park Service and Forest Service representatives, has endorsed continuation of the current "natural burn" policy, with some modifications in management standards and greater public involvement opportunities. FIRE Management Policy Review Team, Dep't of the interior \& Dep't of Agric., Report on Fire Management Policy (Dec. 14, 1988). Both agencies have temporarily suspended the policy until these modifications can be implemented. The Denver Post, June 2, 1989, at 1B; Casper Star Trib., June 2, 1989, at $1 \mathrm{~B}$.

95. 16 U.S.C. $\S \S 4,3$ (1982). See supra note 88. 
market in surrounding communities? ${ }^{96}$ In effect, each of these cases reaffirms the inherent tension between ecologically based management standards and potentially conflicting economic interests and aesthetic predilections-a tension rooted in fundamental value differences over the appropriate relationship between man and nature that ultimately may have to be resolved in a political forum.

The ecosystem concept teaches that the natural integrity of the parks also depends upon what occurs on adjacent lands. But does the Park Service enjoy any authority under the Organic Act over adjoining lands when park resources are threatened by activities occurring on these lands? The 1978 Organic Act amendments ${ }^{97}$ impose a clear legal duty on the Secretary of the Interior to protect park resources against threatening activities arising on adjacent lands-a requirement that effectively endorses a regional management perspective. This socalled Redwood Park amendment provides that "the protection, management and administration of [national parks] shall be conducted in light of the high public value and integrity of the National Park System and shall not be exercised in derogation of the values and purposes for which these various areas have been established."98 While the amendment is not a model of drafting clarity, ${ }^{99}$ the courts have

96. Statistics show Yellowstone National Park winter visitation growing steadily at a five percent annual rate during recent years, and now exceeding 100,000 visitors per season. Statement for Management, Yellowstone National Park 36 (Aug. 1986); Nat'l PARK SERV., U.S. DeP'T OF INTERIOR, Newsletter-Joint Winter Use Plan Issues, Yellowstone National Park, Grand Teton National. Park, John D. Rockefeller, JR. Memorial Parkway (Mar. 1989) (hereinafter NewSLetTer-Joint Winter USE Plan]. The economic importance of park winter tourism opportunities to surrounding communities is illustrated in West Yellowstone, Montana, where $85-90 \%$ of the town's winter economy is now attributed to snowmobile activity, principally occurring in Yellowstone National Park. Casper Star Trib., Feb. 22, 1988, at B1. Recognizing the regional implications of park winter use, the Park Service is developing a joint plan for all of its lands in the Yellowstone area. Major issues to be addressed include: the level and location of snowmobile use, including snowmobile access to Grand Teton National Park to accommodate a proposed transmountain snowmobile trail; whether additional lodging facilities should be opened in Yellowstone or whether current facilities should be expanded; and whether to plow park roads to facilitate visitor access. See NewSLETTER-Joint WINTER USE Plan, supra. See also infra text at notes 391-92.

97. Pub. L. No. 95-250, 92 Stat. 166 (1978) (codified at 16 U.S.C. $\$ \S 1 a-1,79 b-79 q(1982)$ ).

98. 16 U.S.C. $\$ 1 \mathrm{a}-1$ (1982) (emphasis added). The amendment was triggered by the Redwood National Park controversy, an affair that dramatically demonstrated the ecological relationship between the Park and adjacent upstream lands. See Hudson, Sierra Club v. Department of Interior: The Fight to Preserve the Redwood National Park, 7 Ecology L.Q. 781 (1979).

99. Specifically, the $§ 1 \mathrm{a}-1$ amendment contains an "exceptions" clause, relieving the Park Service of any obligation to protect park resources when Congress has "directly or specifically" authorized the adjacent activity. The question is whether this "exceptions" clause should be read broadly (in which case it would relieve the Park Service of any obligation to protect park resources whenever the threatening activity arose on multiple-use lands) or narrowly (in which case the Park Service's protection duty would apply unless Congress had specifically sanctioned the particular project). The language and legislative history of the provision, as well as judicial precedent, support a narrow construction of the clause. See Keiter, supra note 12, at 355, 369-75; Lockhart, supra note 82, at 30-36. The author of the 
interpreted it as imposing an absolute legal duty on the Secretary of the Interior to protect park resources from environmental degradation. ${ }^{100}$ Moreover, the courts have consistently sustained the Secretary's authority under the Organic Act to promulgate regulations limiting incompatible activities on nonfederal lands adjacent to the parks. ${ }^{101}$ It is not clear, however, that the Secretary enjoys the same regulatory authority over activities on adjacent lands managed by other federal agencies.

Because Congress only rarely has granted the Park Service any express power over adjacent lands, ${ }^{102}$ the courts have been reluctant to read the amendment as imposing any affirmative legal obligations on the Secretary in his dealings with park neighbors. In essence, the courts have concluded that judicial intervention under an abuse of discretion standard is appropriate only under exceptional circumstances. ${ }^{103}$ In Sierra Club v. Andrus, ${ }^{104}$ for example, the court ruled that the Secretary of the Interior did not act unreasonably when he refused to litigate federal reserved water rights claims in waters flowing through Grand Canyon National Park. ${ }^{105}$ In Clark v. Community for Creative Non Violence, ${ }^{106}$ the Supreme Court confirmed this posi-

provision certainly intended it to create a public trust obligation on the Park Service (and on the Secretary of the Interior), thus reaffirming the Redwood holding. Letter from James D. Webb to Professor Robert B. Keiter (Sept. 17, 1986) (available from author) (Mr. Webb served as Associate Solicitor for Conservation and Wildlife in the Department of the Interior during the drafting of this legislation). But see U.S. General Accounting Office, Limited Progress Made in Documenting and Mitigating Threats to the Parks 51 -57 (1987) (report to the Chairman, Subcomm. on National Parks and Recreation of the House Comm. on Interior and Insular Affairs).

100. Sierra Club v. Andrus, 487 F. Supp. 443 (D.D.C. 1980) (holding that the $\S 1$ la-1 amendment imposes an absolute legal duty on the Secretary of the Interior to protect park resources). See also National Rifle Ass'n v. Potter, 628 F. Supp. 903 (D.D.C. 1985); Keiter, supna note 12, at 375.

101. Cf. Free Enterprise Canoe Renters Ass'n v. Watt, 711 F.2d 852 (8th Cir. 1983); United States v. Brown 552 F.2d 817 (8th Cir.) (sustaining Park Service regulations limiting activities on state and private land located within park boundaries), cert. denied, 431 U.S. 949 (1977); North Dakota v. United States, 460 U.S. 300 (1983) (sustaining the authority of the Secretary of the Interior to regulate private land on the basis of an easement to the federal government protecting wildlife habitat). See also Comment, Protecting National Parks from Developments Beyond Their Borders, 132 U. PA. L. REV. 1189 (1984).

102. See, e.g., 16 U.S.C. $\$ 460 f-1$ to -3 (1982) (mandating consultation with local governing bodies); 16 U.S.C. $\S 459 \mathrm{~b}-3(\mathrm{~b})(2)$ (establishing minimum federal zoning standards, but leaving implementation to local governing bodies subject to federal intervention if the ordinances do not conform).

103. Sierra Club v. Department of the Interior, 376 F. Supp. 90,96 (N.D. Cal. 1974) (Redwood $I_{\text {; }}$ Sierra Club v. Department of the Interior, 398 F.Supp. 284 (N.D. Cal. 1975) (Redwood II); Sierra Club v. Department of the Interior, 424 F.Supp. 172 (N.D. Cal. 1976) (Redwood III). Even in the Redwood litigation, in which the court initially imposed an affirmative protection responsibility on the Secretary, Redwood I at 95-96, the court eventually concluded that the Secretary had met his legal obligations when he submitted the matter to Congress, though this had not yet resolved the Park's problems. Redwood III at 175-76.

104. 487 F. Supp. 443 (D.D.C. 1980).

105. Id. at 450 . See also the Redwood litigation, discussed supra note 103.

106. 468 U.S. 228 (1984). 
tion when it admonished that the judiciary does not have "the authority to replace the Park Service as the manager of the Nation's parks or ... the competence to judge how much protection of park lands is wise and how that level of conservation is to be attained."107

Not surprisingly, federal land management agencies traditionally have not pursued confrontational tactics in dealing with each other, ${ }^{108}$ and there is no evidence that the Park Service regards such tactics as a viable option for dealing with its neighbors in the Yellowstone region. Although the Park Service regards issues like oil and gas exploration adjacent to the parks as a serious threat to park resources, it has limited its direct involvement in these matters to commenting on Forest Service proposals through the National Forest Management Act (NFMA) ${ }^{109}$ and NEPA processes. ${ }^{10}$ Absent clear legal constraints, however, the Forest Service and other neighbors are free to proceed despite Park Service protests-as occurred when Shoshone forest officials recently permitted an oil well near Yellowstone's eastern border, ${ }^{111}$ and when Bridger-Teton forest officials dropped a proposed oil and gas no-leasing buffer zone from the final forest plan. ${ }^{112}$ As we -shall see, it is the Endangered Species Act-not the Park Service Organic Act-that has figured prominently in Forest Service decisions limiting development activity in the proximity of the parks, just as it is the ESA that has prompted several of the regional interagency cooperation initiatives. Therefore, while the amended Organic Act legitimizes Park Service involvement in its neighbors' affairs, the statute has

107. Id. at 299.

108. See Sax \& Keiter, supra note 20, at 221; Report of the Subgroup of the Park ProtecTION WORKING Group (June 12, 1985) (report submitted to the Under Secretary of the Dep't of the Interior); Lockhart, supra note 82, at 7-24. See also 52 Fed. Reg. 35,238 (1987) ("The NPS emphasizes that these regulations apply only to those lands and waters under the legislative jurisdiction of the United States that are located within the exterior boundaries of a park area, not to land or waters that might lie adjacent to such boundaries"; emphasis in original).

109. 16 U.S.C. $\$ \S 1600-1614$ (1982).

110. . 42 U.S.C. $\$ \$ 4321-4370$ (1982). See supra note 20 and accompanying text. See also Sax \& Keiter, supra note 20, at 231-33. But see infra text at notes 312,317 (explaining that the Greater Yellowstone Coordinating Committee is addressing issues such as mineral lease stipulations).

111. Park County Resource Council v. United States Dep't of Agric., 613 F. Supp. 1182 (D. Wyo. 1985), aff'd, 817 F.2d 609 (10th Cir. 1987). Similarly, the Targhee National Forest has continued to clearcut insect-damaged timber located immediately adjacent to Yellowstone's western border, despite protests from Park officials. U.S. Forest Serv., Dep'T of Agric., Targhee National Forest Land Management Plan 326 (1985) [hereinafter Targhee Forest Plan].

112. Bridger-Teton officials originally planned to restrict mineral leasing within a one-half mile zone bordering Grand Teton National Park, but they have dropped this proposal from the Final Forest Plan. Compare U.S. Forest Serv., Dep'T of Agric., bridger-Teton National Forest Land and Resource Management Plan-Proposed forest Plan IV-45 (1987) [hereinafter BridgerTeton Draft forest Plan] with Draft Final Bridger-Teton forest Plan EIS, supro note 78, at $4-453$ to $-54,-479$ to -80 . See also notes 173,283 \& 285 (describing the Sohare Creek oil well exploration project near Grand Teton National Park). 
thus far not been treated as a substantive constraint on adjacent activities.

\section{Wilderness}

The Forest Service administers its wilderness areas under the 1964 Wilderness Act, ${ }^{113}$ which generally contemplates the same "hands off" management philosophy that prevails in the parks. The Act authorizes Congress to set aside roadless public lands to "be administered for the use and enjoyment of the American people in such manner as will leave them unimpaired for future use and enjoyment as wilderness."114 Although the Act does not write man out of the wilderness entirely, ${ }^{115}$ it imposes a general legal duty on the responsible agencies to protect and manage wilderness "so as to preserve its natural conditions," 116 much like the Redwood Park amendment requires

113. 16 U.S.C. $\$ \S 1131-1136$ (1982). See generally Rohlf \& Honnold, Managing the Balance of Nature: The Legal Framework of Wilderness Management, 15 Ecolocy L.Q. 249 (1988).

114. 16 U.S.C. $\$ 1131$ (a) (1982). The Act defines wilderness in some detail:

A wilderness, in contrast with those areas where man and his own works dominate the landscape, is hereby recognized as an area where the earth and its community of life are untrammeled by man, where man himself is a visitor who does not remain ... . An area of wilderness is ... a an area of undeveloped Federal land retaining its primeval character and influence, without permanent improvements or human habituation, which is protected and managed so as to preserve its natural conditions . ...

16 U.S.C. \$1131(c). The Forest Service's implementing regulations provide that wilderness management is based upon the principle of "natural ecological succession"-a management standard closely parallelling the Park Service's "natural process" philosophy. See 36 C.F.R. $\$ 293.2$ (1988).

115. The Act provides that preexisting multiple-use activities, such as grazing and mining, may continue after an area is designated wilderness, and it authorizes fire, insect, and disease control programs. 16 U.S.C. $\$ 1133$ (d) (1982). Moreover, individual wilderness enabling statutes sometimes authorize activities or specific projects incompatible with the basic concept of wilderness. See, e.g., Wyoming Wilderness Act of 1984, § 201(c), 98 Stat. 2807, 2809 (1984) (excepting a transbasin water construction project from the organic Wilderness Act strictures).

116. 16 U.S.C. $\$ \$ 1131$ (a), (c), 1133(b) (providing that "each agency administering any (wilderness] area . . . shall be responsible for preserving the wilderness character of the area and shall so administer such area for such other purposes for which it may have been established as also to preserve its wilderness character"). See Sierra Club v. Block, 622 F. Supp. 842 (D. Colo. 1985), discussed in the text at notes 125-29 infra. These provisions provided Bridger-Teton National Forest officials with ample legal authority for their recent decision not to open the Teton Wilderness Area to salvage logging in the aftermath of a freak, high-elevation tornado that downed more than 15,000 acres of timber. See Casper Star Trib., July 30, 1987, at A1, Aug. 20, 1987, at B1, for descriptions of the "blowdown" controversy. One year later, however, the Forest Service faced renewed criticism for its decision denying salvage access when the downed timber burned during a particularly bad fire season, helping create the largest fire on the Bridger-Teton National Forest in recent history. U.S. NAT'L PARx SERV., U.S. Forest Serv. \& Greater Yellowstone Coordinating Comm., Huck-Mink Fire Review Draft 11 (1988); Casper Star Trib., Sept. 29, 1988, at B1. See also text at notes 89-94, supra, for a description of the fire policy controversy. Although the timber might have eased a local timber shortage, the Forest Service decision went unchallenged. See text at notes $240-48$, infra, for a description of the timber harvesting controversies involving the Bridger-Teton National Forest. 
park officials to protect national park resources from degradation. ${ }^{117}$ Other laws-such as NEPA and the ESA-impose significant additional constraints on wilderness management decisions and have been invoked by the courts to protect wilderness lands from alteration. ${ }^{18}$

Since its inception the Forest Service has enjoyed broad regulatory authority over its own lands. ${ }^{119}$ The courts generally have deferred to the agency's discretion in wilderness management and other matters. ${ }^{120}$ Moreover, the courts have sustained regulations controlling activities on nonfederal lands within the national forests. ${ }^{121}$ In theory, then, the Forest Service might invoke its regulatory authority to limit development on adjacent property bordering its wilderness lands to protect important wilderness ecosystem components such as wildlife or water quality. ${ }^{122}$ But the Forest Service-like the Park Service-is decidedly reluctant to test the scope of its extraterritorial regulatory authority and thus not likely to utilize this power aggressively.

The critical legal question, therefore, in the Yellowstone region and beyond, is whether the Wilderness Act imposes any responsibility on the Forest Service to regulate or limit multiple-use activities on its nonwilderness forest lands to insure the ecological integrity of adjacent wilderness areas. Answering this question is a complex matter, further complicated because the state wilderness designation process is not yet completed for Idaho or Montana. In these states, the Forest Service is under a statutory obligation to preserve the wilderness character of its roadless lands until the wilderness question is resolved. ${ }^{123}$

117. Compare 16 U.S.C. $\$ \S 1131$ (c), 1133(b) with 16 U.S.C. \$ 1a-1. See supra notes $97-101$ and accompanying text.

118. See, e.g., Sierra Club v. Lyng, 694 F. Supp. 1255 (E.D. Tex. 1988) (enjoining the Forest Service from logging in wilderness areas in violation of the Endangered Species Act); Sierra Club v. Block, 614 F. Supp. 488 (D.D.C. 1985) (enjoining the Forest Service from cutting pine beetle-infested trees in several southern wilderness areas because it had not complied with NEPA). But see Sierra Club v. Block, 614 F. Supp. 134 (E.D. Tex. 1985) (finding no NEPA violation when the Forest Service scheduled timber harvesting in wilderness areas to cut pine beetle-infested trees); Cabinet Mountains Wilderness/Scotchman's Peak Grizzly Bears v. Peterson, 685 F.2d 678 (D.C. Cir. 1982) (rejecting NEPA and ESA challenges to a Forest Service decision permitting a mining project in a wilderness area).

119. 16 U.S.C. $\$ 551$ (1982); United States v. Grimaud, 220 U.S. 506 (1911).

120. See, e.g., McMichael v. United States, 355 F.2d 283 (9th Cir. 1965) (sustaining a Forest Service regulation prohibiting motorized vehicles within a primitive area); Sierra Club v. Lyng, 663 F. Supp. 556 (D.D.C. 1987) (reviewing and sustaining, under an abuse of discretion standard, a Forest Service decision authorizing tree cutting in wilderness areas to control insect infestations).

121. See United States v. Arbo, 691 F.2d 863 (9th Cir. 1982); United States v. Linsey, 595 F.2d 5 (9th Cir. 1979).

122. As a practical matter, most wilderness areas in the Yellowstone region and elsewhere are bordered by either the Forest Service's own lands or other federal lands, not by state or private lands. Forest Service regulation of other federal lands presents political problems quite different from those that arise when a federal agency seeks to regulate state or private property.

123. 16 U.S.C. \& 1604(e)(1); California v. Block, 690 F.2d 753 (9th Cir. 1982). Under its NFMA 
But in Wyoming, where the wilderness designation process has been completed, Forest Service management of nonwilderness lands is not constrained by this statutory preservation responsibility, and multipleuse management is specifically sanctioned. ${ }^{124}$

Although the Wilderness Act imposes no express limitations on the use or management of public lands adjacent to designated wilderness areas, it clearly does require Forest Service officials to protect designated wilderness areas. In Sierra Club v. Block, ${ }^{125}$ a Colorado federal district court held that the Act imposes a general legal duty on the Forest Service to protect wilderness resources. Addressing the question of whether the Forest Service is obligated to claim federal reserved water rights for Colorado wilderness areas, the court concluded that "these [Wilderness Act] mandates evince Congress' intent to impose a duty on the administering agencies to protect and preserve all wilderness resources, including water." 126 Although the decision effectively compels the Forest Service to look beyond wilderness boundaries to headwater sources as part of its management responsibilities, the court concluded that it could not order the agency to take such action, thus leaving compliance a matter for agency discretion. ${ }^{127}$ Just as the courts have been loath to impose explicit, enforceable extraterritorial obligations on the Park Service, ${ }^{128}$ this court was reluctant to do so with the Forest Service under the Wilderness Act. Nevertheless, the court's interpretation of the Act plainly endorses the proposition that wilderness lands do not exist in isolation, but are part of a larger regional ecosystem-one that includes entire watersheds. ${ }^{129}$

regulations, the Forest Service must evaluate the wilderness potential of all qualifying roadless areas contiguous to existing wilderness or other undeveloped areas, considering such characteristics as their proximity to other wilderness lands and plant and animal diversity. 36 C.F.R. $\$ 219.17$ (a)(1), (a)(2)(i)(v) (1988).

124. Wyoming Wilderness Act of 1984, Pub. L. No. 98-550 § 401, 98 Stat. 2807, $2811-13$ (1984).

125. 622 F. Supp. 842 (D. Colo. 1985).

126. Id. at 864 . The decision provides significant legal protection for wilderness water flows, an important ecological component of all natural areas. But see Memorandum to Secretary of the Interior from the Solicitor, M-36914 (Supp. III) (July 26, 1988) (concluding that the Wilderness Act does not provide a legal basis for recognizing federal reserved water rights in designated wilderness areas).

127. Id. at 864-65. The court relied upon the absence of a specific statutory provision obligating the Forest Service to assert its reserved water rights. The court also cited Sierra Club v. Department of the Interior, 424 F. Supp. 172 (N.D. Cal. 1976), the Redwood National Park case, to support its conclusion not to compel Forest Service officials to take any particular action to comply with their legal duty. Id. at 864. See supra text at note 103. But see Abrams, Water in the Western Wilderness: The Duty to Assert Reserved Water Rights, 1986 U. ILL. L. REV. 387 (arguing that the Forest Service has a nondiscretionary duty to assert federal reserved water rights to protect wilderness lands).

128. See supra text at notes 102-07.

129. Sierra Club v. Block, 622 F. Supp. 842, 859 (D. Colo. 1985) ("Congress was aware of the need to protect the watersheds in these mostly high alpine areas and, clearly, it intended to carry over and maintain this important purpose in the Wilderness Act"). 
This same conclusion is reflected in other judicial decisions addressing controversies involving roadless lands, in the Yellowstone region and elsewhere, that qualify for wilderness classification. ${ }^{130}$ Relying primarily upon NEPA, the courts have ruled that, before authorizing development proposals on roadless lands and foreclosing the wilderness designation option, the Forest Service must analyze the site-specific environmental consequences of nonwilderness management and consider shifting proposed development activities from undeveloped to already-developed portions of the forest. ${ }^{131}$ In Conner $v$. Burford, ${ }^{132}$ for example, a Montana federal district court enjoined the Forest Service from issuing oil and gas leases on Gallatin National Forest lands (including lands qualifying for wilderness designation) without first undertaking a full NEPA review of the consequences of leasing. ${ }^{133}$ In sum, the decisions suggest that the courts, sensitive to the ecological implications of development on currently roadless lands, are intent on protecting such lands at least during the pendency of the wilderness debate. ${ }^{134}$

In Wyoming and other states where the wilderness classification debate has been completed, however, the state wilderness bills contain provisions "releasing" undesignated lands for multiple use purposes, ${ }^{135}$ and expressly precluding the use of "buffer zones" adjacent to wilderness areas. ${ }^{136}$ These provisions raise the question whether the

130. See, e.g., Parker v. United States, 448 F.2d 793 (10th Cir. 1971); Getty Oil Co. v. Clark, 614 F. Supp. 904,919 (D. Wyo. 1985); Northwest Indian Protective Ass'n v. Peterson, 565 F. Supp. 586, 603 (N.D. Cal. 1983), aff'd on other grounds, 795 F.2d 688 (9th Cir. 1986), rev'd in part on other grounds, 108 S. Ct. 1319 (1988).

131. See California v. Block, 690 F.2d 753, 764-65 (9th Cir. 1982); Earth First! v. Block, 569 F. Supp. 415 (D. Or. 1983).

132. 605 F. Supp. 107 (D. Mont. 1985), aff'd in part \& rev'd in part, 836 F.2d 1521 (9th Cir.), superseded by 848 F.2d 1441 (1988), cert. denied sub nom. Sun Exploration \& Prod. Co. v. Lujan, 109 S. Ct. 112 (1989). See text at notes 266-68, infra, for a description of the case. See also Getty Oil Co. v. Clark, 614 F. Supp. 904 (D. Wyo. 1985), aff'd, 840 F.2d 776 (10th Cir. 1988) (sustaining an IBLA decision requiring additional environmental analysis before an exploratory drilling permit could issue on Bridger-Teton National Forest lands under consideration for wilderness classification).

133. According to the district court, neither the Forest Service's use of leasing stipulations nor its plan to prepare future site-specific environmental analyses complies with NEPA; thus, the agency had undermined "the objective of protecting the area for possible wilderness designation." $605 \mathrm{~F}$. Supp. at 109.

134. This has led knowledgeable commentators to observe that the judiciary effectively has created a de facto wilderness system. Wilkinson \& Anderson, supra note 4, at 334-35.

135. See, e.g., Wyoming Wilderness Act of 1984, $\S 401$ (b)(3), 98 Stat. 2807, 2812; Utah Wilderness Act of 1984, $\S 201$ (b)(3), 98 Stat. 1657, 1658. These provisions represent key compromises that broke the deadlock between conservationists and industry in recent congressional wilderness debates. See generally Wilkinson \& Anderson, supra note 4, at 345.54 for a discussion of the recent wilderness designation process and the evolution of the "release" concept.

136. See, e.g., Wyoming Wildemess Act of $1984, \$ 504,98$ Stat. 2807, 2813; Utah Wildemess Act of 1984, $\S 303,98$ Stat. 1657, 1661. Similarly, general Forest Service policy also precludes the use of buffer zones adjacent to wilderness areas. Forest Service Manual 2320.3-2 (Amend. 97, Apr. 1986). 
Forest Service is legally obligated to open lands abutting wilderness areas (or national parks or wildlife refuges) to commodity development activities, or whether it may continue managing them as undeveloped roadless areas. In Park County Resource Council v. United States Bureau of Land Management, ${ }^{137}$ the court specifically relied upon the 1984 Wyoming Wilderness Act language precluding "buffer zones" to reject a challenge to a Forest Service decision authorizing exploratory drilling in a pristine region located within one-half mile of an established wilderness area. ${ }^{138}$ But the "release" language does not place the Forest Service under an express mandate to open these lands, ${ }^{139}$ nor does it purport to supersede the general protection language in the Wilderness Act itself. ${ }^{140}$ In fact, the court did not examine whether the drilling decision was consistent with the agency's statutory wilderness protection responsibilities, nor did it attempt to harmonize the state wilderness act language with that of the organic Wilderness Act. Thus, notwithstanding this Park County decision, the Forest Service's management discretion and responsibilities are largely unaffected by the "release" language in the recent state wilderness bills. ${ }^{141}$

How Congress resolves the state wilderness debate in Idaho and Montana will have a profound influence on the ecological integrity of the Yellowstone region. The land classification decisions will determine which lands are open or closed to commodity development activities. ${ }^{142}$ And the language included in the bills could influence the Forest Service's management philosophy on adjacent lands. But there

137. 638 F. Supp. 842 (D. Wyo. 1986).

138. The court concluded that the "no buffer zone" provision indicated that Congress did not intend to preclude commodity development activities on these lands. Id. at 845 . The Park County court also rejected NEPA claims, finding that the Forest Service had undertaken sufficient environmental analysis.

139. The statute specifically leaves the matter to be resolved either through the NFMA forest planning process or on a case-by-case basis as specific development proposals surface. Wyoming Wilderness Act of 1984, $\$$ 102(b)(2), 401(b)(3), 98 Stat. 2807. Cf. City of Tenakee Springs v. Block, 778 F.2d 1402 (9th Cir. 1985) (finding a NEPA violation by the Forest Service when it failed to consider a "no action" alternative when reviewing a development proposal for roadless forest lands subject to a "release" provision). See Comment, The National Forest Management Act of 1976: A Critical Look at Two Trees in the NFMA Forest, 22 LAND \& WATER L. REV. 413 (1987).

140. See supra text at notes 113-16, 125-26.

141. Under the NFMA, initial Forest Service management decisions involving these adjacent lands will be made in the forest planning process. The NFMA contains significant environmental protection constraints limiting intensive development, especially if ecologically sensitive areas, such as riparian zones, are threatened. 16 U.S.C. $\$ 1604(\mathrm{~g})(3)(\mathrm{E})$ (1982). Moreover, under accepted multiple-use principles, sensitive lands can effectively be preserved by allocating them for recreation, watershed, or wildlife purposes. 16 U.S.C. $\$ 531$ (a) (1982). See text at notes 187-91, 212-18, infra, for a discussion of the NFMA.

142. See text at notes 291-301, infra. for a more detailed discussion of the current wilderness classification debate in the Greater Yellowstone region. 
is no authority to conclude that specific "release" or "buffer zone" language supersedes the legal protection obligations imposed in the 1964 Wilderness Act, or that this language diminishes other environmental protection or coordination responsibilities. Indeed, the wilderness legislation, viewed in its entirety, supports the principle of ecosystem-based management and affords agency officials sufficient discretionary authority to develop substantive transboundary resource management policies.

\section{B. Wildlife: The Irrelevance of Conventional Boundaries}

Because wild animals do not respect political or administrative boundaries, species population numbers provide a telling measure of the health of the ecosystem. ${ }^{143}$ In the Yellowstone region, for example, ecological concerns are often translated into the question of whether the grizzly bear or some other species is likely to suffer if its habitat is disturbed by human activity. Invariably, this question is now being addressed under federal rather than state law. ${ }^{144}$ The Endangered Species Act, which effectively "trumps" other governing mandates and establishes the U.S. Fish and Wildlife Service as a key participant in most land use controversies, plays a dominant role in land management decisions throughout the region. ${ }^{145}$ The National Forest Management Act, ${ }^{146}$ which endorses the principle of biological diversity as an important factor in forest planning, ${ }^{147}$ also expands federal responsibility for species preservation. Each law represents a serious federal commitment to ecosystem preservation and has influenced agency behavior in the Yellowstone region.

\section{Endangered Species}

Not constrained by boundary limitations, the Endangered Species Act reflects an unambiguous federal commitment to preserve dwin-

143. See supra notes $29-36$ and accompanying text.

144. Although the states traditionally have been responsible for wildlife management on federal, state, and private lands, federal involvement in wildlife management has expanded dramatically in recent years. See M. Bean, The Evolution of National Wildlife LAw 9-47 (1983); Hughes v. Oklahoma, 441 U.S. 322 (1979) (rejecting the state ownership of wildlife theory). Significantly, the federal land management agencies are governed by different wildlife management philosophies, with hunting generally precluded in the national parks but permitted in the national forests subject to state regulation. Compare 16 U.S.C. $\$ 1$ (1982) (mandating that the Park Service conserve wildlife) with 16 U.S.C. $\$ 528$ (1982) (vesting the states with jurisdiction over game and fish on national forest lands). See also 16 U.S.C. $\$ 1133(d)(7)$ (1982) (similarly deferring to state jurisdiction on wilderness lands).

145. 16 U.S.C. $\$ 1536(\mathrm{a})(2)$ (1982). See infra notes $148-85$ and accompanying text.

146. 16 U.S.C. $\$ \S 1600-1687 \cdot(1982)$.

147. 16 U.S.C. $\$ 1604(\mathrm{~g})(3)(B)$ (1982). See infro text at notes $212-18$ (describing the NFMA); text at notes $187-91$ (describing the NFMA biological diversity provision). See also infra note 204 (noting NEPA's biological diversity provision). 
dling species from extinction, regardless of where those species are found. According to the Supreme Court in Tennessee Valley Authority v. $\mathrm{Hill},{ }^{148}$ the ESA attaches a clear national priority to species recovery and conservation efforts. ${ }^{149}$ The Act also connects species conservation with habitat preservation, thus linking two basic ecosystem components. ${ }^{150}$ Moreover, it imposes an affirmative legal duty on all federal agencies to further the statute's conservation purposes, ${ }^{151}$ and it prohibits anyone from unlawfully "taking" a protected species. ${ }^{152}$ The courts have read these provisions strictly, holding that they give species protection priority over other federal agency responsibilities and, therefore, limit agency discretion. ${ }^{153}$ But the courts also have recognized that federal agencies retain considerable discretion in determining how to implement their statutory conservation responsibilities. $^{154}$

148. 437 U.S. 153 (1978).

149. The $T V A$ case dramatically illustrates this. Faced with a claim that the presence of the last surviving remnants of the "endangered" snail darter population should not preclude the Tennessee Valley Authority from completing its nearly finished \$100-million Tellico Dam, the Supreme Court concluded that the Act unambiguously gave priority to the snail darter and it enjoined further construction. Id. at 172-73. It took an act of Congress to complete the dam. Energy and Water Development Appropriation Act, 1980, Pub. L. No. 96-69, 93 Stat. 437, 449 (1979). See generally Note, Endangered Species Act Amendments of 1978: A Congressional Response to Tennessee Valley Authority v. Hill, 5 Colum. J. EnvTl. L. 283, 290-315 (1979); Comment, Congressional Reaction to TVA v. Hill: The 1978 Amendments to the Endangered Species Act, 13 U. RICH. L. REv. 557, 559.77 (1979).

150. 16 U.S.C. $\S 1531$ (b) (1982) (the statute's explicit purpose is "to provide a means whereby the ecosystems upon which endangered species and threatened species depend may be conserved"); 16 U.S.C. $\$ 1533(c)(1)(1982)$ (providing for the Secretary of the Interior to designate critical habitat for designated endangered or threatened species). See also H.R. REP. No. 412, 93d Cong., 1st Sess. (1973) (report accompanying H.R. 37), reprinted in A LegisLative History OF THE E.S.A. OF 1973, As Amended, 97th Cong., 2d Sess. 143-44 (Comm. Print No. 6, 1982).

151. 16 U.S.C. $\$ 1536(a)(1)$ (1982). See Carson-Truckee Conservancy Dist. v. Clark, 741 F. 2d 257, 261 (9th Cir. 1984). See generally France \& Tuholske, Stay the Hand: New Directions for the Endangered Species Act, 7 PUB. LAND L. REv. 1, 4-14 (1986).

152. 16 U.S.C. $\$ 1538(\mathrm{a})(1)(\mathrm{B})(1982) ;$ id. $\$ 1532(19)$ (defining the term "take"). See France \& Tuholske, supra note 151, at 14-18. The "taking" provision makes the ESA applicable on nonfederal lands, limiting private activity that constitutes a "taking" of any listed species. Because "taking" is broadly defined to include habitat modification as an unlawful activity, the Act potentially imposes some restraint on private land development in areas, such as the Yellowstone region, where protected species are found. But see Friends of Endangered Species, Inc. v. Jantzen, 760 F.2d 976 (9th Cir. 1985).

153. See, e.g., Sierra Club v. Clark, 755 F.2d 608, 612-13 (8th Cir. 1985) (holding that "the extent of the Secretary's discretion . . . is limited by the requirement that [his] regulations . . . must provide for the conservation of threatened species"; emphasis in original); Palila v. Hawaii Dep't of Land \& Natural Resources, 639 F.2d 495 (9th Cir. 1981) (holding that the Act's "taking" prohibition precludes agencies from modifying critical habitat when a protected species may be adversely affected). See also CarsonTruckee Water Conservancy Dist. v. Clark, 74 I F.2d 257 (9th Cir. 1984). See generally GoldmanCarter, Federal Conservation of Threatened Species: By Administrative Discretion or By Legislative Standard?, 11 B.C. EnvTL. AfF. L. Rev. 63 (1983).

154. See, e.g., Sierra Club v. Clark, 755 F.2d 608, 619 (8th Cir. 1985); Friends of Endangered Species, Inc. v. Jantzen, 760 F.2d 976, $981-82$ (9th Cir. 1985) (both cases hold that challenges to agency Endangered Species Act determinations are reviewable under the Administrative Procedure Act's "ar- 
Undoubtedly, the Act's most coercive aspect is the effective veto that it grants the U.S. Fish and Wildlife Service over federal agency proposals. $^{135}$ At least theoretically, therefore, the FWS holds the balance of power in public land development controversies when protected species are present. ${ }^{156}$ Its judgments are rarely disturbed by the courts, so long as they are based on the "best available" scientific and commercial evidence. ${ }^{157}$ However, the courts have insisted upon rigorous procedural compliance with the Act's "jeopardy" review process. ${ }^{158}$

The ESA plainly has influenced agency behavior throughout the Yellowstone region, and it also has constrained development on those federal lands where "listed species" are present. ${ }^{159}$ The FWS, Park Service, Forest Service, and other agencies have constituted several interagency committees to address endangered species issues and to develop recovery plans to protect species such as the grizzly bear and bald eagle from habitat loss in Yellowstone and other designated ecosystems. ${ }^{160}$ The interagency grizzly bear recovery committee has

bitrary or capricious" standard, 5 U.S.C. $\$ 706(2)(A)(1982)$ ). See also Cabinet Mountains Wilderness/ Scotchman's Peak Grizzly Bears v. Peterson, 685 F.2d 678 (D.C. Cir. 1982) (rejecting the argument that agency ESA determinations are subject to de now judicial review).

155. The Act grants the Fish and Wildlife Service the authority to review federal agency proposals to insure that they do not "jeopardize" any listed species, i.e., risk further loss of population or habitat. If a proposal might adversely impact a protected species, the FWS will issue a "jeopardy" opinion, which effectively blocks the project until it is redesigned to minimize its impact on protected species. If a proposal will not adversely impact a listed species, the FWS issues a "no jeopardy" opinion, and the proposal can go forward. 16 U.S.C. $\$ 1536(\mathrm{a})(2)$. See Thomas v. Peterson, 753 F.2d 754 (9th Cir. 1985), for a description of the Act's procedural requirements.

156. But see S. Yaffee, Prohibitive Policy: Implementing the Federal Endangered SPECIES ACT $87-89$ (1982) (suggesting that the Fish and Wildlife Service is subject to political pressures, just like other federal agencies); Sax \& Keiter, supra note 20, at 242-43.

157. 16 U.S.C. $\$ 1536(a)(2)$. See Conservation Law Found. v. Watt, 560 F. Supp. 561 (D. Mass.), aff'd, 716 F.2d 946 (1st Cir. 1983); Roosevelt Campobello Int'l Park Comm'n v. United States Envtl. Protection Agency, 684 F.2d 1041 (1st Cir. 1982). However, it is clear that the FWS is not required to base its judgment on irrefutable or "ironclad" data; the courts have recognized that this degree of scientific certainty is often not possible. North Slope Borough v. Andrus, 642 F.2d 589, 609-10 (D.C. Cir. 1980).

158. Conner v. Burford, 848 F.2d 1441 (9th Cir. 1988) (requiring the FWS to prepare a comprehensive biological opinion examining all aspects of the proposal, not a segmented opinion addressing only one phase of the proposed project), cert. denied sub nom. Sun Exploration \& Prod. Co. v. Lujan, 109 S. Ct. 1121 (1989); Thomas v. Peterson, 753 F.2d 754 (9th Cir. 1985) (enjoining a Forest Service road construction project because the agency failed to prepare a statutorily required biological assessment). See also supra note 155 (describing "no jeopardy" opinions).

159. Under the ESA, the Secretary of the Interior is required to compile and publish a "list" of "endangered" and "threatened" species, as determined "solely on the basis of the best scientific and commercial data available." 16 U.S.C. $\$ 1533(b)$, (c) (1982). See 16 U.S.C. $\$ 1532(20)$ (defining "endangered" and "threatened" species). Once a species is "listed," the Act's "jeopardy" review provisions are triggered. See supre note 155.

160. CRS Ecosystem RePORT, supra note 14, at 60; ShOShONe NAT'L Forest, U.S. Forest Serv., INTERagency Grizzly Bear Guidelines 97 (1986) [hereinafter INTERagenCy Grizzly 
adopted a comprehensive land management system for the bear, zoning the federal acreage according to its habitat value ${ }^{161}$ and imposing limits on human activities within areas designated as critically important habitat. ${ }^{162}$ The Custer and Shoshone National Forests have accordingly withdrawn their prime grizzly bear lands from further oil and gas leasing. ${ }^{163}$ Furthermore, the interagency grizzly bear recovery committee has developed a computerized cumulative effects model (CEM) to assess quantitatively the impact that particular projects are likely to have on the bear. ${ }^{164}$ Using the model for the first time, the Gallatin National Forest recently concluded that a controversial ski

BEAR Guidelines] (Memorandum of Understanding to Establish Interagency Committee). Significantly, the grizzly bear recovery plan relies upon the ecosystem designation, i.e., the Greater Yellowstone Grizzly Bear Ecosystem, to define the relevant recovery area. GrizzLy Bear Recovery PlaN, supra note 16 , at 36 .

161. Under the ESA, the Secretary of the Interior is required to designate critical habitat for endangered species "to the maximum extent prudent and determinable." 16 U.S.C. $\$ 1533(\mathrm{a})(3)$ (1982); Enos v. Marsh, 769 F.2d 1363 (9th Cir. 1985). In the Yellowstone region, however, the Secretary has not designated critical grizzly habitat, but instead-responding to intensive political pressurehas created a management zoning system to promote grizzly bear recovery. See T. MCNAMEE, supra note 16, at 169-70. The Interagency Grizzly Bear Recovery Committee, therefore, has established guidelines dividing the region into grizzly bear management zones, with limits imposed on human activity according to the importance of the area to bear recovery goals. For example, in Grizzly Bear Management Situation One areas, which cover more than 5.5 million acres in the Yellowstone region, the bear receives top priority, and incompatible activities are precluded. See GrizzLY BEAR RECOVERY PLAN, supra note 16, at 31-103, for a complete description of this management scheme.

162. FiShiNg Bridge FEIS, supro note 82, at 133; AGGREgATION REPORT, supra note 14, at 3135.

163. Shoshone Forest Plan, supra note 48, at II-70, table II-24 (withdrawing 66,650 acres of Grizzly Bear Situation One lands from oil and gas leasing, out of 2,433,125 total acres); U.S. FOREST Serv., Dep't of Agric., Custer National Forest Final Environmental IMPact Statement 52, 59 (Oct. 1986) [hereinafter CUSTER FOREST PLAN FEIS] (withdrawing 5507 acres of Grizzly Bear Situation One lands from leasing, but leaving more than 100,000 acres of Situation Two lands available for leasing). This decision has not been received favorably by the oil industry, which argues that such a withdrawal is appropriate only if leasing is found to "jeopardize" protected species. 2 U.S. FOREST Serv., Dep't of Agric., Final Environmental. Impact Statement, Shoshone National ForEST VI-107 (1986) [hereinafter Shoshone Forest PLAN FEIS] (comment no. 43 from Conoco); id. at VI-151 (comment no. 48 from Texaco). Though the industry fears the precedential impacts of these decisions, other regional forests have not withdrawn Management Situation One lands from oil and gas leasing, and the FWS has issued "no jeopardy" opinions sanctioning their forest plans. See, e.g., U.S. Forest Serv., Dep't of AGric., Gallatin National Forest Plan at G-35 (1987) [hereinafter Gallatin FOREST PLAN] (imposing leasing stipulations on critical grizzly bear habitat); id. at $\mathbf{H}-5$ (Fish \& Wildlife Service "no jeopardy" opinion). Compare Bridger-Teton Draft Forest Plan, supra note 112, at III-2 (recommending withdrawal from leasing of more than 678,000 acres of Situation One lands) with Draft Final Bridger-Teton Forest Plan FEIS, supro note 78, at 4-322 (dropping this withdrawal recommendation and sanctioning leasing on Situation One lands with protective stipulations).

164. The CEM model utilizes habitat, displacement, and mortality data to predict through computer analysis the cumulative impact that particular land use decisions are likely to have on the grizzly bear. See Gallatin Nat'l Forest, U.S. Forest Serv., Cumulative Effects Analysis Process for the Yellowstone Ecosystem, Ski Yellowstone Biological Assessment, App. I (June 1987) [hereinafter SKI YeLLowSTONE BIOLOGICAL ASSESSMENT]. 
resort proposal involving lands outside West Yellowstone, Montana, may negatively impact the area bear population, and it consequently reversed an earlier decision granting the requested permit. ${ }^{165}$ These cooperative efforts are not only breaking down traditional agency "turf" prerogatives, they have legitimized regional management as a necessary strategy for implementing the Act.

Perhaps because the federal land management agencies have been responsive to the ESA's mandates, the courts infrequently have invoked the statute to restrain development in the Yellowstone region. In National Wildlife Federation v. National Park Service, ${ }^{166}$ for example, a Wyoming federal district court rejected the claim that opening Yellowstone National Park's Fishing Bridge campground violated the Act, finding sufficient evidence to sustain the Park Service's interim management plan. ${ }^{167}$ Similarly, in Park County Resource Council v. United States Department of Agriculture, ${ }^{168}$ the court refused to enjoin exploratory oil drilling in the Shoshone National Forest on lands used

165. Id. at 87-89. Developers have proposed a year-round resort to be known as Ski Yellowstone, which would be located near Hebgen Lake just outside West Yellowstone, a gateway community to the Park that is heavily dependent upon tourist traffic. If constructed, the resort could provide a boost for West Yellowstone's seasonally depressed economy. The resort site, however, is located in important. grizzly bear habitat. Although the Forest Service approved the resort in 1982, it recently reevaluated the proposal using the CEM, and concluded that the ski complex and the accompanying condominium construction on adjacent private lands "may affect" the grizzly bear and bald eagle populations, in violation of the Endangered Species Act. The Forest Service is now unwilling to grant the permit unless the resort is limited to winter operation, when it would be possible to control the on- and offsite impacts of the development. Id. at 91 . But the Forest Service has not precluded eventual development of the project. U.S. Forest Serv., Record of Decision, LANd \& Resource Management Plan for the Gallatin National Forest 8 (1987) [hereinafter Gallatin Forest Plan Record of Decision]. Cf. Robertson v. Methow Valley Citizens Council, 109 S. Ct. 1835 (1989) (holding that the Forest Service has no substantive NEPA mitigation obligation, and that Forest Service regulations do not obligate the agency to implement offsite mitigation measures before issuing a special use permit).

166. 669 F. Supp. 384 (D. Wyo. 1987). The court rejected several ESA arguments, including the claim that continued operation of the campground violated the Park Service's conservation responsibilities under $\$ 1536(a)(1)$, that it constituted an impermissible "taking" under $\$ 1532(19)$, and that it was in violation of an established recovery plan under $\$ 1533(f)$. See. also supra note 87.

167. The court clearly was swayed by the facts that the Park Service was acting consistent with the interagency grizzly bear recovery plan and that it planned to use the CEM model to assess the impact of the campground on the bear. 669 F. Supp. at 387-88. Significantly, however, the court rejected the plaintiff's procedural argument based on the Park Service's failure to prepare a written "incidental takings" plan as mandated by 16 U.S.C. $\$ 1536(b)(4)$. This ruling deviates from well-accepted ESA precedent holding agencies to rigorous compliance with statutory procedural requirements. 669 F. Supp. at 389-90. See Conner v. Burford, 848 F.2d 1441, 1455 (9th Cir. 1988), cert. denied sub nom. Sun Exploration \& Prod. Co. v. Lujan, 109 S. Ct. 112 (1989); Thomas v. Peterson, 753 F.2d 754, 764 (9th Cir. 1985). Since then, the Park Service has recommended keeping the recreational vehicle campground open, and the FWS, applying the CEM analysis, has concluded that this decision will not affect the bear adversely, even though the Park Service eventually may construct another campground nearby. Fishing Bridge FEIS, supra note 82, at 367-72 (Fish \& Wildlife Service Biological Opinion, Oct. 13, 1987).

168. 613 F. Supp. 1182 (D. Wyo. 1985). 
by grizzly bears, finding no basis for reconsidering the FWS's "no jeopardy" opinion. ${ }^{169}$ In Conner v. Burford, ${ }^{170}$ however, the Ninth Circuit read rigorous procedural requirements into the statute, holding that the FWS must prepare a comprehensive-not segmentedbiological assessment of the consequences of oil and gas leasing on "listed" species based on the best scientific data available. ${ }^{171}$ Viewed together, the decisions reflect a judicial reluctance to involve the courts in matters of scientific complexity and uncertainty, ${ }^{172}$ tempered by a commitment to insuring that the agencies meet the statute's procedural requirements. ${ }^{173}$

Probably the most controversial endangered species issue confronting the federal agencies in the Yellowstone region is reintroduction of the extirpated gray wolf, a major native predator exterminated during the early 1900s. As a symbolic matter, the wolf reintroduction proposal represents a major shift in public land management philosophy in the West, but one that is consistent with the ongoing transition from a utilitarian-based to an amenity-focused management philosophy. Under the ESA, the Secretary of the Interior is authorized to introduce experimental species populations, ${ }^{174}$ and the FWS has prepared a Wolf Recovery Plan identifying Yellowstone National Park as an appropriate setting for wolf reintroduction. ${ }^{175}$ But the Secretary is not expressly obligated to reintroduce experimental populations; the

169. See supra note 155 (describing "no jeopardy" opinions). Following precedent, the Park County court reviewed the ESA claim under an "arbitrary and capricious" standard. 613 F. Supp. at 1186. The court was impressed by the mitigation measures imposed by the FWS, including the requirement of site access by helicopter. Id. at 1184, 1188 .

170. 848 F.2d 1441 (9th Cir. 1988), cert. denied sub nom. Sun Exploration \& Prod. Co. v. Lujan, 109 S. Ct. 112 (1989).

171. Id. at 1453. Although the Forest Service argued that it was obligated under the ESA to address only the leasing stage in the oil and gas development process, the court ruled that it was also responsible for anticipating the impact of drilling and development on endangered species.

172. But see Northern Spotted Owl v. Hodel, No. C8-573 (W.D. Wash. Nov. 17, 1988) (WL 149253) (finding that the FWS arbitrarily declined to "list" the spotted owl under the ESA).

173. But see Sierra Club, 104 IBLA 76, 88 (U.S. Dep't of the Interior, IBLA 88-442) (Sept. 29, 1988) (rejecting environmental groups' ESA argument that use of an elk habitat model, rather than the CEM model, to evaluate the effect on the grizzly bear of exploratory drilling at Sohare Creek in the Mt. Leidy Highlands of the Bridger-Teton National Forest violated the Act's "best available scientific data" provision). See also infra note 285 .

174. 16 U.S.C. $\S 1539$ (j); 50 C.F.R. $\S \S 17.80-84$ (1988). See 1982 U.S. CoDE CONG. \& ADmIN. NEWS, 2833-35, 2845-46, 2857, 2870-76. Moreover, the FWS has a statutory duty to "develop and implement" recovery plans for endangered and threatened species, which also might provide a legal basis for wolf reintroduction. 16 U.S.C. $\$ 1533(f)$. Cf. Sierra Club v. Clark, 755 F.2d 608 (8th Cir. 1985) (holding that the ESA's "conservation" requirement precluded the Secretary of the Interior from authorizing a wolf sport hunting season).

175. Wolf Recovery Plan, supra note 38, at 13-14, 22-30. The Plan proposes a comprehensive management zoning scheme involving park and forest lands similar to the one used for the grizzly bear. Wolf recovery would be promoted and take precedence on lands designated as Zone One-those areas where conflict between the wolf and other land uses is low. Zone Two lands would serve as a 
statutory language is discretionary unless it can be shown that reintroduction is the only feasible means to insure species preservation. ${ }^{176}$ The presence of reintroduced wolves protected as a "listed" species could have legal repercussions for the multiple-use agencies, placing them under a mandate to adjust their agendas to accommodate the wolf. ${ }^{177}$

The Park Service, citing its natural management philosophy, believes that wolves would help restore a natural ecological balance in the Yellowstone region. ${ }^{178}$ The livestock industry, however, opposes reintroduction, fearing that wolves would stray outside the Park and prey upon domestic cattle and sheep. ${ }^{179}$ Among the federal agencies, only the Park Service has publicly endorsed reintroduction; the others have not taken a position on the question. ${ }^{180}$ The State of Wyoming strongly opposes reintroduction and the Wyoming congressional delegation has intervened to thwart a NEPA review initiative, apparently strong-arming the Park Service into retreating from its position. ${ }^{181}$ Thus, despite the ESA's powerful species recovery objectives, local economic interests have had sufficient political clout to preclude an open dialogue on this question. ${ }^{182}$ In other words, while wolf reintroduction may make eminent ecological sense in Yellowstone $\mathrm{Na}$ tional Park, nonecological concerns focused on human interests outside the park cannot be ignored.

buffer to Zone Three lands where conflict is likely to be high and where human activities would be accorded primacy. Id. at v, 31-36.

176. "The Secretary may authorize the release .. . of any population ... of an endangered species or a threatened species outside the current range of such species if the Secretary determines that such release will further the conservation of such species." 16 U.S.C. $\$ 1539(j)(2)(A)$.

177. Under the Act, reintroduced wolves would be treated as "threatened" species, even if they originated from a pack designated as "endangered." 16 U.S.C. $\$ 1539(j)(2)(C)$. This would permit the agencies to formulate special rules to control these wolves, including provisions to kill problem animals (i.e., those preying on livestock) and to transport them back into the park if they strayed onto private lands. See Wolf Recovery Plan, supra note 38, at 36-38.

178. Yellowstone Management Plan, supra note 82, at 98-101.

179. The livestock industry's major concern is that ranchers would be powerless to respond to wolf depredations because the wolf is a protected species under the Act. Sportsmen's organizations composed of hunters also are concerned about wolf reintroduction; they worry that a growing wolf population could deplete big game numbers and force hunting closures. Zumbo, Should We Cry Wolf?, Outdoor Life, Dec. 1987, at 50. But see O'Neill, The Law of Wolves, 18 ENVTL. L. 227 (1988) (summarizing Minnesota's experience with the timber wolf as a protected species under the Endangered Species Act).

180. See 36 C.F.R. $\S 219.19$ (a)(3) (1988) (obligating the Forest Service, in the forest planning process, to consult other agencies about opportunities to reintroduce species); DRAFT FINAL BRIDGERTETON FOREST, Plan EIS, supra note 78, at 3-142.

181. Casper Star Trib., Aug. 8, 1987, at B1; Casper Star Trib., Nov. 11, 1987, at B1. See also New York Times, June 3, 1986, §3, at 4, col 6.

182. However, Congress recently has appropriated funds to begin studying the wolf reintroduction issue, the initial step toward preparation of an EIS. Casper Star Trib., Sept. 9, 1988, at B1. 
The dominant legal influence exerted by the Endangered Species Act on land use decisions in the Yellowstone region largely depends upon the continued listing of the wide-ranging grizzly bear as a covered species. Yet Montana and Wyoming are interested in "delisting" the bear, ${ }^{183}$ and recent reports suggest a favorable upswing in population statistics, which eventually might support a delisting effort. ${ }^{184}$ In the long run, therefore, the greatest impact of the Act in the Yellowstone region could be that it has compelled the agencies to disregard traditional "turf" prerogatives and to work together toward the common goal of species recovery, thus legitimating an explicit form of ecosystem-based management. But whether these interagency efforts are yet making a real difference is subject to dispute. As we shall see, a recent federal report casts serious doubt on whether the agencies have implemented meaningful, coordinated efforts on endangered species issues. ${ }^{185}$ This finding raises the question whether the land management agencies can successfully address ecological issues other than endangered species concerns through interagency procedural mechanisms when they are under no legal compulsion similar to that found in the ESA.

\section{Biological Diversity}

Because the Endangered Species Act compels government agencies to focus on species facing imminent extinction, "unlisted" species-especially those little noticed by the public and not easily valued economically - have been historically overlooked by land managers, regardless of their intrinsic ecological importance. ${ }^{186}$ Reflecting Congress's concern that forest management should be based on sound scientific principles, ${ }^{187}$ the National Forest Management Act's biological

183. See Montana Dep't of Fish, Wildlife \& Parks, Final Programmatic eis: The Grizzly Bear IN Northwestern MONTANA, Summary (1986). The states' interest may be premature, however. The Yellowstone Ecosystem Recovery Plan sets a bear population goal of 301 bears, but recent population estimates are 183-207 bears, with projections of a $1.7 \%$ per year decline in the population. Fishing Bridge FEIS, supra note 82, at 134; CRS ECOSYSTEM REPORT, supra note 14, at 48. 49.

184. Laramie Daily Boomerang, July 30, 1988, at 7 (reporting that adult female bears in the Yeilowstone Ecosystem totaled 45 in 1985, whereas there were only 32 adult females in 1983); id., Sept. 30,1988 , at 7 (reporting that an Interagency Grizzly Bear Committee scientific task force reported a 0.07 to 1.5 percent increase in the Yellowstone grizzly bear population for 1987 and a current regional population estimate of 170-180 bears). See also Casper Star Trib., May 7, 1989, at A1 (reporting increased grizzly sightings outside Yellowstone National Park). But see supra note 183.

185. CRS ECOSYSTEM REPORT, supra note 14, at 9 (noting that the agencies failed to maintain uniformly consistent information on grizzly bear fatalities); id. at 16 (concluding that there have been an unacceptably high number of grizzly mortalities). See infra text at notes 308-11.

186. M. BEAN, supra note 144, at 329-30, 410-411.

187. S. ReP. No. 893, 94th Cong., 2d Sess. 4, 10, reprinted in 1976 U.S. CODE CONG. \& AdMIN NEWS 6665, 6671. However, neither the NFMA nor the implementing regulations rely upon scientific 
diversity provision addresses this problem by giving legal protection to this important dimension of the ecosystem. It requires the Forest Service to "provide for diversity of plant and animal communities based on the suitability and capability of the specific land area in order to meet overall multiple-use objectives." ${ }^{188}$ The implementing regulations provide that biological diversity shall be preserved "so that it is at least as great as that which would be expected in a natural forest."189 After designating representative "management indicator species," the Forest Service is required to set habitat preservation goals and to monitor population fluctuations. ${ }^{190}$ Thus, the biological diversity provision reflects a clear congressional commitment to an ecosystem-based forest managment policy, and it constitutes a substantive constraint on traditional consumptive-use practices. ${ }^{191}$

Since the forest planning process is just reaching completion, there are few judicial constructions of the NFMA. ${ }^{192}$ It is too early,

formulas or incorporate any particular conservation biology theory. See Final Report of the Committee of Scientists, 44 Fed. Reg. 26,599, 26,609 (1979). See also supro notes $31-36$ and accompanying text for a discussion of the role biological diversity plays in the ecosystem.

188. 16 U.S.C. $\$ 1604(\mathrm{~g})(3)(B)$. The provision further states: "[A]nd within the multiple-use objectives of a land management plan adopted pursuant to this section, provide, where appropriate, to the degree practicable, for steps to be taken to preserve the diversity of tree species similar to that existing in the region controlled by the plan." Id. See Wilkinson \& Anderson, supra note 4, at 290-96, for a description of the congressional committee debates over the diversity provision. The implementing regulation apparently injects some flexibility into the diversity requirement: It provides for diversity reductions, but "only where needed to meet overall multiple use objectives." 36 C.F.R. $\$ 219.27(\mathrm{~g})$ (1988) (emphasis added). Despite this apparent qualifying language, Congress was committed to restoring a natural ecological setting in the national forests, something that was rapidly disappearing from the southern forests as the hardwoods were being harvested and replaced by faster growing pines. See generally Wilkinson \& Anderson, supra note 4, at 170-73. But see Appeal Decision, Flathead Notional Forest Land \& Resource Management Plan Appeals, U.S. Forest Service Nos. 1467, 1513, 13-14 (Aug. 31, 1988) [hereinafter Flathead Forest Plan Appeal Decision] (holding that the NFMA diversity provision requirements are "procedural in nature," and that the Forest Service is not obligated to maintain "any specified level of abundance or distribution of particular plant or animal communities").

189. 36 C.F.R. $\$ 219.27(\mathrm{~g})(1988)$. This regulation defines biological diversity requirements as a forest management prescription, a definition intended to set minimum management requirements for forest planners. The regulations obligate the Forest Service "to maintain viable populations of existing native and desired species," primarily by preserving adequate habitat, well distributed throughout the forest, to facilitate species interactions. Id. $\$ 219.19$. These goals are implemented by requiring the Forest Service to designate "management indicator species," defined as species selected because their population numbers are likely to reflect the effects of forest activities on the ecosystem. 36 C.F.R. $\$ 219.12(a)(1)(1988) ; 36$ C.F.R. $\$ 219.19(a)(1)-(a)(7)$ (indicator species selection guidelines). See generally O'Riordan \& Horngren, The Minimum Management Requirements of Forest Planning, 17 ENVTL. L. 643 (1987).

190. 36 C.F.R. § 219.19(a)(7) (1988) (habitat goals); 36 C.F.R. \$ 219.19(a)(6) (monitoring).

191. See Wilkinson \& Anderson, supra note 4, at 296 ("It is evident that section 6(B)(3)(B) requires Forest Service planners to treat the wildlife resource as a controlling, co-equal factor in forest management and, in particular, as a substantive limitation on timber production.").

192. Only one court appears to have reviewed an NFMA claim alleging a violation of substantive limitations on the Forest Service's discretionary authority. See Big Hole Ranchers Ass'n v. United States Forest Serv., 686 F. Supp. 256, 264 (D. Mont. 1988) (utilizing an arbitrariness standard to review 
therefore, to know how rigorously the courts will read the statute or how carefully they will review the Forest Service's planning decisions. But considering the complexity of the forest planning process, judicial review of NFMA appeals involving substantive standards, such as the biological diversity requirement, probably will be based upon the same "abuse of discretion" standard that the courts have applied in previous challenges to forest management decisions. ${ }^{193}$ Given the judiciary's well-documented reluctance to review scientific matters, disputes concerning scientific methodology or data interpretation most likely will be resolved in the agency's favor, barring a deviation from accepted practice or clear procedural deficiencies. ${ }^{194}$

Several diversity issues are already the focus of administrative forest plan appeals in the Yellowstone region. One of the most controversial issues is whether the Forest Service has selected appropriate species as indicator species. ${ }^{195}$ Using certain indicator species to measure the health of the forest could limit traditional commodity development activities. ${ }^{196}$ For example, species that depend upon old growth forests, such as cavity-nesting raptors and pine marten, or that require undisturbed riparian habitat, such as mink and otter, are likely to be displaced by extensive timber harvesting and roadbuilding projects. ${ }^{197}$ Other potential issues include whether the forest plan pre-

a claim alleging violation of a NFMA timber harvest restocking regulation). This can be explained by the fact that the Forest Service has issued final administrative decisions in only a few of the 91 forest plan appeals that have been filed, although 19 conservationist appeals have been settled and several forest plans either have been remanded or withdrawn for further planning. Four lawsuits challenging forest plans have been filed. Status of the National Forest Planning Process, Forest IssuEs BULL., Feb./Mar. 1989, at 8 (published by The Wilderness Society).

193. Perkins v. Bergland, 608 F.2d 803, 806-07 (9th Cir. 1973); Big Hole Ranchers Ass'n v. United States Forest Serv., 686 F. Supp. 256, 263-64 (D. Mont. 1988); National Wildlife Fed'n v. United States Forest Serv., 592 F. Supp. $931,938-39$ (D. Ore. 1984); Dorothy Thomas Found., Inc. v. Hardin, 317 F. Supp. 1072, 1076 (W.D.N.C. 1970). See also W. Burgess, Standards for Judicial Review of Forest Plans: Will the Courts Not See the Forest for the Trees? (June 8-10, 1987) (paper presented at: The Public Lands During the Remainder of the 20th Century: Planning, Law, and Policy in the Federal Land Agencies, Eighth Annual Summer Program, University of Colorado). Cf. Sierra Club v. Clark, 756 F.2d 686, 690 (9th Cir. 1985) (reviewing a challenge to the BLM's FLPMA planning decisions under an arbitrariness standard).

194. See Sierra Club v. Froehlke, 816 F.2d 205 (5th Cir. 1987); Northern Spotted Owl v. Hodel, No. C88-573 (W.D. Wash. Nov. 17, 1988) (WL 149253).

195. See, e.g., Gallatin National Forest Plan Appeal, U.S. Forest Service Appeal No. 2134, Natural Resources Defense Council, et al., Appellants, Statement of Reasons 216-35 (Feb. 1, 1988) [hereinafter Gallatin Forest Plan Appeal]; Custer Forest Plan Appeal, U.S. Forest Service, Greater Yellowstone Coalition, et al., Appellants, Statement of Reasons $89-98$ (Sept. 15, 1987) [hereinafter Custer Forest Plan Appleal].

196. See infra notes 199-202 and accompanying text for a discussion of the impact of the spotted owl on timber harvesting in the Pacific Northwest.

197. L. HARRIS, supra note 7, at 141-44; CRS ECOSYSTEM REPORT, supra note 14, at 77-79. 
serves sufficient habitat to insure viable populations, and whether the plan's viable population projections insure against species depletion. ${ }^{198}$

The impact that resolution of these issues is likely to have on forest management practices already can be seen in the Pacific Northwest where a major controversy is raging over use of the spotted owl as an indicator species. Citing the loss of spotted owl habitat and dwindling population numbers, environmentalists assert that old growth timber harvesting must be curtailed to protect the owl's remaining habitat. ${ }^{199}$ The timber industry, on the other hand, views using the spotted owl as an indicator species as a potential threat to its timber supply. ${ }^{200}$ Faced with clear statutory diversity obligations, the Forest Service has selected the spotted owl as an indicator species and plans to curtail old growth timber harvesting to protect the bird's habitat. ${ }^{201}$ Moreover, the spotted owl issue has generated intense public interest and involvement in forest management practices throughout the region. ${ }^{202}$ This has, in turn, broadened the general public's understanding of the ecological concept of diversity, and the Forest Service has been unable to ignore this public pressure. The same phenomenon could occur in the Yellowstone region as the diversity concept becomes better known and understood.

The NFMA biological diversity provision is a powerful concept even though it is somewhat qualified by ambiguous statutory refer-

198. See Forest Plan Appeals cited supra note 195. See also Flathead Forest Plan Appeal Decision, supra note 188, at 11-21.

199. Nat'l Audubon Soc'y, Audubon Conservation Rep. No. 7, Report of the AdVISORY PANel ON THE SPOTTEd OWL (1986); WILDERNESS SOCIETY, FORESTS OF THE FUTURE? 73 (1987) [hereinafter Forests of the Future?]. See 1 U.S. Forest SERV., Dep'T of AGric., Final

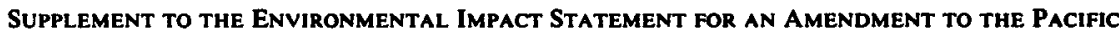
Northwest Regional Guide, Spotted OWl Guidelines (1988) thereinafter SpotTed Owl SEIS]; Lane County Audubon Soc'y, 85 IBLA 185 (1985) (discussing the importance of old-growth timber habitat to the spotted owl's survival). See also Endangered and Threatened Wildlife and Plants; Finding on Northern Spotted Owl Petition, 52 Fed. Reg. 48,552 (1987) (Fish and Wildlife Service refusal to list the spotted owl as endangered at this time); Northern Spotted Owl v. Hodel, No. C88-573 (W.D. Wash. Nov. 17, 1988) (WL 149253) (finding that the FWS acted arbitrarily and capriciously when it decided not to "list" the spotted owl under the ESA); N.Y. Times, Nov. 18, 1988, at A16, col. 4; High Country News, May 8, 1989, at 3 (reporting that the FWS is recommending the spotted owl be listed as a "threatened" species).

200. The Forest Service plans to set aside $\mathbf{5 5 0}$ spotted owl habitat areas, each containing 1000 to 2700 acres of old-growth forest that would be off-limits to timber harvesting. SPOTTED OWL SEIS, supra note 199, at S-18, I-15; FORESTS OF THE FUTURE?, supra note 199, at 73. Annually, this would reduce timber harvest levels by 163 million board feet and reportedly eliminate 450 to 900 jobs in the timber industry. SPOTTEd OWL SEIS, supra note 199, at S-40, S-42. See generally Stahl, As the Forest Falls: The Controversy over Minimum Management Requirements, FOREST WATCH, July 1987, at 9; N.Y. Times, Aug. 17, 1988, at Al, col. 1.

201. SPOTTED OWL SEIS, supra note 199 , at I-8 to -15, S-38 to -43 .

202. The Forest Service received more than 40,000 responses to its proposed spotted owl management guidelines. SPOTTED OWL SEIS, supra note 199, at I-13. 
ences to multiple-use principles. ${ }^{203}$ Biological diversity has become a part of the working vocabulary of forest managers, injecting hitherto ignored ecological considerations into the planning process. As refiected in the spotted owl controversy, the diversity requirement can have the same limiting effect on intensive multiple-use practices that endangered species protection now has. While not yet fully understood by the public-or even by land managers-it nonetheless is refocusing the debate over forest management practices to include concern for the ecosystem as a whole, a concern that necessarily transcends existing boundary limitations. ${ }^{204}$

\section{The Multiple-Use Lands: A Struggle For Dominance}

The fundamental question confronting the Forest Service in the Greater Yellowstone region is the appropriate level of development of its roadless nonwilderness lands. Stressing the ecological interconnectedness of the region, environmental groups assert that the Forest Service's consumptive-use plans threaten the integrity of the region, are not coordinated with adjacent land management policies, and violate laws such as the NFMA, ESA, and Clean Water Act. ${ }^{205}$ On the other hand, the timber and mineral industries assert that the multipleuse forest lands should be open to consumptive-use activities, citing Congress's wilderness designation decisions as evidence that it intended to open nonwilderness forest lands to development. ${ }^{206}$ Similar concerns about Forest Service policy are evident within other federal agencies $^{207}$ and among the general public. ${ }^{208}$ An examination of these

203. See supra note 188 and accompanying text.

204. NEPA also contains a biological diversity provision, 42 U.S.C. $\$ 4331$ (b)(4) (1982), but it has received even less attention than has the NFMA requirement. But see SENATE COMM. ON ENVIronment and Public Works, Authorizing Appropriations for the Office of EnvironmenTAL QUality for Fiscal Year 1987, 1988 and 1989, S. Rep. No. 502, 100th Cong., 2d Sess. 6 (1988) (report accompanying S. 1792, concluding that "conservation of biological diversity under NEPA should be inherent in all facets of the NEPA decision-making process"). See generally Carlson, NEPA and the Conservation of Biological Diversity, 19 ENvTL. L. 15 (1988).

205. Clean Water Act, 33 U.S.C. $\$ \S 1251-1387$ (1982 \& Supp. V 1987). See, e.g., Gallatin Forest Plan Appeal, supra note 195, at 73-101, 141-58, 236 (Statement of Reasons); Custer Forest Plan Appeal, supra note 195, at 49.73, 126 (Statement of Reasons).

206. See, e.g., Shoshone Forest Plan FEIS supra note 163, at VI-309 (letter from Wendy H. Frueauf, Petroleum Association of Wyoming, objecting to restrictions on the oil and gas industry); id. at VI-484 (letter from Amoco Production Co. objecting to mineral leasing restrictions).

207. The Park Service and the FWS have reminded the Forest Service that extensive clear cutting and unrestrained mineral exploration could harm adjacent lands and resources. See, e.g., GALLATIN Forest Plan FEIS, supra note 20, at VI-32 to -40 (Yellowstone National Park Comments); id. at VI83, -84 (U.S. Fish \& Wildlife Service Biological Opinion); letter from Robert Stewart, Dep't of the Interior Office of Environmental Project Review, to Brian Stout, Bridger-Teton National Forest Supervisor (Feb. 25, 1987) (available from author).

208. The forest planning process has fostered previously unexperienced levels of public involvement in forest management issues. See, e.g., Shoshone Forest Plan FEIS, supra note 163, at VI-5 
conflicts reveals how current law is influencing the Forest Service's multiple-use agenda, the limits of judicial intervention, and Congress's role as ultimate arbiter of the fate of the public domain.

\section{An Overview}

The Forest Service manages its lands under the multiple-use principle set forth in the 1960 Multiple Use-Sustained Yield Act, ${ }^{209}$ which provides that the national forests "shall be administered for outdoor recreation, range, timber, watershed, and wildlife and fish purposes."210 Not surprisingly, the courts consistently have construed this multiple-use mandate as according the Forest Service broad discretionary management authority. ${ }^{211}$ In 1976, however, responding to the public outcry over Forest Service timber harvesting practices, Congress adopted the National Forest Management Act, ${ }^{212}$ establishing a comprehensive, interdisciplinary land management planning process for each forest and opening that process to public involvement. ${ }^{213}$ Although the NFMA endorses the multiple-use principle, it also imposes significant environmental constraints on forest management practices $^{214}$ and obligates forest planners to coordinate with adjacent

(185 written comments received); Gallatin Forest Plan FEIS, supro note 20, at I-4 (over 2000 letters received); U.S. Forest Serv., Dep't of Agric., Bridger-Teton National Forest PlanNING UPDATE (1987) [hereinafter B-T PLANNING UPDATE] (9052 comments received during the fourmonth comment period).

209. 16 U.S.C. $\$ \$ 528-531$ (1982). Several important forest management principles can be extracted from the Act's definition of "multiple use": Management is to "best meet the needs of the American people"; land is to be used for "some or all" of the resources, but "some land will be used for less than all of the resources"; and management of resources is to be "coordinated" without impairing the productivity of the land but not necessarily to "give the greatest dollar return." Id. \$ $531(\mathrm{a})$.

210. 16 U.S.C. \$ 528. The 1960 Multiple Use-Sustained Yield Act substantially broadened the Forest Service's original organic mandate, which provided that the forests were established for timber production and watershed protection. 16 U.S.C. $\$ 475$ (1982). See United States v. New Mexico, 438 U.S. 696 (1978).

211. See, e.g., McMichael v. United States, 355 F.2d 283, 286 (9th Cir. 1965); National Wildlife Fed'n v. United States Forest Serv., 592 F. Supp. 931,938 (D. Or. 1984); Dorothy Thomas Found., Inc. v. Hardin, 317 F. Supp. 1072, (W.D.N.C. 1970). See also Coggins, Of Succotash Syndromes and Vacuous Platitudes: The Meaning of "Multiple Use, Sustained Yield" for Public Land Management, 53 U. CoLO. L. REV. 229 (1981).

212. 16 U.S.C. $\$ 1600-1614$ (1982). See generally Wilkinson \& Anderson, supra note 4.

213. 16 U.S.C. \$ 1604. See 16 U.S.C. \$ 1604 (b) (interdisciplinary planning provision); 16 U.S.C. $\$ 1604(\mathrm{~d})$ (public involvement provision); 16 U.S.C. $\$ 1604(\mathrm{~g})(1)$ (NEPA procedures incorporated into forest planning process). See also Methow Valley Citizens Council v. Regional Forester, 16 Evntl. L. Rep. (Envtl. L. Inst.) 20,641, 20,644 (D. Or. 1986) (WL 8595) (observing that Congress intended NFMA to "bind the agency to a deliberate, public decision process"), rev'd on other grounds, $833 \mathrm{~F} .2 \mathrm{~d}$ 810 (9th Cir. 1987), nev'd sub nom. Robertson v. Methow Valley Citizens Council, 109 S. Ct. 1835 (1989).

214. 16 U.S.C. $\$ 1604(g)(3)(E)$, (F) (limiting timber harvesting to protect soil stability, water quality, and riparian lands, and restraining clearcutting as a harvest method). See also text at notes 187-91, supra, discussing the biological diversity provision as a limitation. Moreover, the NFMA re- 
federal, state, and local land managers. ${ }^{215}$ The NFMA's mandate to appoint an independent committee of scientists to provide "scientific and technical advice" on the proposed implementing regulations ${ }^{216}$ reflects a serious congressional commitment to integrating ecologically based management principles into the Forest Service's multiple-use practices.

Because the NFMA forest plans will be the "law" of the forest once they are completed, ${ }^{217}$ the forest planning process is regarded by environmental groups and industry as a critical juncture in the formulation of forest policy. But this perception may be illusory. Recent Forest Service NFMA administrative appeal decisions emphasize the discretionary, flexible, and essentially nonbinding nature of forest planning determinations. ${ }^{218}$

Forest management is also subject to many other laws, including statutes governing specific natural resources and myriad environmental protection laws. ${ }^{219}$ The National Environmental Policy Act $^{220}$ oc-

quires forest planners to take account of aesthetic values when planning timber management programs. 16 U.S.C. $\$ 1604(\mathrm{~g})(3)(\mathrm{F})(\mathrm{iii})(\mathrm{iv})$.

215. 16 U.S.C. $\$ 1604($ a). See text at notes $322-31$ infra for further discussion of this coordination provision.

216. 16 U.S.C. $\$ 1604(\mathrm{~h})$. The Committee of Scientists was composed of individuals recommended by the National Academy of Sciences, and it reviewed and critiqued several draft versions of the Forest Service's proposed NFMA regulations. See 44 Fed. Reg. 26.599 (1979); Wilkinson \& Anderson, supra note 4, at 43-44.

217. See 16 U.S.C. $\$ 1604$ (i); 36 C.F.R. $\$ 219.1$ (b) (1988). Once adopted, the forest plans can be amended only by complying with the same NEPA requirements governing adoption of the plans in the first instance. 16 U.S.C. $\$ 1604(\mathrm{f})(4),(\mathrm{g})(1)$. See Wilkinson \& Anderson, supra note 4, at 74.

218. See, e.g., Flathead Forest Plan Appeal Decision, supra note 188, at 4-9:

An LRMP puts in place a dynamic management system for future decisionmaking. It establishes goals and objectives for forest management, and standards and guidelines for management activities. It establishes rules for making future decisions about the management of the national forest. An LRMP, however, does not make most of these decisions. ...

LRMPs must not be regarded as collections of 10 to 15 years worth of project decisions which create irretrievable commitments of natural resources. . . .

The LRMP and FEIS set the stage for project or activity review but do not provide the last word.

See also Appeal of the Shoshone National Forest Land and Resource Management Plan, U.S. Forest Service No. 1552, 5.6 (Dec. 6, 1988) ("[N]o project or activity level decisions involving oil and gas leasing have been made in the LRMP. . . . [T]his does not mean that oil and gas leasing would no longer be considered on these [Grizzly Bear Situation One] lands.").

219. See, e.g., Mining Law of 1872, 30 U.S.C. $\$ \S 22-54$ (1982); Mineral Leasing Act of 1920, 30 U.S.C. $\S \S 181-287$ (1982 \& Supp. V. 1987); Geothermal Steam Act of 1970, 30 U.S.C. $\S \S 1001-1025$ (1982 \& Supp. V 1987); Endangered Species Act, $\S \S 1531-1543$ (1982); Clean Water Act of 1977, 33 U.S.C. $\$ \S 1251-1387$ (1982 \& Supp. V 1987). And beyond these federal laws, the Supreme Court in California Coastal Commission v. Granite Rock Co., 480 U.S. 572 (1987), upheld the authority of the states to impose additional environmental permitting requirements on development proposals involving national forest lands, so long as the state does not effectively "veto" the project. Id. at 586-87. 
cupies a unique position among these laws because it requires forest managers to review their multiple-use policy options against the backdrop of their environmental protection responsibilities. ${ }^{221}$ While the courts have concluded that NEPA is primarily a procedural statute and does not obligate agencies to choose the environmentally preferable alternative, they have utilized the implementing regulations to read rigorous procedural requirements into the statute. ${ }^{222}$ According to these regulations, NEPA obligates federal agencies to examine the impact that proposed activities would have on neighboring lands, ${ }^{223}$ to consult with other agencies and involve them in the NEPA review process, ${ }^{224}$ to assess the cumulative impacts accompanying specific proposals, ${ }^{225}$ and to consider mitigation measures. ${ }^{226}$ Thus, NEPA, like the ESA and the NFMA, is not boundary-limited, and the judicial gloss the statute has acquired makes it a powerful tool for assuring that the Forest Service takes account of its neighbors and other resource values when weighing multiple-use development proposals. ${ }^{227}$

Most forest plans in the Yellowstone region are under administrative appeal. In general, the Forest Service has taken the position that consumptive-use activities ordinarily should be permitted on multipleuse lands so long as irreversible environmental damage can be avoided

220. 42 U.S.C. $\$ \$ 4321-4370$ (1982).

221. NEPA provides that federal agencies contemplating actions "significantly affecting the quality of the human environment" are to prepare an environmental impact statement (EIS) evaluating the environmental effects of the proposal and alternative courses of action. 42 U.S.C. $\$ 4332(2)(C)$.

222. Strycker's Bay Neighborhood Council v. Karlen, 444 U.S. 223 (1980); Kleppe v. Sierra Club, 427 U.S. 390, 410 n.21 (1976); California v. Block, 690 F.2d 753, 761 (9th Cir. 1982).

223. 40 C.F.R. $\$ 1508.27$ (b)(3) (1988). Glacier-Two Medicine Alliance, 88 IBLA 133, Gower's Fed. Serv. (O\& G) 108 (1985).

224. 40 C.F.R. $\$ 1501.6$ (1986). See Mardis v. Big Nance Creek Water Management Dist., 578 F. Supp. 770,787 (N.D. Ala. 1983). Moreover, NEPA provides a referral procedure to the Council on Environmental Quality for resolving interagency disagreements. 40 C.F.R. $\S 1504$ (1982). But the federal agencies do not ordinarily resort to this procedure. They are reluctant to air their disputes publicly and to allow decision-making authority to slip from their hands, even if only for a recommendation. But see Sierra Club v. United States Dep't of Transp., 753 F.2d 1209 (D.C. Cir. 1985); National Wildlife Fed'n v. Goldschmidt, 504 F. Supp. 314 (D. Conn. 1980), aff'd, 677 F.2d 259 (2d Cir. 1982).

225. 40 C.F.R. $\$ \S 1508.2 S(a)(2), 1508.7$. See Kleppe v. Sierra Club, 427 U.S. 390 (1976); Thomas v. Peterson, 753 F.2d 754 (9th Cir. 1985); Fritiofson v. Alexander, 772 F.2d 1225 (5th Cir. 1985); National Wildlife Fed'n v. United States Forest Serv., 592 F. Supp. 931, 942-44 (D. Or. 1984).

226. 40 C.F.R. $\$ \S 1502.14$ (f), 1502.16(h), 1508.20 (1987). Methow Valley Citizens Council v. Regional Forester, 833 F.2d 820 (9th Cir. 1987) (holding that an EIS must implement a feasible mitigation plan), rev'd sub nom. Robertson v. Methow Valley Citizens Council, 109 S. Ct, 1835 (1989) (concluding that NEPA requires only consideration of mitigation measures).

227. However, the environmental analysis underlying the forest plans may minimize agency obligations under laws such as NEPA when they are called upon to evaluate the impact of particular future projects. Cf. Park County Resource Council v. United States Bureau of Land Management, 638 F. Supp. 842, 845 (D. Wyo 1986) (relying upon the forest plan in conjunction with an environmental assessment to find no NEPA violation). See S. Mealey, Evaluation of the Use of Forplan in Management Planning on the Shoshone National Forest (Nov. 4, 1986). 
through mitigation, restrictive stipulations, or otherwise, and if statutory environmental protection standards can be satisfied. ${ }^{228}$ Most of the forest plans provide for extensive timber harvesting ${ }^{229}$ as well as oil and gas leasing on nonwilderness forest lands. ${ }^{230}$ Road construction is expected to increase significantly the road mileage in most of the forests. $^{231}$ No forest has specifically precluded consumptive-use activities on lands adjacent to national parks or wilderness areas. The plans for the Montana and Idaho forests have recommended limited acreage for wilderness designation, omitting undisturbed lands located near park and wilderness boundaries, as well as important wildlife habitat. ${ }^{232}$

While there are predictable similarities among the plans, there are also striking differences in how individual forests manage sensitive areas and resources. The recently completed Greater Yellowstone Area Aggregation Report reveals, for example, that the Targhee National Forest is doing extensive clearcutting adjacent to Yellowstone National Park, while the other forests contemplate only modest logging

228. See, e.g., Gallatin Forest Plan, supra note 163, at II-1 to -7; U.S. Forest Serv., DeP'T of Agric., Beaverhead National forest Plan Record of Decision 7 (1986).

229. See, e.g., Gallatin Forest Plan, supro note 163, at II-5, III-42, -43; Gallatin Forest PLAN FEIS, supra note 20, at B-107 (approximately 21 million board feet (MMBF) will be offered annually for timber harvest during the first decade, representing a 3-MMBF increase from the past decade; 14 MMBF will come from current roadless lands); TARGHEE ForEST PLAN, supra note 111, at 97, 100, 677-87 (projecting timber sales ranging from $110 \mathrm{MMBF}$ to $70 \mathrm{MMBF}$ during the first decade of the plan, which represent a steady increase from the pre-1980 sales volume); CUSTER FOREST PLAN FEIS, supra note 163, at 43, 212 (preferred alternative would allow 3.0 MMBF of annual timber harvest; present level is 1.5 MMBF annually). In general, the Targhee National Forest's timber sales volume far exceeds that of any other regional forest, owing largely to the diseased condition of the forest. See also AGgREgation REPORT, supra note 14, at 3-79.

230. See, e.g. CUSTER Forest Plan FEIS, supra note 163, at 128 (1.77 million acres, or $84 \%$ of the lands administered by the Custer National Forest, excluding the Absaroka-Beartooth Wilderness, under lease on Apr. 24, 1986); Gallatin Forest Plan, supra note 163, at D-1 (noting that 30\% of the forest is currently leased or under lease application); GALLATIN Forest PLAN FEIS, supra note 20. at 1I-36 ("very little land outside wilderness . . would not be available for leasing and exploration"); 1 ShOShONe FOREST PLAN FEIS, supra note 163, at III-62 (approximately 934,000 of 1,054,000 acres of nonwilderness forest lands are available for leasing); Draft Final Bridger-TETON Forest PLAN EIS, supra note 78, at Summary-1 (reporting that the final Bridger-Teton Forest Plan will make 1.56 of the 1.84 million acres of nonwilderness lands available for leasing, but will impose a "no surface occupancy" restriction on 1.17 million acres primarily to protect steep slopes). See also AGgregation REPORT, supra note 14, at 3-97,-100,-105 (map 33); SIERRA ClUB, supra note 21, at 6.

231. CUSTER FOREST PLAN FEIS, supra note 163, at 60 (3803 miles of road in 1980; preferred alternative anticipates 5650 miles of road); GALLATIN FOREST PLAN FEIS, supra note 20, at IV-58 (preferred alternative would increase the total roads from about 800 miles to 2310 miles); DRAFT FI. NAl BRIDGer-Teton Forest Plan EIS, supra note 78, at Summary-2 (approximately $\mathbf{4 0 0}$ miles of new roads would be constructed in the first five decades under the plan but road closures would reduce open roads by approximately 600 miles over 50 years). But see Shoshone Forest PLAN FEIS, supra note 163, at II-29 (preferred alternative will allow for a net increase of 14 additional miles of roads in the next 10 years).

232. See text at notes 291-301, infra, for a description of the wilderness designation controversy. 
on lands bordering the Park. ${ }^{233}$ Two forest plans-the Shoshone and Custer-have placed critical grizzly bear lands off-limits to mineral exploration, ${ }^{234}$ and the Shoshone and Bridger-Teton plans contain reduced timber harvest expectations. ${ }^{235}$ At one level, these inconsistencies reflect the autonomy and discretionary authority individual forest managers enjoy, as well as the sensitivity of each to local public preferences. At another level, however, such inconsistencies reveal just how fragmented management is throughout the region, and call into question the seriousness of the Forest Service's commitment to coordinated management when it threatens the agency's traditional multiple-use agenda. A closer look at the timber harvesting, oil and gas leasing, and wilderness controversies illustrates the conflicting pressures confronting the agency, as well as how litigation and legislation have influenced these matters.

\section{Timber: Slipping from Dominance?}

Timber harvesting controversies abound on the national forests in the Yellowstone region. On the one hand, environmentalists complain that the Forest Service's harvest quotas far surpass reasonable levels, given the environmental damage that clearcut logging causes, particularly on roadless lands providing important wildlife habitat, and the negative economic returns from most sales. ${ }^{236}$ On the other hand, communities such as Dubois, Wyoming, have long depended upon public timber to sustain local mills and jobs, and the timber companies believe downward harvest revisions threaten their very survival. ${ }^{237}$ Long regarded as an agency committed primarily to timber production, the Forest Service has taken the position that logging is appropriate so long as basic NFMA environmental protection requirements

233. AGgRegation RePORT, supra note 14, at 3-87 (map 29). See also supra notes 111, 229.

234. See supra note 163 and accompanying text. See also supra note 112 (noting the BridgerTeton's unique no-leasing buffer zone proposal adjacent to Grand Teton National Park that has been dropped from the final forest plan).

235. Shoshone Forest Plan FEIS, supra note 163, at II-55, A-1 to A-12 (reducing timber sales from 11.8 MMBF to 10.5 MMBF annually); Draft FinAl Bridger-Teton Forest Plan EIS, supro note 78, at 2-83 (reducing timber harvesting from 17 MMBF to 12 MMBF annually); AGgregATION REPORT, supra note 14, at 3-79.

236. See Gallatin Forest Plan Appeal, supra note 195, at 34-101. See also U.S. Forest SERV., Dep't of Agric., Timber Sale Program anNual. Report, Fiscal Year 1987 Test, Forest LEVEL INFORMATION 4-5, 15, 30-32 (showing net revenue losses for six of the seven Yellowstone area forests; the Caribou National Forest showed a small positive revenue return); ECONOMIC DATABASE, supra note 44, at 6 (concluding that net timber receipts for all six Yellowstone area forests are negative); CRS EcosySTEM REPORT, supra note 14, at 74 (noting that for fiscal years 1983-85 the federal government spent $\$ 11.34$ million on timber sales but received only $\$ 5.81$ million in cash receipts).

237. See Intermountain Forest Indus. Ass'n v. Lyng, 683 F.Supp. 1330 (D. Wyo. 1988); 2 SноShONe Forest Plan FEIS, supra note 163, at VI-14 to-17. See also G. REYNOLdS, supra note 25, at 52.55. 
can be met, and it defends clearcutting as a beneficial forest management practice. ${ }^{238}$ The forest plans generally show timber harvesting continuing at, or exceeding, present levels, ${ }^{239}$ and provide that lands located near the national parks and those providing important wildlife habitat, such as the Mt. Leidy Highlands and the southern portion of the Gallatin Range, will be open to logging.

In the Bridger-Teton National Forest, controversy has focused on timber management policies in the vicinity of Dubois, where the Forest Service's extensive past timber sales program has severely depleted the current timber supply. When the Forest Service, to protect diminishing elk habitat, did not schedule any new timber sales in the area, local timber interests-principally the Louisiana-Pacific Corporation-objected that the lack of timber would compel them to shut down their operations and dismiss their workforce. ${ }^{240}$ Seeking access to additional timber, the Intermountain Forest Industry Association and Louisiana-Pacific sued the Forest Service alleging that it was legally obligated to make more timber available under its existing timber management plan. ${ }^{241}$ Moreover, the industry asserted that the Forest Service must give precedence to timber resources over other forest resources to maintain local community stability. ${ }^{242}$ In Intermountain Forest Industry Association v. Lyng, ${ }^{243}$ however, a Wyoming federal district court rejected these arguments, finding that the Forest Service's organic mandate does not give timber priority over other resources, and that neither the organic legislation nor the agency timber plans vested any access rights in the logging company. ${ }^{244}$ The court, in effect, concluded that timber harvesting decisions rested with the agency, a ruling that confirmed the Forest Service's discretionary au-

238. Clearcutting, according to the Forest Service, can enhance wildlife habitat, limit insect damage, and help control forest fires. ShOShONe Forest PLAN FEIS, supra note 163, at I1-53 to -54. See also G. Coggins \& C. Wilkinson, Federal Public land and Resources Law 619-20 (2d ed. 1987).

239. See supro note 229.

240. The Forest Service reduced timber harvest levels to protect other resources, namely to secure elk habitat that was being lost due to extensive prior logging activity and to protect unstable lands from erosion. Intermountain Forest Indus. Ass'n v. Lyng, 683 F. Supp. 1330, 1333-35 (D. Wyo. 1988).

241. Id. at 1332.

242. Sustained-Yield Forest Management Act of 1944, 16 U.S.C. $\$ \S 583,583 \mathrm{a}-\mathrm{i} ; 43$ U.S.C. $\S 1181$ (a) (1982). See 36 C.F.R. $\$ 221.3(a)(3)$ (1988). The timber industry argued that the language of the statute $(\$ 583 \mathrm{~b})$ and the regulation requires the timber resource to be the primary management goal of the forest if it is necessary to strengthen and stabilize a local economy. See also Comment, supra note 139, at 411, 429; Schweitzer \& Risbrudt, How National Forest Planning Addresses Community Stability, Renewable Resources J., Spring 1988, at 4-9.

243. 683 F. Supp. 1330 (D. Wyo. 1988).

244. Id. at 1338, 1340. Respecting the 1944 Sustained-Yield Forest Management Act local community stability argument, the court found the statutory language was discretionary not mandatory. Id. at 1339 . 
thority to curb logging to protect wildlife habitat and other ecological values.

The same result obtained in earlier litigation involving LouisianaPacific's efforts to keep its Dubois mill afloat. Louisiana-Pacific had sought access to the still largely unharvested upper Green River drainage, which lies across the Continental Divide from Dubois and is readily accessible only by a poorly constructed dirt road known as the Union Pass Road. Environmentalists, local ranchers, and outfitters objected that upgrading the road to accommodate logging trucks would increase traffic, create conflicts with wildlife, and encourage logging in a portion of the forest valuable for other purposes, namely wildlife habitat, primitive recreation, and hunting. Three separate lawsuits were filed challenging the Forest Service's authority over the Union Pass road, and indirectly raising the question of the propriety of logging in this area. ${ }^{245}$ In all three cases, federal courts sustained the Forest Service's authority over the road, ${ }^{246}$ thus leaving final resolution of the matter in the agency's hands and, in essence, preserving an unlogged watershed. ${ }^{247}$

Elsewhere in the Greater Yellowstone national forests, however, timber production continues to be a major focus of the Forest Service's multiple-use agenda. Although the Bridger-Teton is not selling timber around Dubois, it does contemplate additional logging in the southern reaches of the forest where Afton and other towns support a sizeable logging industry, and where conflicts with recreational interests are less apparent. ${ }^{248}$ Timber harvesting in the Targhee National Forest occurred at high levels during the past decade and will continue running high. ${ }^{249}$ The Gallatin and Custer forests also plan to increase

245. Mountain States Legal Found. v. Robertson, No. C87-0274-B (D. Wyo. Oct. 19, 1987); Wyoming Outdoor Council v. Peterson, No. C86-208J (D. Wyo. July 16, 1986), Retel v. Peterson, C86216-B (D. Wyo. June 27, 1986).

246. In Mountain States Legal Foundation v. Robertson, the court held that even if the public acquired an easement over public property through use, this easement does not preclude government regulation of the property, including restricting motorized use. Slip op. at 12 . In Wyoming Outdoor Council $v$. Peterson, the court held that issues of harm to the environment were addressed in the biological assessment, and the Forest Service has the authority to control multiple-use activities on forest lands. Slip op. at 11.

247. According to the Forest Service, the decision whether to permanently upgrade the road will be made in the forest planning process. In the meantime, the town of Dubois has begun efforts to bolster its image as a year-round resort community, and it has joined with the towns of Jackson and Pinedale to study the feasibility of maintaining the Union Pass Road to link these towns together through a scenic traffic loop for tourists. The Forest Service has granted $\$ 75,000$ to the towns of Dubois and Cody, Wyoming, to enable town officials to examine ways to diversify their local economies. Casper Star Trib., Oct. 10, 1988, at BI.

248. Bridger-Teton Draft Forest Plan, supra note 112, at II-5. See also note 235, supra, reflecting a 5-MMBF annual timber sale reduction in the Bridger-Teton National Forest plan.

249. Aggregation Report, supra note 14, at 3.79; TARghee Forest Pl.AN, supra note 111, at 
their timber production. ${ }^{250}$ Although the Dubois litigation indicates that the courts are reluctant to displace the Forest Service's authority over timber management decisions, there most likely will be further litigation over this issue under the NFMA. ${ }^{251}$ Environmentalists have challenged the Forest Service's timber harvesting objectives in each forest plan, arguing that the agency has violated substantive NFMA constraints by, for instance, sanctioning logging on physically unsuitable lands and using clearcutting when it is not the optimum harvest method. ${ }^{252}$ If the courts are willing to read meaningful, substantive limits into the yet-uninterpreted NFMA and to constrain the Forest Service's timber harvesting plans, this could effectively displace timber as a dominant use of Yellowstone area forests. Of course, the Forest Service also has the inherent authority under the Intermountain Forest Industry precedent to reorder its own priorities to enhance and protect resources other than timber.

\section{Oil and Gas: Moving Up on the Agenda?}

The most extensively litigated issue in the Yellowstone region is the question of oil and gas activity on multiple-use forest lands, ${ }^{253}$ particularly those that are undisturbed or located in ecologically sensitive areas. $^{254}$ Nearly half of the forests already are leased, and the forest

97, 100, 677-87. See ForESTS OF THE FUTURE?, supra note 199, at 52 (noting a $29 \%$ increase in the harvest level during the first decade).

250. See supra note 229.

251. While the timber industry remains displeased with the Forest Service's revised timber quotas, it will have difficulty surmounting the adverse precedent established in Intermountain Forest Industry Association v. Lyng, 683 F. Supp. 1330 (D. Wyo. 1988). See Decision, Appeal of the Shoshone National Forest Land \& Resource Management Plan, U.S. Forest Service No. 1553, 2-5 (Oct. 14, 1988) (rejecting the claim that the forest plan illegally deemphasizes timber production).

252. 16 U.S.C. $\S 1604(\mathrm{~g})(3)(\mathrm{E})(1982)$; id. $\$ 1604(\mathrm{~g})(3)(\mathrm{F})$. See, e.g., Gallatin Forest Plan Appeal, supra note 195, at 73-89, 94-101 (Statement of Reasons).

253. Until Congress revised onshore oil and gas leasing procedures in the Federal Onshore Oil and Gas Leasing Reform Act of 1987, 30 U.S.C. $\$ 226(\mathrm{~h})$ (Supp. V 1987), the Forest Service and the Bureau of Land Management shared responsibility for mineral exploration on forest lands. The BLM retained the ultimate authority to authorize or deny lease and permit applications, 43 C.F.R. $\$ 3101.1$ (1987), while the Forest Service was responsible for surface resources. 36 C.F.R. $\$ 200.3(2)$ (1988). Ordinarily, the Forest Service took the lead in preparing NEPA analyses, and its recommendations on leasing and exploration were consistently followed by the BLM. See Wilkinson \& Anderson, supra note 4, at 262; Custer Forest Pl.AN FEIS, supra note 163, at 178; Oversight Hearing, supra note 15, at 57. Therefore, this article will refer to the Forest Service as the agency responsible for oil and gas decisions on forest lands, though the BLM technically had final authority over these matters. Now, however, under the Leasing Reform Act of 1987, the Secretary of the Interior may not lease national forest lands if the Secretary of Agriculture objects.

254. The oil industry perceives very high potential for oil and gas discoveries in the Overthrust Belt area, which includes most of the Bridger-Teton National Forest and Shoshone National Forest in Wyoming and extends into the Gallatin, Custer, and Beaverhead forests in Montana. Mountain States Legal Found. v. Andrus, 499 F. Supp. 383, 386-87 (D. Wyo. 1980); Conner v. Burford, 848 F.2d 1441. 
plans uniformly call for extensive additional leasing. ${ }^{255}$ Once forest lands have been leased, the Forest Service never has refused an exploratory drilling permit application, taking the position that the lease conveys a property right insuring leaseholders the opportunity to explore for oil and gas. ${ }^{256}$ Yet according to one Forest Service document:

The activities associated with minerals and energy resources are generally in contrast to the "natural" values of the Greater Yellowstone Ecosystem. While mitigation measures can often be applied at the exploration phase of oil and gas activities, the potential of a developed field, with pipelines, potential sweetening plants, associated increased population, as well as resource impacts, would significantly reduce the values in the "Ecosystem." 257

With big money at stake and the specter of environmental catastrophe looming, the Forest Service's leasing decisions have caught the agency in the cross-fire of litigation. In one series of cases, environmentalists have challenged forest leasing programs, arguing that leasing is the critical stage in the oil and gas development process and that NEPA requires full environmental analysis of the potential impacts before a decision to lease is made. ${ }^{258}$ The Forest Service has taken the position, however, that the NEPA process is appropriately segmented because there is no assurance any lease will be explored; thus, full-field development analysis at the leasing stage is meaningless until exploration information is available. ${ }^{259}$ In another series of cases, the Forest Service has been forced to defend its policy of delaying processing certain lease applications for roadless lands against claims by the oil industry that mineral leasing is entitled to priority under federal laws promoting mineral exploration on the public lands. ${ }^{260}$ As we shall see,

1443 (9th Cir. 1988), cert. denied sub nom. Sun Exploration \& Prod. Co. v. Lujan, 109 S. Ct. 1121 (1989); Custer Forest Plan FEIS, supra note 163, at 179.

255. See supra note 230 and accompanying text.

256. Oversight Hearing, supra note 15, at 67 (testimony of Max Peterson, Forest Service Chief). See Sierra Club v. Peterson, 717 F.2d 1409, 1411 (D.C. Cir. 1983); Conner v. Burford, 848 F.2d at 1450. See also Union Oil Co. v. Morton, 512 F.2d 743, 748-49 (9th Cir. 1975). See generally Laitos \& Westfall, Government Interference with Private Interests in Public Resources, 11 HARV. ENVTL. L. REV. 1 (1987).

257. BRIDGER-TETON DEIS, supra note 68, at IV-107.

258. In general, mineral development is a staged or segmented activity. It begins with oil companies seeking leases and conducting seismic testing, and proceeds to exploratory drilling on promising sites, production and full field development in the event of a strike, and finally reclamation after the field is exhausted. See Sierra Club v. Peterson, 717 F.2d at 1411-12, for a description of the oil and gas development process.

259. Frequently cited statistics suggest that exploration occurs on only $10 \%$ of the leases, and that oil is discovered and development ensues in less than $10 \%$ of the wells drilled. Park County Resource Council v. United States Dep't of Agric., 817 F.2d 609, 623 (10th Cir. 1987).

260. See Mountain States Legal Found. v. Hodel, 668 F. Supp. 1466 (D. Wyo. 1987); Mountain 
the various holdings in these cases send mixed signals about the priority of oil and gas activity in the national forests.

Three federal appellate courts have reached quite different results on the question of what NEPA environmental review procedures the Forest Service must follow before issuing a mineral lease in the Greater Yellowstone region. The D.C. Circuit Court of Appeals, in Sierra Club v. Peterson, ${ }^{261}$ held that NEPA required the Forest Service to prepare an EIS evaluating the environmental impact of exploratory drilling before leasing roadless forest lands in the Bridger-Teton $\mathrm{Na}$ tional Forest not protected by a "no surface occupancy" (NSO) clause. $^{262}$ In Park County Resource Council v. United States Department of Agriculture, ${ }^{263}$ however, the Tenth Circuit sustained a Forest Service decision to issue leases on Shoshone National Forest lands without first preparing an EIS addressing the environmental impacts that drilling and future development might have on forest resources. $^{264}$ Noting the speculative likelihood of exploration, the court described leasing as "a paper transaction" that "does not cause a change in the physical environment," 265 and thus authorized a segmented environmental review process. In contrast, in Conner v. Burford, ${ }^{266}$ which involved leasing on the Gallatin National Forest, the Ninth Circuit ruled that NEPA obligated the Forest Service to prepare an EIS before leasing any forest lands when surface-disturbing activities were not precluded by lease stipulations. The court viewed the leasing stage as the critical juncture in the oil and gas development process, and held that the EIS must address the potential of fullfield development. ${ }^{267}$ While these cases may be distinguished factu-

States Legal Found. v. Andrus, 499 F. Supp. 383 (D. Wyo. 1980). Both cases are discussed in the text at notes $269-76$ infra.

261. 717 F.2d 1409 (D.C. Cir. 1983).

262. Id. at 1414-15. The decision, therefore, preserved the undisturbed character of these lands until the Wyoming wilderness bill was acted upon by Congress. A no-surface-occupancy clause on a lease "precludes surface occupancy unless and until such activity is specifically approved by the Forest Service." Id. at 1411 (emphasis in original). It conveys a priority right, not a property right.

263. 817 F.2d 609 (10th Cir. 1987). Notably, the Tenth Circuit did not even cite the D.C. Circuit's Sierra Club v. Peterson ruling in its opinion.

264. Id. at 623. The Forest Service in Park County had merely prepared an environmental assessment, which is a less rigorous review document than an environmental impact statement, and which is often used as a preliminary basis for deciding if an EIS is warranted. See 40 C.F.R. $\$ 1508.9(1)(1988)$.

265. 817 F.2d at $621-22$.

266. 848 F.2d 1441 (9th Cir. 1988), cert. denied sub nom. Sun Exploration \& Prod. Co. v. Lujan, 109 S. Ct. 1121 (1989). Besides addressing the question of leasing in the Gallatin National Forest, Conner also addressed this question for the Flathead National Forest in northwestern Montana.

267. Id. at 1451. The court also ruled that the Fish and Wildlife Service could not segment its biological review obligations under the Endangered Species Act; it was legally required to assess the impact that oil and gas exploration might have on the grizzly bear, even though it did not know exactly where drilling might occur. Id. at 1452-53. See also supra text at note 171 . 
ally, ${ }^{268}$ the results of the rulings are strikingly anomalous: The Forest Service must prepare a comprehensive EIS at the leasing stage for forests in Montana and Idaho, but not before leasing in Wyoming's Bridger-Teton and Shoshone National Forests.

Recognizing the volatility of the leasing issue, the Forest Service twice has delayed processing lease applications in the Greater Yellowstone region-once to complete its wilderness review process and again to complete the NFMA forest-planning process. In each instance, however, the agency was sued successfully by the oil and gas industry and ordered to process pending applications. In Mountain States Legal Foundation v. Andrus, ${ }^{269}$ the district court held that the Forest Service violated the Federal Land Policy and Management Act (FLPMA) ${ }^{270}$ by effectively "withdrawing" from mineral exploration portions of its roadless forest lands in Wyoming, Idaho, and Montana, pending completion of its wilderness review. ${ }^{271}$ In essence, the court concluded that the mineral development policy expounded in the Mineral Leasing Act of $1920^{272}$ took precedence over the Forest Service's wilderness planning obligations. ${ }^{273}$ Similarly, when the Forest Service

268. The principal factual distinction is that, in Park County, the Wyoming wilderness review process was complete and the lands leased had been "released" from inclusion in the wilderness system; but in the other two cases, the wilderness review process was ongoing and some of the leased lands were eligible for inclusion in the wilderness system. See Mansfield, Through the Forest of the Onshore Oil and Gas Leasing Controversy Towands a Paradigm of Meaningful NEPA Compliance, 24 LAND \& WATER L. REv. 85, 110-13 (1989). But see Conner v. Burford, 848 F.2d at 1448 n.17 (rejecting any distinction between roadless and nonroadless lands for NEPA purposes).

269. 499 F. Supp. 383 (D. Wyo. 1980).

270. 43 U.S.C. $\$ \S 1701-1784$ (1982).

271. The court held the lease review suspension was within the definition of a "withdrawal" under 43 U.S.C. $\$ 1702(j)$, which requires the agency to follow the procedures of 43 U.S.C. $\$ 1714(c)$. 499 F. Supp. at 391 . Because these provisions limit the authority of the Secretary of the Interior and the Secretary of Agriculture to withdraw large tracts of public land, the withdrawal constituted an abuse of discretion. Id. at 395. However, the court did not order any particular action on the leases; it merely ordered the agencies to notify Congress of the withdrawal, or to begin processing the lease applications. Id. at 397. It did not order the agencies to grant leases, nor did it preclude them from attaching stipulations to the leases.

272. 30 U.S.C. $\$ \S 181.287$ (1982).

273. 499 F. Supp. at 342 . Significantly, the court overlooked an important congressional policy when it did not cite any statutory basis for the Forest Service's wilderness planning authority. It relied solely upon the Mineral Leasing Act to divine Congress's policy preferences. But Congress plainly included wilderness evaluation among the Forest Service's NFMA planning responsibilities when it included "wilderness" as one element of the forest plans, thus legitimating wilderness as a coequal use among the multiple uses of the forests. 16 U.S.C. $\$ 1604(\mathrm{e})(1)$. In 1982, two years after this litigation, the Ninth Circuit put "teeth" in the NFMA wilderness planning provision when it sustained a lower court decision enjoining further roadless area development pending completion of an adequate EIS evaluating those lands for wilderness suitability. California v. Block, 690 F.2d 753 (9th Cir. 1982), aff'g California v. Bergland, 483 F. Supp. 465 (E.D. Cal. 1980). In the recent Federal Onshore Oil and Gas Leasing Reform Act, Congress endorsed this position by precluding leasing of recommended wilderness lands. 30 U.S.C. § 226-3 (Supp. V 1987). See generally Brooks, Multiple Use versus Dominant Use: Can Federal Land Use Planning Fulfill the Principles of Multiple Use for Mineral Development?, 
ceased reviewing lease applications for the Bridger-Teton National Forest in order to complete the forest plan, the district court in Mountain States Legal Foundation v. Hodel ${ }^{274}$ found the suspension violated the 1980 Energy Security Act, ${ }^{275}$ as well as the FLPMA "withdrawal" provisions. ${ }^{276}$ In both cases, the courts rejected the Forest Service's argument that it enjoyed discretion to defer leasing until it had determined whether leasing was consistent with its other management obligations. Instead, the courts derived from FLPMA and the mineral leasing and energy acts a strong congressional intent to promote mineral development, and they concluded that these laws limited the agency's discretionary powers.

Because these two rulings have the effect of accelerating the lease review process, the decisions can be understood to give mineral activity something of a dominant priority-at least in Wyoming-among the multiple uses sanctioned on the public lands. But the rulings have no precedential value elsewhere in the Greater Yellowstone region. In other litigation the Ninth Circuit has rejected the Wyoming courts' reasoning and sustained the Forest Service's discretionary authority over mineral leasing on national forest lands. ${ }^{277}$ Besides, the NEPA injunctions, though procedural in nature, have the effect of slowing the leasing process, and they require the agencies to undertake extensive environmental analysis before any leases are issued. Moreover, the Wyoming "withdrawal" rulings do not obligate the Forest Service to issue leases, nor do they preclude it from utilizing restrictive lease stipulations to protect environmentally sensitive lands. Indeed, virtually all of the Greater Yellowstone forests have placed some restrictions on oil and gas leases, and two forests have precluded leasing on critical grizzly bear lands. ${ }^{278}$

In the aftermath of these decisions, the Forest Service is reviewing its leasing policy on the Bridger-Teton National Forest, where its decisions are being closely monitored because they promise to establish precedent-setting standards. Significantly, rather than relying

\footnotetext{
33 RockY MTN. MIN. L. INST. 1-1, 1-12 to -19 (1988) (arguing that mineral development should be treated as a priority use on multiple-use lands).

274. 668 F. Supp. 144 (D. Wyo. 1987).

275. 30 U.S.C. $\$ \S 1601-1605$ (1982).

276. 43 U.S.C. $\$ 1714$ (1982).

277. Bob Marshall Alliance v. Hodel, 852 F.2d 1223, 1230 (9th Cir. 1988) cert, denied sub nom. Kohlman v. Alliance, 109 S. Ct. 1340 (1989). In rejecting the argument that deferring action on the leases at issue would have constituted an illegal administrative "withdrawal," the court concluded that the Secretary of the Interior has discretion whether to issue leases on the public lands. See also Burglin v. Morton, 527 F.2d 486, 488 (9th Cir. 1975), cert. denied, 425 U.S. 973 (1976).

278. See, e.g., Custer Forest Plan, supra note 230, at 169-73. See also supra notes 163, 234 and accompanying text.
} 
upon a Park County-sanctioned environmental assessment, forest officials are undertaking a full NEPA analysis of the environmental effects of mineral leasing. ${ }^{279}$ This move, however, represents merely a procedural revision of agency policy, and it only delays what ultimately will be a broad-scale leasing program. Already Bridger-Teton officials have proposed leasing more than ninety-five percent of the southern portion of the forest, ${ }^{280}$ and they apparently will also open the northern portion of the forest to leasing while dropping proposed "no leasing" restrictions on critical grizzly bear lands and on lands near Grand Teton National Park in the final forest plan. ${ }^{281}$ Utilizing its discretionary leasing authority, the Forest Service seems committed to allowing oil and gas activity throughout the Yellowstone region forests, restrained only by NEPA procedural requirements and the leasing stipulations it is willing to impose. But these constraints are actually rather illusory. The NEPA reviews have rarely precluded leasing, ${ }^{282}$ stipulations can be modified, ${ }^{283}$ and even forest plan leasing

279. In the Bridger-Teton forest plan, forest officials have attempted to predict the impacts of fullfield development in the event of a "strike," thus meeting a continuing objection of the environmental community to the NEPA review process. See Draft Final Bridger-Teton Forest Plan EIS, supra note 78, at 201-04, 738-40. See also Casper Star Trib., June 26, 1988, at A1. According to the Forest Service, this approach was prompted by continuing public concern over oil and gas leasing in the Jackson Hole vicinity, as well as concern over wildlife resources and local economic impacts. Casper Star Trib., Dec. 24, 1987, at B1; id., May 28, 1988, at A1. However, the Forest Service has taken the position that it has no authority to cancel an already granted lease when an EIS was not prepared prior to leasing. U.S. Bur. OF LAND MANagement, Dep't of the INTERIOR \& U.S. Forest SERv.,

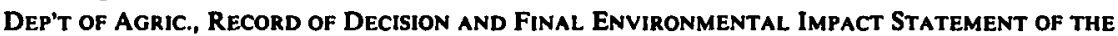
Sohare Creek Unit Exploratory OIL Well No. 1-35, at 188 (1988) [hereinafter Sohare FEIS].

280. See U.S. Forest Serv., Dep't of Agric. \& Bureau of Land Management, U.S. Dep't of THE INTERIOR, ENVIRONMENTAL ASSESSMENT, OIL AND GAS LEASING IN THE WeST BRIDGer AREA Of THE Bridger-Teton NATIONAL Forest 6 (Feb. 12, 1988). Under the proposed alternative, 977,611 acres of forest land would be available for mineral leasing (some with restrictive stipulations), and 1327 acres would be withdrawn from leasing.

281. Draft Final. Bridger-Teton Forest Plan EIS, supra note 78, at Summary-1, 743-44. See supra notes 112, 163. See also U.S. News \& Worlo RePORT, Aug. 29/Sept.5, 1988, at 92; Casper Star Trib.; Oct. 27, 1988, at A1. But see supra note 230 (explaining that Bridger-Teton officials will rely on NSO stipulations to protect steep slope forest lands).

282. See supra note 230 and text accompanying notes $279-81$.

283. See 36 C.F.R. $\$ 226.104$ (proposed), noted in 54 Fed. Reg. 3325, 3333 (1989); SoHARE FEIS, supra note 279 , at 1, 8.9 (modifying a "no surface occupancy" stipulation to authorize drilling). The question of what authority the government retains to protect its lands once a lease is issued, even when the lease contains stipulations to limit or control surface-disturbing activities or to protect surface resources, is a highly uncertain area of the law. See Sierra Club v. Peterson, 717 F.2d 1409, 1414 (D.C. Cir. 1983); Conner v. Burford, 848 F.2d 1441, 1449-50 (9th Cir. 1988), cert. denied sub nom. Sun Exploration \& Prod. Co. v. Lujan, 109 S. Ct. 1121 (1989). Whether the government could (or, more importantly, would) be able to effectively enforce these stipulations in the event of a major strike is yet untested, as is the question whether it could preclude development at this stage. Environmentalists understandably are concerned that the momentum for development at that point would not favor the environment. Village of False Pass v. Clark, 733 F.2d 605, 619 (9th Cir. 1984) (dissenting opinion). 
withdrawals are subject to administrative reversal. ${ }^{284}$ The result is that national forest mineral leasing policy is being developed on an ad hoc basis that leaves the agency with maximum discretionary power. ${ }^{285}$

Congress obviously holds the "trump" card on this issue. Although the Federal Onshore Oil and Gas Leasing Reform Act of $1987^{286}$ grants the Forest Service control over mineral leasing on its own lands, Congress has thus far declined to legislate specific environmental review standards. ${ }^{287}$ This leaves the Forest Service, under the watchful eye of the courts, the task of establishing mineral leasing policy on the national forests. ${ }^{288}$ Given the intensive litigation on this issue in the Yellowstone region, it is not surprising that the Forest Service appears intent on implementing-both through its proposed regulations and its forest planning decisions-a mineral leasing policy that accentuates its discretionary authority and thus minimizes the likelihood of judicial intervention. ${ }^{289}$ But until Congress is convinced

284. See supra note 218 and accompanying text.

285. The actual extent of the Forest Service's discretionary authority over mineral development proposals is illustrated by several recent Yellowstone region cases in which the courts were asked to review the agency's exploratory drilling decisions. In all instances the courts have sustained these decisions against attack. See Getty Oil Co. v. Clark, 614 F. Supp. 904 (D. Wyo. 1985) (sustaining an IBLA decision requiring additional environmental analysis before permitting a well on Little Granite Creek in the Bridger-Teton National Forest, a location subsequently designated as wilderness by Congress), aff'd, 840 F.2d 776 (10th Cir. 1988); Park County Resource Council v. United States Dep't of Agric., 613 F. Supp. 1182 (D. Wyo. 1985) (Park County I) (sustaining against NEPA attack a Shoshone National Forest decision authorizing exploratory drilling on the basis of an EIS), aff'd on other grounds, 817 F.2d 609 (10th Cir. 1987); Park County Resource Council v. United States Bureau of Land Management, 638 F. Supp. 842 (D. Wyo. 1986) (Park County II) (sustaining against NEPA attack a Shoshone National Forest decision authorizing exploratory drilling on the basis of an environmental assessment prepared after the forest plan was completed). See also Sierra Club, 104 IBLA 76 (U.S. Dep't of the Interior, IBLA 88.442, Sept. 2, 1988) (sustaining a Forest Service decision approving Chevron's exploration permit application for Sohare Creek in the sensitive Mt. Leidy Highlands region of the Bridger-Teton National Forest despite alleged NEPA and ESA violations, thus opening to exploratory drilling forest lands located strategically in the midst of national park, wilderness, and wildlife refuge lands).

286. 30 U.S.C. $\$ 226($ h) (Supp. V 1987).

287. H.R. Conf. ReP. No. 495, 100th Cong., ist Sess. 779, reprinted in 1987 U.S. Code Cong. \& ADMIN. NewS 2313-1245, 2313-1525 (noting that the House provision requiring that oil and gas leasing be adequately evaluated on environmental grounds in land use plans prior to leasing was deleted by the Conference Committee amendment). However, Congress did direct the National Academy of Sciences and the Comptroller General to conduct a study of how oil and gas resources are addressed in the NFMA and FLPMA land use plans being adopted by the Forest Service and the BLM. See generally Cocgins \& WILKINSON, supra note 238, at 716-60, for a discussion of FLPMA and the BLM planning process.

288. Frustrated by their inability to secure any congressional action on the leasing question, environmental groups, led by the Sierra Club Legal Defense Fund and National Wildlife Federation, have announced they plan to challenge most upcoming oil and gas lease auctions in the western states on NEPA compliance grounds. Casper Star Trib., Sept. 10, 1988, at A1; id., Sept. 30, 1988, at Al.

289. This is illustrated by the Forest Service's approach to leasing in its proposed regulations. 54 
that a clear public consensus exists on this issue (and there is evidence of an emerging consensus in parts of the Yellowstone region), ${ }^{290}$ the agencies apparently will be left to chart their own course through this legal minefield. Aside from the restraints imposed by the Endangered Species Act and the temporary NEPA injunctions, there is little evidence that the law otherwise constrains leasing and exploration activity outside national parks and wilderness areas.

\section{Wilderness Designation: A Lingering Conundrum}

The wilderness issue remains unresolved for much of the Yellowstone region, as Congress has yet to enact a state wilderness bill for Montana or Idaho. Because designating roadless forest lands as wilderness removes them from multiple-use management, environmental groups view wilderness designation as the most effective means, within the existing legal framework, of preserving the ecological integrity of the Yellowstone region. They advocate setting aside large blocks of the current roadless lands as wilderness, emphasizing that additional wilderness would buffer existing park and wilderness areas and protect seasonal wildlife habitat and vital migration corridors. ${ }^{291}$ These lands, however, are also valuable for other purposes, and commercial inter-

Fed. Reg. 3325 (1989). To comply with the Conner v. Burford ruling, the regulations provide for use of a "contingent rights" stipulation (CRS) in all leases-a provision that would allow the Forest Service to preclude development of any lease if an unanticipated environmental contingency arose at any point after the lease was issued. Id. at 3326, 3329, 3333 (36 C.F.R. $\$ 228.103(\mathrm{c})$ (proposed)). The proposed regulations also vest the Forest Service with broad authority to modify lease stipulations, so long as the justification does not violate applicable laws, is consistent with the forest plan, and "is acceptable to the authorized Forest office based upon review of the environmental consequences of the proposed modifcation." Id. (36 C.F.R. $\$ 228.104$ (b) (proposed)). Although the Forest Service candidly admits that it probably would never use its CRS authority, the oil and gas industry strongly opposes the provision, viewing it as a dilution of the property interest that traditionally has attached to an oil and gas lease. Publ. LAND News, May 25, 1989, at 7. On the other hand, some environmentalists-apparently accurately - see the CRS stipulation as a device to avoid full-scale environmental analysis at the leasing stage, and not as an effective means of controlling development at later stages. Id.

290. See, e.g., Gallatin Forest Plan Feis, supra note 20, at 1-9; Draft Final BridgerTeton Forest Plan EIS, supra note 78, at 734-44; Sohare FEIS, supro note 279, at 187-203; Jackson Hole Guide, May 24, 1989, at Al (reporting that Jackson, Wyoming, businesspersons oppose oil and gas development in the national forests by a 2-1 margin). Significantly, on the Custer National Forest, Phillips Petroleum recently withdrew its drilling proposal for a well on pristine, high-elevation lands on the Line Creek Plateau just outside Yellowstone National Park, after facing substantial local opposition to the project. Denver Post, Aug. 7, 1988, at GI.

291. See Conservationists' Response to Senator John Melcher's S. 2790, at 71-76 (May 1987) (recommending, in particular, protection of the Gallatin Range); Gallatin Forest Plan Appeal, supra note 195, at 175. See also Map 2, supra page 940 . The 100th Congress passed a Montana wilderness bill entitled Montana Natural Resources Protection and Utilization Act of 1988, S. 2751, 100th Cong., 2d Sess. (1988), which designated wilderness lands in the Montana national forests, but the bill was pocket-vetoed by President Reagan just prior to the 1988 general election. See Luoma, Storming Montana's Wilderness, N.Y. Times, Apr. 16, 1989, $\$ 6$ (Magazine), at 34. 
ests as well as some recreational groups oppose most proposed wilderness additions.

The Forest Service is under a judicially imposed mandate to evaluate its roadless lands for wilderness potential, ${ }^{292}$ and it has just completed this process in its recent forest plans. There is little evidence, however, that the Forest Service has taken a regional, ecological perspective in making its wilderness recommendations. Throughout the region, it has recommended only modest additions of high alpine terrain to the wilderness system, choosing to keep most of its eligible lands, especially those situated at lower elevations where timber is more plentiful, available for multiple-use management. ${ }^{293}$ Both the Gallatin and Custer National Forests, for example, recommend substantially less than ten percent of their roadless acreage as wilderness. ${ }^{294}$ By limiting its wilderness recommendations, the Forest Service assures itself maximum flexibility in setting future priorities on the excluded lands, thus preserving intact its discretionary management authority. ${ }^{295}$

The dispute over the undeveloped lands in the southern portion of the Gallatin Range in the Gallatin National Forest of southwestern Montana illustrates the wilderness designation conundrum. Wilderness advocates note that the area provides important habitat for grizzlies, elk, and bighorn sheep that also utilize Yellowstone Park, and they argue that intensive development in the southern Gallatins would deter these species from using the area and further restrict their already limited range. ${ }^{296}$ Timber interests counter that the southern Gallatin Range has an abundance of mature timber that should be

292. California v. Block, 690 F.2d 753 (9th Cir. 1982). See generally Wilkinson \& Anderson, supra note 4 , at $345-52$.

293. Significantly, the NFMA regulations provide that forest managers, when evaluating the wilderness potential of their roadless lands, are to consider their proximity to other wilderness lands and potential changes in biological diversity. 36 C.F.R. $\$ 219.17$ (a)(1), (a)(2)(i)-(v). See also supra note 204 (regarding NEPA's biological diversity provision). Some forest plans have taken account of wilderness designations or recommendations on adjacent forests, thus coordinating wilderness recommendations among adjoining forests where management responsibility for large roadless tracts is shared. See, e.g., Gallatin Forest Plan FEIS, supra note 20, at II-32 to -33 (recommending 35,860 acres of wilderness on adjoining Targhee and Gallatin forest lands).

294. Gallatin Forest Plan Record of Decision, supra note 165, at 7, 17; U.S. Dep'T of Agric., Forest Service, Record of Decision, Custer National forest Management Plan iv, 20-21 (1986).

295. Management decisions reached in the forest plans can be changed later, but that is not the case once an area is designated as wilderness. Once the forest plan is finalized, however, it cannot be amended without complying with NEPA. 16 U.S.C. $\S 1604(f)(4) ; 36$ C.F.R. $\S 219.10(f)$.

296. See Conservationists' Response to Senator John Melcher's S. 2790, supra note 291, at 71-76. Wilderness designation also would protect stream quality, thereby benefitting the Yellowstone cutthroat trout, and it would limit access to the renowned Gallatin Petrified Forest. $I d$. at 72. See also Gallatin Forest Plan FEIS, supra note 20 , at C-17 to -42 . 
harvested or it will be lost to insect damage or fire. ${ }^{297}$ Some recreational interests oppose wilderness because it would deny access to an area that is popular for snowmobiling. ${ }^{298}$ In the forest plan, the Forest Service has sought to preserve its multiple-use options. It does not recommend wilderness designation; rather, it plans to permit limited timber harvesting, as well as motorized access during winter months. ${ }^{299}$ Moreover, the forest plan sanctions oil and gas leasing, leaving these lands open to mineral exploration and, potentially, development. $^{300}$ In short, the only definitive management commitment the agency has made is its nonwilderness recommendation.

Exactly how Congress finally will settle the wilderness question is still unclear, even though all sides are becoming increasingly anxious for a resolution. The final wilderness designation legislation will have a lasting impact on the natural character of the Greater Yellowstone region. ${ }^{301}$ But even a congressional resolution of the wilderness question will not end conflict in the region. If the Wyoming litigation over oil and gas leasing and timber production is any indication, conflicts like those involving the southern Gallatin Range simply will resurface elsewhere on "released" multiple-use lands. This fact quite plainly reinforces the pressing need for meaningful coordinated management taking account of the ecological importance of the region's remaining roadless lands.

\section{Interagency Coordination: The Quest for Common Ground}

\section{Keeping Agency Discretion Intact}

With public and private lands in the Greater Yellowstone region

297. Gallatin Forest Plan FEIS, supra note 20, at C-21, -22, -35, -36 .

298. Gallatin Forest PLAN FEIS, supra note 20, at III-22. For a brief summary of the public comments concerning wilderness recommendations, see id. at VI-7. See also CoNSERVATIONISTS' RESPONSE TO SENATOR JOHN MELChER's S. 2790, supra note 291, at 73-74.

299. Gallatin Forest Plan, supra note 163, at III-56 to -58; Gallatin Forest Plan RecORD OF DECISION, supra note 165, at 19. However, ignoring the Forest Service's recommendations, section 3(a)(18) of the Montana Natural Resources Protection and Utilization Act of 1988, supra note 291, would have provided wilderness protection for portions of the Gallatin Range.

300. Gallatin Forest Plan, supra note 163, at II-5, III-57. Currently there are lease applications outstanding for more than 34,000 acres in this area. GALLATIN FOREST PLAN FEIS, supra note 20, at C-23. Mineral activity is sanctioned under the forest plan, with provisions for location and timing restrictions. Gallatin Forest Plan, supra note 163, at III-57.

301. See supra text at notes 135-42. Ironically, while the Idaho wilderness bill introduced during the 100th Congress accepted most of the Forest Service's acreage recommendations, it attached numerous substantive restraints on the agency's management authority throughout the state's national forests. These provisions prompted the Forest Service to oppose the bill as an unwelcome intrusion into its management prerogatives and an unhealthy precedent. S. 2055, 100th Cong., 2d Sess. (1988). The bill was introduced by Senator James McClure and referred to the Committee on Energy and Natural Resources, but no further action occurred during the 100th Congress. See High Country News, Feb. 1, 1988 , at $1,12-13$, for a description of the bill. 
under separate federal, state, and local jurisdictional authorities, there is no common approach to land management. Moreover, there is no single entity empowered to assess the larger ecological ramifications of serial or concurrent development activities within the ecosystem. The federal agencies, however, have been addressing this coordination problem, at least on the federal domain. During the early 1960s Park Service and Forest Service officials created the Greater Yellowstone Coordinating Committee (GYCC) as a forum for discussing such matters as outfitter policies, fire management programs, and wildlife problems. ${ }^{302}$ Under the compulsion of the Endangered Species Act, ${ }^{303}$ the agencies also have created several interagency committees to coordinate recovery efforts for species such as the grizzly bear and bald eagle. $^{304}$ Most of the recent forest plans acknowledge that planning decisions should address regional impacts, ${ }^{305}$ though there is heated debate, as we have seen, over whether any real change has occurred in the Forest Service's priorities. Indeed, according to environmental groups, federal coordination efforts have not resulted in meaningful interagency cooperation sensitive to the cumulative, ecosystem-wide impacts of individual development proposals. On the other hand, industry groups and local development interests view the agencies' current regional coordination efforts with foreboding, concerned that cooperative management ultimately will mean that commodity uses will have to give way to protect noncommodity amenity values. ${ }^{306}$

In this highly visible, contentious atmosphere and with such nationally significant resources at stake, it is not surprising that Congress has become involved. Congress held an Oversight Hearing on the

302. AgGregation RePort, supra note 14, at vi. The Greater Yellowstone Coordinating Committee consists of the three regional foresters, the regional director of the Park Service, forest supervisors of six national forests, and superintendents of Yellowstone and Grand Teton parks. It is designed to improve communication among the agencies; it "does not impose decisions." Id. at vii. See also id. at 5-2 (Memorandum of Understanding between the regional offices of the National Park Service and the Forest Service, agreeing to cooperate and coordinate; the agreement can be terminated by any party on 30 days notice).

303. 16 U.S.C. $\$ \S 1531-1543$ (1982).

304. INTERAGENCY GRIzZly BEAR GuIDELINES, supra note 160, at 97 (Memorandum of Understanding between U.S. Dep't of Agriculture, U.S. Dep't of the Interior, Idaho, Montana, and Wyoming to revise and expand the Interagency Grizzly Bear Comm.); CRS EcosysTEM REPORT, supro note 14 , at 60 .

305. See Gallatin Forest Plan FEIS, supra note 20, at I-5, III-2; 1 Shoshone Forest Plan FEIS, supra note 163, at 6, 1-17; 2 Shoshone Forest PLAN FEIS, supro note 163, at VI-11 to -14.

306. During the 1986 session of the Wyoming legislature, a bill was introduced disavowing any state support for the concept of a Yellowstone ecosystem. Wyo. Digest of Senate \& House Journals, Budget Sess., 48th Legisl. 328-31 (1986). Although the bill was defeated, uneasiness about the consequences of recognizing the region as an ecosystem persists. See G. REYNolds, supra note 25; WyoMING'S FEDERAL LANDS, supra note 21. 
Greater Yellowstone Ecosystem in $1985^{307}$ and subsequently enlisted the Congressional Research Service (CRS) to prepare a report addressing the question of whether the overall Yellowstone management structure adequately assures coordination among the agencies. ${ }^{308}$ After examining extensive agency-submitted data, the CRS concluded: "The existing coordinating committees are not comprehensive in either membership or approach, and therefore are inadequate for providing complete, coordinated management of the Yellowstone ecosystem." 309 The report also noted that the agencies disagreed among themselves as to how often some of these committees meet, and that they were not sharing basic information on matters as central as grizzly bear population and mortality statistics. ${ }^{310}$ Moreover, the report concluded that the grizzly bear management zoning system has not protected the bear against illegal mortalities, and, labelling road construction the greatest single threat to the regional ecosystem, it found no evidence of an integrated road system planning effort. ${ }^{311}$ In sum, the Oversight Hearing and the CRS Report raised the very real specter that Congress might develop additional legislation to reform management practices in the Yellowstone region.

In the aftermath of the 1985 Oversight Hearing, to fend off the threat of congressional intervention, the Forest Service and the Park Service have intensified their coordination efforts. Under the aegis of a revitalized GYCC, the agencies have completed-as Phase One of an interagency coordination plan-an ecosystemwide Aggregation Report, which inventories resources on the public lands and details individual forest and park management plan provisions for matters such as fire control, oil and gas leasing, and wildlife management. ${ }^{312}$ In

307. According to Representative John Seiberling, Chairman of the House Subcommittee on Public Lands, the Oversight Hearing had three purposes:

First, to examine the meaning and significance of the Greater Yellowstone Ecosystem, its natural, cultural, and recreational resources, and their associated economic and environmental values; second, to identify the various resource uses, their relative benefits, and any potential conflicts among them; and, third, to review the strengths and weaknesses of the State and Federal arrangements now in place for managing the ecosystem and its resources."

Oversight Hearing, supra note 15, at 2.

308. CRS ECOSYSTEM REPORT, supre note 14 , at 35.

309. Id. at 179.

310. Id. at $143-46,178$.

311. Id. at 177.79 .

312. See Aggregation Report, supra note 14. The Report was prepared by the Greater Yellowstone Coordinating Committee, but it does not specify its origins other than to note that "concerns have been expressed by some segments of the public that ... management in the Greater Yellowstone Area is not coordinated." Id. at 1-1. The Report presents current information on natural resources, values, amenities, and economic and social conditions in the region, and makes projections about these matters in 10-15 years under the forest and park management plans. Where inconsistencies exist 
early 1988, the GYCC appointed a Regional Team Leader who is responsible for "coordinating the development of coordinated agency and interagency long-range goals, plans, and management strategies." 313 Now, during Phase Two of the coordination plan, the GYCC-acting through the Team Leader and utilizing the Aggregation Report information-is developing a "Vision for the Future" document that essentially will define management priorities in the Yellowstone region. ${ }^{314}$ After providing public involvement opportunities modeled upon those utilized in the NFMA forest planning process, ${ }^{315}$ the GYCC will adopt regional management goals, which each agency then will use as the basis for reexamining and revising planning documents and regional guidelines. ${ }^{316}$ Thus far, though, the GYCC has not made any substantive policy changes, ${ }^{317}$ and it remains to be

among the plans, the agencies will attempt to reconcile them and establish a more uniform management approach. Id. at vi, viii.

313. GM-101, 401, 801, 807, 1301-14 (Greater Yellowstone Area Team Leader), Position No. X2006111 (available from author). However, the Coordinating Committee, not the Team Leader, is responsible for all substantive policy decisions, and will ultimately decide whether policies are revised or standards modified.

314. Greater Yellowstone Coordinating Comm., Phase II-Applying the AggregaTION (1988) [hereinafter APPLYING THE AGGREGATION] (prepared by the GYCC Team Leader and staff); Greater Yellowstone Coordinating Comm., Public Participation Plan for the Greater Yellowstone Area Phase II-Plan Aggregation 1 (Mar. 1989) [hereinafter Public Participation Plan]. However, the GYCC emphasizes that this document "will not be a regional plan; it will not make specific land allocation decisions." APPLyING the AGgRegation, supra, at 2.

315. See Public Participation Plan, supra note 314, at 1-4. The GYCC public participation plan is "designed to involve the public as extensively as possible in the coordinated management decisions for the [Greater Yellowstone Area]." Id. at I. In brief, the GYCC will solicit public input, hold open forums, brief congressional staff, and encourage agency employee input in order to gather representative views on future management options for the Greater Yellowstone region. In several respects, this "process" mirrors the NEPA-driven NFMA forest planning process, which has involved open public meetings, public comment opportunities, and the like. However, the GYCC does not anticipate that NEPA compliance will be necessary until it begins revising management standards or plans. See AGGREGATION REPORT, supra note 14, at 4-2.

As designed, this coordination "process" itself could produce several salutary benefits. In a location where the Park Service and Forest Service historically have clashed with one another over land, it should allay lingering mistrust and suspicion about "turf" control and hidden agendas. The "process" also should provide all interested parties the opportunity to be heard and to participate in the decisionmaking process-a not inconsequential fact since the Park Service and Forest Service answer to quite different constituencies. And perhaps, as agency officials hope, the "process" will produce a degree of consensus among the opposing interests and legitimize the resulting policies. APPLYING THE AGGREgation, supra note 314, at 2; Public Participation PlaA, supra note 314, at 3.

316. Public Participation Plan, supra note 314; Aggregation Report, supra note 14, at 4 2.

317. However, the GYCC is proceeding, simultaneously with its development of the "Visions for the Future" document, to address regional management issues identified as particularly pressing. This is known as "Stage One" of Phase Two in the coordination process. AGgregation Report, supro note 14, at 4-2 (noting that the GYCC plans to address standard mineral leasing stipulations as a priority matter); APPLYING THE AGgREGATION, supra note 314, at 3-4. 
seen whether this elaborate "process" will result in meaningful ecosystem-based management. ${ }^{318}$

It is quite clear, however, that the Park Service and Forest Service adamantly oppose additional legislation. Agency officials are convinced that they have adequate authority to protect the environmental quality of the region and that interagency coordination efforts can succeed. ${ }^{319}$ Any legislation adopted by Congress, of course, would either impose additional substantive constraints on the land manager's discretionary authority or saddle him with additional procedural obligations. Yet, paradoxically, it has been the law, principally the Endangered Species Act, that has brought about one of the few substantive, regional management policies-the Interagency Grizzly Bear Management Guidelines-currently in place. ${ }^{320}$ Otherwise, "process" concerns have dominated interagency coordination efforts, and the resulting management decisions, as we have seen, can best be characterized as a series of ad hoc judgments. ${ }^{321}$ Thus, the crucial question is: Does the law provide any "teeth" for translating these interagency coordination efforts into substantive ecosystem management standards?

\section{A Substantive Coordination Requirement?}

The National Forest Management Act, 16 U.S.C. § 1604(a), imposes a clear legal obligation on the Forest Service to coordinate its land use planning process with its neighbors: "[T]he Secretary . . . shall develop, maintain, and, as appropriate, revise land and resource management plans ... coordinated with the land and resource management planning processes of State and local governments and other Federal agencies." 322 The Act does not further define what "coordination" means, but the legislative history reveals that Congress intended

318. Although the Greater Yellowstone land management agencies are reluctant to label their interagency management initiatives "ecosystem management," and even though the notion that the region constitutes an ecosystem remains anathema to some groups, the Park Service and Forest Service have committed to undertake "coordinated ecosystem management and protection" as part of a recent interagency memorandum of understanding signed by the Forest Service Chief and the National Park Service Director. Memorandum of Understanding Between the Forest Service and the National Park Service for Planning and Program Coordination 1 (Feb. 22, 1988) (available from author). Thus, the concept of ecosystem management has been endorsed at the highest level in each agency, and it is truly difficult to label these interagency coordination initiatives anything else. See also supra notes 24-25 and accompanying text.

319. Oversight Hearing, supra note 15, at 15-17 (statement of W.P. Mott, National Park Service Director); id. at 17-20 (statement of Robert Burford, BLM Director); id. at 53-57 (statement of Max Peterson, Forest Service Chief).

320. See supra notes $160-65$ and accompanying text.

321. See notes 341-44, 353-56 and accompanying text infra for a further discussion of the GYCC's interagency coordination processes.

322. 16 U.S.C. $\$ 1604$ (a) (1982). 
coordination to mean something more than mere notice and consultation. ${ }^{323}$ Not surprisingly, however, the Forest Service's implementing regulation treats the coordination provision largely as a "process" requirement. ${ }^{324}$ The regulation requires consultation with other agencies and governmental entities, but imposes no clear, affirmative obligation on the Forest Service to adjust its activities to accommodate neighboring land uses. The matter is left entirely within the discretionary authority of the forest supervisor. ${ }^{325}$

It is reasonable, however, to interpret the NFMA coordination responsibility as a substantive constraint on the Forest Service-one that requires forest officials to draft their plans to accommodate inconsistent adjacent land uses, especially when forest lands abut a national park or other "preserved" lands. This conclusion flows from the language, legislative history, and intent of the statute. It is a rudimentary principle of statutory construction that all language in the statute is to be given independent meaning, and that ambiguities are to be construed in light of the statutory purpose. ${ }^{326}$ In a separate provision the

323. The $\$ 1604(a)$ "coordination" requirement first appeared in the Forest and Rangeland Renewable Resources Planning Act of 1974 (RPA), 16 U.S.C. $\$ \S 1600-1614$, where it defined the Forest Service's planning responsibilities on individual forests. The provision subsequently was incorporated verbatim into the NFMA as part of the intensive forest planning mandated by that legislation. Signifcantly, the House-Senate Conference Committee on the RPA adopted the word "coordination" rather than the term "consultation" to describe the Forest Service's planning responsibilities vis-á-vis other federal agencies and state and local governments. H.R. CONF. REP. No. 1226, 93rd Cong., 2d Sess., reprinted in 1974 U.S. CODE CONG. \& ADMIN. NEws 4088, 4090. Congress did not intend the provision to be simply an exercise in "process" without substance; "coordination" has a substantive connotation, implying adjustment and realignment to harmonize adjacent uses. Moreover, the legislative history accompanying the NFMA does not address the $\$ 1604$ (a) coordination requirement. S. REP. No. 893, 94th Cong., 2d Sess. 40, reprinted in 1976 U.S. CODE CONG. \& ADMIN. NEws 6662, 6679, 6699. Rather, the NFMA legislative history addresses a provision requiring that the Secretary of Agriculture establish procedures for providing adequate notice and an opportunity to comment "on stan. dards, criteria and guidelines applicable to Forest Service programs"-an obvious reference to the Secretary's obligations under $\S 1612$ (a). Id. at 6699.

324. 36 C.F.R. $\$ 219.7$ (1988). Besides providing that "the line officer shall coordinate regional and forest planning with . . planning efforts of other Federal agencies," id. $\S 219.7$, the regulation requires forest planners to "review the planning and land use policies of other federal agencies," to assess "the interrelated impacts of these plans and policies," to determine how each Forest Service plan should deal with the impacts identified," and to consider alternatives for resolving conflicts. Id. $\$ 219.7(\mathrm{c})$. These requirements, however, simply duplicate the NEPA requirements that the Forest Service is obligated to follow in preparing its forest plans. See 40 C.F.R. $\$ \S 1502.16$ (c), 1506.2 (1988). See also 36 C.F.R. $\S 219.7$ (e) (imposing a monitoring and evaluation requirement on forest planners).

325. It is evident in the Yellowstone region forest plans that the Forest Service believes it has met this coordination obligation simply by advising its neighbors of the forest planning process, soliciting their comments, and then explaining its actions. See, e.g., Gallatin Forest PLAN FEIS, supra note 20, at VI-32 to -36; CUSTER Forest Plan FEIS, supra note 163, at 1-7 app. Particularly revealing of how short this falls of meaningful coordination is the Gallatin National Forest's failure even to respond directly to the concerns of Yellowstone Park officials over oil and gas leasing on the park's perimeters and its possible effect on the geyser system. GALLATIN FOREST PLAN FEIS, supra note 20, at VI-35.

326. Wilderness Society v. Morton, 479 F.2d 842, 856 (D.C. Cir. 1973) (en banc), cert. denied. 
NFMA otherwise assures "process" coordination with forest neighbors. ${ }^{327}$ Congress surely intended the section 1604(a) coordination provision to have some additional meaning beyond this. ${ }^{328}$ Moreover, giving section 1604(a) a substantive interpretation is fully consistent with the NFMA's primary objective-integrated, forestwide resource planning and management based upon sound environmental principles. $^{329}$ If forest supervisors are expected to manage their own forests according to these principles, then the coordination requirement must obligate them to adhere to these same principles when dealing with adjacent land owners.

This interpretation of the coordination requirement takes on added force when other federal laws place an adjacent land management agency under a legal obligation to protect its land and resources against degradation from external sources. As we have seen, this is precisely what the amended National Park Service Organic Act mandates in the case of the Park Service. ${ }^{330}$ In such circumstances, the logical way to harmonize otherwise conflicting congressional policies (i.e., multiple use and preservation) is to read the Forest Service's coordination requirement in conjunction with the Park Service's legal protection responsibility and to conclude that the coordination mandate obligates forest planners to minimize intensive development activities adjacent to parklands, at least where there is a demonstrably adverse environmental effect. This same conclusion follows in the case of the Forest Service's management of its own wilderness areas; as we

411 U.S. 917 (1973); West Virginia Div. of Izaak Walton League v. Butz, 522 F.2d 945, 948 (4th Cir. 1975).

327. 16 U.S.C. $\& 1612$ (1982) (providing for notice and comment opportunities for other federal agencies, state and local governments, and the public). See supra note 323 . See also 40 C.F.R. $\S \S 1502.16(\mathrm{c}), 1506.2$ (1988) (NEPA coordination obligations). Because these coordination requirements are already part of the Forest Service's obligations, an interpretation of the 16 U.S.C. $\$ 1604$ (a) coordination requirement that simply parallelled these requirements would effectively render $\$ 1604(a)$ redundant.

328. See supra note 323 and accompanying text. Cf. American Motorcycle Ass'n v. Watt, 534 F. Supp. 923 (C.D. Cal. 1981) (sustaining a claim against the BLM for failing to comply with the Federal Land Policy and Management Act coordination requirements, 43 U.S.C. $\$ 1712$ (c)(9) (1982), 43 C.F.R. $\S 1601.4$ (1988)), aff'd, 714 F. 2d 962 (9th Cir. 1983).

329. 16 U.S.C. $\$ 1604(\mathrm{~b}),(\mathrm{g})$ (1982). Throughout the legislative debates, principal sponsors of the NFMA invoked ecological principles when explaining the philosophy underlying their reform proposals. See generally Wilkinson \& Anderson, supra note 4, at 40-45, 69-75. Moreover, the Forest Service's implementing regulations endorse the principle of ecosystem planning - a concept that plausibly contemplates some restraint on development adjacent to pristine natural lands. 36 C.F.R. $\S 219.1(3)$ (1988).

330. 16 U.S.C. \$ 1a-1. See supra text at notes 97-101. See also 42 U.S.C. \$ 4332(c) (1982). Cf. Wilderness Society v. Tyrrel, 701 F. Supp. 1473, 1488-89 (E.D. Cal. 1988) (interpreting "cooperation" requirement in the Wild and Scenic Rivers Act, 16 U.S.C. $\$ 1283(\mathrm{c})$, as a limitation on the Forest Service's timber sales program); 40 C.F.R. $\$ 1501.6$ (1988) (requiring agencies complying with NEPA to consult with sister agencies possessing special expertise). 
have seen, it operates under a similar legal protection responsibility when managing its wilderness lands. ${ }^{331}$ Harmonizing these statutes in this manner is consistent with the environmental protection philosophy evident throughout the NFMA.

In the Greater Yellowstone region, unless the NFMA coordination requirement is given some substantive content, interagency coordination will remain a largely voluntary undertaking, and individual land managers will continue to enjoy virtually unconstrained authority within their own domains, even when their decisions may negatively impact adjacent lands or shared resources. Voluntary undertakings like the Aggregation Report do not obligate the agencies to any subsequent course of action, and such efforts have not "cost" the agencies anything - no projects have been foregone, no additional management obligations have been incurred. Indeed, if the NFMA coordination requirement continues to be interpreted merely as a "process" obligation, the provision will be trivialized with the critical issue simply being whether forest officials consulted with their neighbors. As Congress already has learned, this does not provide meaningful protection for the ecosystem, nor does it assure that regional concerns are integrated into multiple-use management practices.

\section{Ecosystem Management: Perspectives From the Law}

The Greater Yellowstone public lands no longer can be viewed as discrete and separate entities, each managed without regard for neighbors or shared resource systems. Acting through the Greater Yellowstone Coordinating Committee, the federal land management agencies have acknowledged the interconnectedness of the region, and they have created a "process" for addressing the future and striking a new balance sensitive to ecological imperatives as well as individual human interests. Current law, while not pushed nearly to its potential limits, has clearly influenced this development; it not only legitimizes the emerging notion of ecosystem-based management, but it also provides agency officials with sufficient authority to implement ecologically sound policies. Yet within the Forest Service and Park Service, traditional boundary-based conceptions of public lands policy are still evident and could impede efforts at translating the concept of ecosystem management into meaningful, binding transboundary resource management policies and standards - the real key to preserving Greater Yellowstone intact.

331. See supra text accompanying notes $125-34$. 


\section{A. De Facto Regionalism: Surmounting the Tradition of Discretion}

Ecosystem-based management is the next logical phase in the historical evolution of public lands policy. At the national level, new amenity values rooted in the preservationist tradition have ineluctably displaced older utilitarian traditions in defining natural resource management priorities. ${ }^{332}$ Modern environmental laws, reflecting advanced scientific knowledge about the workings of natural systems, now impose significant constraints on consumptive-use activities on the public lands. A new order is displacing traditional conceptions about the relationship between man and the natural environment. ${ }^{333}$ The transition, however, is not coming easily on the public domain throughout the West. Even in regions like Greater Yellowstone, which boasts a strong preservationist heritage and a powerful national constituency, local economic interests committed to the utilitarian tradition and long accustomed to unbridled access to public resources have resisted even modest changes in management philosophy. Nonetheless, the future of the Greater Yellowstone region is being set by these federal laws, and the fundamentals of management policy ultimately will be defined by reference to national rather than local values.

Fittingly, the Park Service and Forest Service are the federal agencies now undertaking the precedent-setting task of bringing this transition to fruition on the public domain, with the Greater Yellowstone region serving as a testing ground..$^{334}$ Both agencies have a lengthy history of accomplishment in the field of natural resources management, and they share a common tradition of wildland preservation. Despite divergent mandates and quite different constituencies, the Forest Service's broad multiple-use mandate authorizes the agency to implement amenity-based resource management policies closely paralleling those followed by the Park Service. ${ }^{335}$ In addition, both agencies have integrated science-based resource management princi-

332. See, e.g., P. LIMERICK, supra note 40, at 293-321; Wilkinson, supra note 39. See also supra text at notes 4-6.

333. See generally R. NASH, The Rights of NATURE: A History Of ENVIronmental Ethics (1989); S. Hays, supra note 5; D. Worster, NATURE's Economy: ThE ROOTS Of Ecology (1977).

334. A dialogue about ecosystem management in the abstract already has begun between the Park Service and the Forest Service. During spring 1987 at the University of Washington, the Park Service sponsored a workshop, which involved Park Service and Forest Service representatives as well as various academics, entitled "Ecosystem Management for Parks and Wilderness." See Ecosystem MaNagement for Parks and WILderness, supra note 24. Cf. U.S. Parks Try to Control Outside Forces, The Denver Post, Mar. 28, 1989, at 6A, col. 1 (noting that Glacier National Park has hired the National Park Service's first "ecosystem manager").

335. See supra notes 209-16, 240-44 and accompanying text. See also notes 130-34 and accompanying text and note 273 . 
ples into their governing philosophies. ${ }^{336}$ Neither agency, however, has yet shaken itself entirely free from long established institutional traditions-namely a preoccupation with the boundary line and a dogged commitment to the principle of managerial discretion-that will hinder the search for regional solutions.

Moreover, the Yellowstone region land management agencies are not entirely in control of matters. Congress already has passed legislation limiting geothermal development outside the parks ${ }^{337}$ and addressing oil and gas activity on the public lands. ${ }^{338}$ Congress also will have the final word on the wilderness question and, perhaps, in the wolf reintroduction debate. Furthermore, in the wake of the 1985 Oversight Hearing, Congress holds something of a Sword of Damocles over the entire Yellowstone region; the threat of comprehensive legislation is still palpable. ${ }^{339}$ The courts, too, have shown a willingness to intervene in land management controversies and to order Forest Service managers to reexamine their priorities. Although the courts have not displaced the land managers' authority to establish basic policy, even the ESA and NEPA procedural rulings send a strong message to officials that their discretion on the roadless forest lands is not unbounded. ${ }^{340}$

The Park Service and Forest Service have not missed the basic point: The ascendant administrative policy direction plainly is toward regionalism. Indeed, the administrative actions of the Greater Yellowstone federal land management agencies have given de facto recognition to the region, or ecosystem, as the relevant management unit. National forest and national park lands have been linked together as an ecological entity. Interagency management initiatives, such as the GYCC's regionwide Aggregation Report, the Team Leader position,

336. In the case of the Forest Service, this scientific tradition has been part of the agency since its earliest days, and the NFMA further institutionalizes a role for science in forest management policy. $S$. Hays, Conservation and The Gospel of efficiency: The Progressive Conservation MOVEMENT, 1890-1920, at 27-48 (1959). See also supra text at notes at 84-85, 216 . In the case of the Park Service, a preoccupation with scientific management has come somewhat later, but the agency is now basing its natural process management philosophy on scientific data. A. RUNTE, supra note 7, at 197-208. But see A. CHASE, supra note 29, at 232-61 (asserting that the Park Service science program is deficient and seriously underfunded). See generally J. Clarke \& D. McCool, Staking Out the Terrain: Power Differentials among Natural Resource Management agencies (1985).

337. 30 U.S.C. $\S 1005$ (Supp. V 1987).

338. See supra notes $253,273,286-87$ and accompanying text. It remains to be seen whether Congress-once it receives the National Academy of Sciences's and the Comptroller General's report on oil and gas leasing under the NFMA and FLPMA planning processes-will be persuaded to enact further legislation imposing environmental review standards on the Forest Service and the BLM as part of its reform of onshore oil and gas leasing practices. See supra note 287 and accompanying text.

339. See supra notes 307.18 and accompanying text. Moreover, generic park protection legislation surfaces regularly on Congress's agenda. See supra text at note 12.

340. See, e.g., supro notes 79-80, 170-73, 221-27, 261-68, 279 and accompanying text. 
and the Phase Two process, ${ }^{341}$ as well as the endangered species recovery committees, ${ }^{342}$ manifestly are designed to address regional concerns and, ultimately, to formulate regional management policies for the federal domain. Whether these initiatives can be traced to existing statutory mandates, sustained public pressure, or the threat of congressional intervention, the important fact is that a structure and "process" for moving ahead with regional management are in place.

But are the Park Service and Forest Service, acting jointly through the GYCC, institutionally capable of articulating and implementing a functional, ecosystem-based management policy? As agency officials know in the aftermath of the highly critical CRS report, ${ }^{343}$ an effective ecosystem management strategy must be built upon something more than "process," especially in a setting as visible, diverse and volatile as the Greater Yellowstone region. Agee and Johnson, describing ecosystem management, make the point this way: "Interagency coordination is often a key element of successful ecosystem management, but is not an end itself. Success in ecosystem management is ultimately measured by the goals achieved, not by the amount of coordination." 344 In short, effective coordinated regional management depends upon the definition and implementation of ecosystem-based policies and standards.

Despite the current rhetoric of regional coordination, the evidence suggests that Forest Service and Park Service officials are still constrained by their engrained institutional commitment to boundarybased management and the principle of managerial discretion. In the case of the Forest Service, although the recent forest plans acknowledge a responsibility to the region, agency officials have foreclosed few of their multiple-use options. Despite continuing concern among park officials over oil and gas activity on their borders and its potential impact on wildlife habitat and geothermal systems, only the Bridger-Teton forest has even considered a mineral leasing buffer zone on forest lands along park perimeters, and it has now abandoned that proposal. ${ }^{345}$ And the Forest Service's wilderness recommendations in Idaho and Montana-rather paltry for a region known internationally for its natural values-would infringe only minimally on its managerial pre-

341. See supra notes 312-17 and accompanying text; infra notes 353-56.

342. See supra notes $160-61,304$ and accompanying text.

343. See supra notes 308-11 and accompanying text.

344. J. Agee \& D. Johnson, Ecosystem Management for Parks and Wilderness: WORKSHOP SYNTHESIS 6 (Inst. of Forest Resources, Contrib. No. 62, 1988). See also T. Clark \& A. Harvey, Management of The Greater Yellowstone Ecosystem: an Annotated BibliogRAPHY 19-21 (1988).

345. See supra note 112 and accompanying text. 
rogatives on the roadless forest lands. ${ }^{346}$ As for the Park Service, Yellowstone officials-bowing to sustained local political pressure and ignoring an earlier commitment to recover grizzly habitat and to enhance park natural values-have relied upon their discretionary authority and decided to retain the controversial Fishing Bridge campground. ${ }^{347}$ Predictably, these same pressures again confront Park Service officials as they formulate a winter-use plan to address the burgeoning demand for developed and motorized winter recreational opportunities within the parks. ${ }^{348}$

These as well as other important policy decisions, as agency officials acknowledge, are each loaded with regional, and even national, implications. Yet the decisions reflect what can best be described as a series of ad hoc judgments, often compromising significant natural values to maintain managerial flexibility or to accomodate local interests. Lacking any principled basis for evaluating the regional implications of these matters, the agencies inevitably have tempered ecological concerns with judgments about political convenience and local economic impact. ${ }^{349}$ The environmental costs of this approach are apparent: Little or no regard has been given to the cumulative, regionwide impact of development proposals, which has meant the piecemeal fragmentation of important wildlife habitat as well as the erosion of the wilderness-like character of the region. ${ }^{350}$ But there are other costs as well, principally the lack of stability and predictability that are the bedrock of rational resource planning for local communities and businesses. Moreover, this commitment to managerial discretion opens the agencies to the very political pressures that are likely to continue frustrating their quest for enduring ecosystem management principles. Perhaps this is why, as we have seen, virtually none of the major con-

346. See supra notes $293-300$ and accompanying text.

347. See supra notes 82,87 and accompanying text.

348. See supra note 96 and accompanying text.

349. This disjointed approach to management policy is reflected in the fact that the Shoshone and Custer forests have placed their critical grizzly bear lands off-limits to oil and gas leasing, yet other forests have opened critical habitat lands to leasing. See supra notes 112, 163, 230, 234, 280-81. And while the Bridger-Teton and Shoshone forests have reduced their timber sale projections, the recent forest plans show other forests escalating their annual harvests. See supra notes 229, 235. Perhaps the most telling example of this involves the Fish and Wildlife Service. Bowing to perceived local opposition, the FWS has failed to delineate critical habitat for the grizzly bear under the ESA; instead, it relies upon a management zoning scheme--a scheme that the Congressional Research Service found inadequate to insure the bear's survival. See supra notes 161, 308-11 and accompanying text.

350. See supra notes 73-78 and accompanying text. Of course, the CEM model, which has been developed under the ESA, seeks to address this problem in the case of the grizzly bear, but the model focuses solely on grizzly bear habitat. There is no comparable aggregate, regionwide measuring device for other important ecosystem components. 
troversies involving either forest or park lands has yet been finally resolved.

This reluctance to forego discretionary managerial authority is institutionally pervasive throughout the agencies. Recent NFMA appeal decisions reveal that the Forest Service, at its highest levels, is loath to relinquish any of its managerial discretion. These decisions uniformly have held that final resource allocation decisions are not being made in the forest plans but will be made later, leaving land managers free to reassess and change forest plan determinations. ${ }^{351}$ This same approach is reflected in the Forest Service's recently proposed oil and gas regulations, which would vest local officials with the authority to revise leasing decisions and stipulations. ${ }^{352}$ Similarly, neither the Forest Service nor the Park Service has yet taken any steps, other than a memorandum of understanding, to confirm either the GYCC's structure or its Phase Two "process" by legally binding regulations; ${ }^{353}$ the Coordinating Committee as well as its initiatives could be abandoned next month, by either agency, without legal sanction. ${ }^{354}$ And despite the message Congress has sent with its recent oil and gas leasing and geothermal legislation, the GYCC, at least thus far, has not promulgated any standards governing even pressing transboundary resource management problems. ${ }^{355}$

The problem is not that flexibility is inherently bad. Times change and society's values are constantly evolving. Once-dormant natural resource needs can become pressing demands, as occurred in the case of petroleum in the aftermath of the Arab oil embargo. Nor is the GYCC's "process"-based approach to regionalism necessarily faulty or destined to fail. ${ }^{356}$ Serious interagency coordination efforts

351. See supra note 218 and accompanying text.

352. See supra note 289 and accompanying text.

353. See supra notes $302,312-18$ and accompanying text. It should be noted that the GYCC itself has no formal rulemaking authority; however, the Aggregation Report contemplates that each agency will be integrating the Coordinating Committee's recommendations into regional guides and management plans. AgGregation Report, supra note 14, at 4-2. The binding legal effect of the Forest Service's regional guides and other planning documents is unclear in the aftermath of the agency's NFMA administrative appeal decisions. See supra note 218 and accompanying text. See also National Wildlife Fed'n v. Costin, 773 F.2d 1513 (9th Cir. 1985).

354. Indeed, the Phase Two "process" is designed to terminate upon completion of the "Visions for the Future" document and identification of park and forest plan inconsistencies. From this point forward the individual agencies will be responsible for implementing and monitoring the GYCC recommendations, and the Team Leader position apparently will be abolished. AGGrEGATION RePORT, supra note 14, at 4-2. See also APPLYING THE AGgregation, supra note 314, at 1-6.

355. See supro notes 312-18 and accompanying text.

356. However, the GYCC, which is now composed exclusively of federal agency representatives from the Park Service and Forest Service, ultimately may prove insufficiently representative of the multifarious interests concerned with future management options in the Yellowstone region to assure the legitimacy and broad acceptance of its decisions. The U.S. Fish \& Wildlife Service and perhaps the 
have just begun in the last couple years, and the GYCC is staking out new terrain in an area where interagency rivalries are legendary. Caution surely is warranted in the volatile Greater Yellowstone environment where traditional adversaries have proven themselves prepared both to litigate and lobby to advance their agendas. But without a joint commitment based upon clearly defined priorities and binding standards, flexibility can-as it has in the past-become a guise for politically expedient, rather than principled, ecologically sound decisions.

\section{B. An Emerging "Common Law" of Ecosystem Management}

Is there sufficient legal authority for the land managers to reorder their priorities to take full account of the ecosystem? The burden of this article, in large measure, has been to provide an affirmative answer to this question. As we have seen, existing legal mandates-in a piecemeal and perhaps still incomplete manner-protect specific ecological components and endorse ecosystem preservation as a fundamental tenet of federal public lands policy. Moreover, the courts consistently have confirmed the authority of land managers to make and implement resource management decisions giving priority to environmental values, so long as they have fulfilled their procedural obligations. Thus, rather than perceiving the law as a constraint, the agencies can and should view the law as an ally in their efforts to implement what amounts to an emerging "common law" of ecosystem management.

Viewed in total, the law reflects an impressive, judicially enforceable congressional commitment to ecologically sound public land management. The Endangered Species Act, perhaps the most powerful substantive law governing public lands policy, sets a clear priority for

BLM are key federal participants in regional affairs, and the surrounding states, not to mention many of the local communities and interest groups, have strong intersts in federal management policies. See $\mathrm{T}$. Clark \& A. HARVEY, supra note 344, at 21 . Should the current approach falter, several models of intergovernmental regional planning and management bodies already exist from which the GYCC might draw in restructuring itself to reflect a broader array of interests and to facilitate decision making. See, e.g., 16 U.S.C. $\$ 839 \mathrm{~b}$ (1982) (establishing Pacific Northwest Electric Power and Conservation Planning Council); Mont. Code Ann. $\$ \S 75-7-301$ to -308 (1987) (creating a Flathead Basin Commission); 16 U.S.C. $\$ 471$ (1982) (establishing a Pinelands National Reserve planning entity). See also Good \& Good, The Pinelands National Reserve: An Ecosystem Approach to Management, BioScl., Mar. 1984, at 169 (explaining management of the New Jersey Pine Barrens National Reserve); Wilkinson \& Conner, The Law of the Pacific Salmon Fishery: Conservation and Allocation of a Transboundary Common Property Resource, 32 Kansas L. REv. 17, 94-107 (1983). On the other hand, consolidation of the three Forest Service regions represented in Greater Yellowstone into one regional office representing only the Yellowstone area forests would facilitate the GYCC's coordination efforts. The fact that this has not occurred may be a further reflection of the Forest Service's general resistance to institutional change. 
species preservation and is not boundary-limited. ${ }^{357}$ The rather technical and somewhat qualified NFMA also contains substantive standards designed to insure the ecological integrity of the national forests; ${ }^{358}$ its biological diversity requirements are serving as a meaningful restraint on environmentally harmful logging activity in the $\mathrm{Pa}$ cific Northwest. ${ }^{359}$ Although NEPA is a procedural statute, it is designed to insure that ecological factors, including transboundary impacts, are identified and considered before federal land management agencies authorize development proposals that disturb the natural environment. ${ }^{360}$ The protection provisions in the organic park and wilderness laws are not only intended to protect these preserved lands against impairment from outside sources, but they legitimize interjurisdictional management arrangements. ${ }^{361}$ Moreover, when these protection requirements are interpreted in conjunction with the NFMA section 1604(a) coordination requirement, the concept of interagency coordination takes on substantive content and compels restraint as a guiding management principle on multiple-use lands adjacent to national parks and wilderness areas. ${ }^{362}$

The Yellowstone region judicial decisions likewise support the conclusion that agency officials have the inherent legal authority to develop and implement ecosystem-based management policies. First, the decisions affirm the principle of managerial discretion and thus vest the land manager with rather broad authority over his domain. ${ }^{363}$. Second, despite recurrent litigation seeking judicial endorsement of a dominant-use agenda, the courts have not endorsed the proposition that commodity production should take precedence over other uses of the national forests. ${ }^{364}$ In the case of the Bridger-Teton's Dubois-area timber harvesting policies, for example, the court found no legal basis for questioning the Forest Service's policy judgment giving priority to the wildlife resource on these multiple-use lands. ${ }^{365}$ Third, on several

\footnotetext{
357. See generally supro section IV.B.1.

358. See supra notes $187-98,203$ and accompanying text.

359. See supra notes 199-202 and accompanying text.

360. See supra notes $80,118,131-34,204,220-27$ and accompanying text.

361. See supra notes 97-101, 125-29 and accompanying text and text following notes 112, 142.

362. See supra notes 326-31 and accompanying and following text.

363. See, e.g., National Wildlife Fed'n v. National Park Serv., 669 F. Supp. 384 (D. Wyo. 1987); Intermountain Forest Indus. Ass'n v. Lyng, 683 F. Supp. 1330 (D. Wyo. 1988).

364. See, e.g., Intermountain Forest Indus. Ass'n v. Lyng, 683 F. Supp. 1330 (D. Wyo. 1988); Sierra Club v. Peterson, 717 F.2d 1409 (D.C. Cir. 1983). There is one possible exception to this conclusion, namely, the oil and gas leasing withdrawal decisions in Wyoming involving the Bridger-Teton National Forest. Mountain States Legal Found. v. Andrus, 499 F. Supp. 383 (D. Wyo. 1980); Mountain States Legal Found. v. Hodel, 668 F. Supp. 1466 (D. Wyo. 1987). But see supna text at notes 277.
} 78.

365. Intermountain Forest Indus. Ass'n v. Lyng, 683 F. Supp. 1330 (D. Wyo. 1988). 
occasions the courts have intervened to protect, at least temporarily, environmental values or the roadless character of forest lands. For example, in the oil and gas leasing cases, the judicially imposed NEPA injunctions have had the effect of compelling Forest Service officials to broaden their environmental analyses, obligating them to review the temporal and spatial ecological impacts of their decisions. ${ }^{366}$ Thus, the decisions, viewed collectively, establish the general proposition that management decisions giving priority to natural values are consistent with existing statutory mandates and can withstand judicial scrutiny.

Indeed, the land management agencies have begun developing, through administrative initiatives, the rudiments of a "common law" of ecosystem management. Under the ESA, the agencies have developed the ecosystem-based grizzly bear management zoning system, which effectively establishes substantive standards governing land management practices on park and forest lands to insure the bear's habitat. ${ }^{367}$ Should wolf reintroduction occur, it too will be managed through a similar interjurisdictional zoning scheme. ${ }^{368}$ The administratively conceived "natural burn" fire policy, which is derived from the preservation mandates in the organic park and wilderness legislation, also represents a substantive interagency management policy implemented through a zoning system that gives primacy to natural processes on park and wilderness lands. ${ }^{369}$ On a smaller scale, the Bridger-Teton's decision to include a cumulative effects, full-field development environmental analysis of potential oil and gas activity in its final forest plan-despite the Park County decision that seemingly relieved forest officials of this obligation-reflects a heightened sensitivity to the regional implications of such development activity. ${ }^{370}$ Thus, though still fragmentary and incomplete, the initial outlines of an administratively constructed ecosystem management policy are apparent.

Disturbingly, however, most of these manifestations of an emerging "common law" of ecosystem management stem from powerful

366. See, e.g., Sierra Club v. Peterson, 717 F.2d 1409 (D.C. Cir. 1983); Conner v. Burford, 848 F.2d 1441 (9th Cir. 1988), cert. denied sub nom., Sun Exploration \& Prod. Co. v. Lujan, 109 S. Ct. 1121 (1989); California v. Block, 690 F.2d 753 (9th Cir. 1982).

367. See supra notes 161.62 and accompanying text.

368. See supra note 175 .

369. See supra notes 89.90 and accompanying text.

370. See supra text at notes 279-81. Another forestwide example of an ecologically sensitive zoning scheme is the Bridger-Teton's decision, in its final forest plan, to impose NSO stipulations on mineral leases affecting $\mathbf{9 7 5 , 0 0 0}$ acres of steep-slope forest lands, a decision that is predicated upon the NFMA soil stability provisions and that may set leasing standards for the other regional forests. See supra notes 230, 255. But see infra text at note 374 . 
substantive laws such as the ESA, or from NEPA, which has received vigorous judicial enforcement. Or, as in the case of the "natural burn" fire management policy, the policy can be traced to unambiguous, single-use laws such as the Wilderness Act. Can-or will-the agencies invest the inherently weaker protection and coordination mandates with similar meaning by developing substantive, ecosystem-based management standards dealing with adjacent lands and ecologically sensitive areas? $?^{371}$ Of course, such a step, by its very nature, would impose constraints on traditional consumptive-use activities and thus test the Forest Service's commitment to a régional management agenda. The fact that even the ESA has been diluted in the Greater Yellowstone region to accomodate powerful, local political interests counsels caution in forecasting a new era in public land management. ${ }^{372}$

The principle of discretionary management authority is a twoedged sword. Discretionary authority can be utilized not only to implement ecosystem-based management policies, but it also can be relied upon to countenance intensive development activity on ecologically sensitive lands. Indeed, as we have noted, agency policies and decisions-as reflected in the Park Service's Fishing Bridge decision and the Forest Service's oil and gas leasing program in Wyoming-have vacillated in just this manner. ${ }^{373}$ Moreover, administrative discretion can be relied upon to avoid institutionalizing legally binding commitments. Policies like the Bridger-Teton's forest plan solution to the oil and gas development dilemma-the use of NSO stipulations on steep slopes-probably lack any meaningful legal force; such decisions apparently are not binding and the stipulations routinely have been waived. ${ }^{374} \mathrm{Can}-$ or will-the agencies, therefore, take the further step of confirming such policies in legally binding administrative regulations or as legally binding regionwide policies? ${ }^{375}$

Should the agencies default by failing to develop comprehensive and functional ecosystem-based management policies, the current re-

371. See supra note 112 (noting that the Bridger-Teton National Forest recently dropped plans to establish a mineral leasing buffer zone adjacent to Grand Teton National Park).

372. See supra note 161 .

373. Notably, both of these decisions have withstood judicial challenges. See supra notes 87,263 65,285 and accompanying text.

374. See supra notes 218,283 and accompanying text.

375. Paradoxically, if agency officials utilize their discretionary power to establish legally binding ecosystem management standards, they might insulate themselves from legislative incursions or judicially-imposed mandates, and thus preserve a measure of administrative autonomy. For example, the grizzly bear zoning scheme has enabled the Park Service to withstand judicial challenge in the Fishing Bridge case, and the substantive natural fire policy has apparently withstood modification by Congress. See supro notes $87,89-94,166-67$ and accompanying text. 
gionalism initiatives-which effectively legitimize the ecosystem as the appropriate management entity-could alter the status quo in the courts and Congress. De facto recognition of the ecosystem by the land managers may embolden the courts to enforce the extraterritorial protection responsibilities found in the organic park and wilderness legislation. ${ }^{376}$ It also could lead the courts to read substantive obligations into the NFMA coordination requirement, effectively establishing binding standards governing management decisions on public lands adjacent to preserved lands. ${ }^{377}$ Furthermore, de facto recognition of the ecosystem could change the political calculus before Congress in such intense conflicts as the issue of wilderness designation and oil and gas exploration on largely undisturbed lands. Even more importantly, administrative treatment of the Greater Yellowstone region as the relevant management entity presents Congress with impressive evidence that a regional legislative solution is the only viable means of bringing these persistent resource conflicts under control.

\section{In Search of Guiding Principles}

The true test of an administratively constructed ecosystem management scheme is the formulation of comprehensive transboundary resource management policies predicated upon sound ecological principles and the confirmation of substantive governing standards through legally binding commitments. The GYCC now has in place a sophisticated "process" for constructing just such a management scheme, assuming agency officials can overcome their own institutional traditions and not-inconsiderable local resistance. As an initial matter, the challenge confronting the Greater Yellowstone land management agencies is-to paraphrase Aldo Leopold's words-to articulate an ecosystem or regional ethic that sets the framework for future management of the region's public lands. ${ }^{378}$ This is a normative, value-based determination that will involve ordering into a set of governing priorities the disparate environmental, economic, political, aesthetic, cultural, and other values attached to the region's national park and forest lands. ${ }^{379} \mathrm{Next}$, the challenge is to translate the identified

376. See supra notes $97-101,123-29$ and accompanying text.

377. See supra section IV.D.2.

378. See supra text at note 10. This is not to suggest that either the Park Service or Forest Service should be rewriting their basic organic mandates; rather, this simply recognizes the inherent elasticity in a management standard such as the multiple-use concept, which clearly can accommodate management policies giving primacy to amenity values. See, e.g., supra notes 240-44 and accompanying text.

379. See, e.g., J. SAX, supro note 41, at 103-109; S. DANA \& S. FAIRFAX, supra note 1, at 321-46; Wilkinson, supra note 39 , at $401,404-10$. In a sense, this is what the GYCC Phase Two process is designed to do with development of the "Vision for the Future" document, which, as the agencies have recognized, will reflect value-based judgments about appropriate regional goals. APPLYING THE AG. 
priorities into a set of compatible resource management principles and governing standards. ${ }^{380}$ This process of implementing ecosystembased resource management principles necessarily will draw heavily upon science. Moreover, one overarching concern is that the resulting management scheme must provide sustainable local economic opportunities.

While any threshold, value-based determinations about Greater Yellowstone's future must account for the inherent tension between national and local land use preferences, the prominence of Yellowstone insures that national values will (and should) be given primacy on the regional management agenda. Agency officials, therefore, should acknowledge explicitly, as a regional ethic, a primary commitment to maintain the natural values and thus the ecological integrity of the region. ${ }^{381}$ This would insure protection for the myriad wildlife resources and natural features, as well as the wilderness-like setting, that account for Greater Yellowstone's uniqueness and international stature as the preeminent example of this nation's preservationist legacy.

Such a commitment to naturalness rather accurately manifests existing federal legislative priorities and administrative policies, as well as local economic realities. In a very real sense, Congress already has recognized naturalness as a national priority in the Greater Yellowstone region. Besides the two world-renowned national parks and three wildlife refuges, Congress has preserved nearly fifty percent of the region's national forests as wilderness, and it will add to this when it completes the wilderness designation process for Montana and Idaho. The fact that Congress apparently is not prepared to rewrite the "natural burn" policy reflects this commitment to naturalness, as well as the evolution of natural resources management policy from a narrow, human-oriented focus to a recognition that ecological processes are important dimensions of public land management policy. ${ }^{382}$ And of course, as we have seen, current federal law validates

GREGATION, supra note 314, at 2. Cf. 36 C.F.R. $\$ 219.3$ (1988) (recognizing that "net public benefits" in the forest planning process include qualitative criteria).

380. See supra notes 314-16 and accompanying text (explaining that the GYCC Phase Two process will result in identified goals being used to determine needed revisions to management guides and plans).

381. As used, the term "natural values" should not be read to suggest a management standard of "naturalness" for the Greater Yellowstone region. See J. AGEE \& D. JoHNSON, supra note 344, at 6. Rather the term is used to identify an overarching value or goal-in terms that are widely understood and supported by the public-toward which management policies should be geared. Once such a valuebased commitment is made, then it is incumbent upon land managers to define management standards, drawing upon contemporary scientific principles and the like, that will insure the region's basic ecological integrity while also meeting human needs. See infra text at notes 385-92.

382. Another telling recognition of this fundamental reorientation in public land management 
the principle of ecosystem management on the public domain. In addition, the land management agencies-with their current regionalism initiatives and their role in the emerging "common law" of ecosystem management-already have established something of a de facto priority for sustaining ecological processes in the Greater Yellowstone region. ${ }^{383}$

Although the science of ecology-which demonstrates the links connecting Yellowstone area public lands-provides the predicate for regionalism, science itself cannot define a new ethic (or management priorities) in an area like Greater Yellowstone. Science attaches no significance or value to the many human interests that figure prominently in policy judgments about the public lands. ${ }^{384}$ Nevertheless, science will play an important role in implementing the concept of ecosystem-based management in Greater Yellowstone and elsewhere on the public domain. Indeed, a primary goal of preserving natural ecological processes can be implemented only by relying upon scientific criteria. ${ }^{385}$ Not only does science provide objective criteria for establishing the necessary management standards, but scientific research provides the basis for measuring whether management goals have been met. The agencies, which are governed by numerous science-based legal standards, already are familiar with a management regime predicated upon scientific precepts. ${ }^{386}$ Moreover, the quantita-

philosophy would be a decision-either congressional or administrative-to proceed with wolf reintroduction in the Yellowstone region. See supra text at notes 174-82.

383. Indeed, given the fragmented jurisdictional boundaries, various legal mandates, and diverse human interests in Greater Yellowstone, the only reasonable explanation for these administrative initia. tives is a shared commitment to insure the ecological integrity of the region. See AGgregation REPORT, supra note 14 , at $4-1$.

384. For example, aesthetic considerations-undoubtedly the raison d'etre for the national parks-have no apparent place in a purely scientific conception of public land management. Nor do the principles of ecology alone provide an acceptable answer to such questions as the appropriateness of oil and gas drilling on roadless forest lands lying in the shadow of the Grand Tetons. In fact, however, aesthetic considerations have become an important, accepted dimension of multiple-use management. See, e.g. 16 U.S.C. $\S 1604(\mathrm{~g})(3)(\mathrm{F})(\mathrm{iii}),(\mathrm{v})(1982)$ (providing that clearcuts in the national forests must be shaped to be consistent with aesthetic resources); 43 U.S.C. $§ 1702$ (c) (1982) (defining "multiple use" for purposes of FLPMA to include aesthetic values on the public lands). See also A. RUNTE, supra note 7, at 11-47; W. HammitT \& D. Cole, WILdLANd ReCreation: Ecology and MANAGEMENT 16-17 (1987) (comparing the ecologist's and recreationist's perceptions of backcountry natural resource disturbance).

385. J. AgeE \& D. Johnson, supra note 344, at 11-13; Spurr, The Natural Resource Ecosystem, in The Ecosystem Concept in Natural Resource Management, supra note 24, at 4-7; T. Clark \& A. Harvey, supra note 344 , at $19-20$.

386. These include such standards as the MU-SY Act's sustained-yield principle, the ESA conservation requirement, the NFMA and NEPA biological diversity provisions, and other technicallyframed NFMA management obligations. See generally supra notes 209-27, 357-62 and accompanying text. Thus, an ecosystem management policy based upon scientific principles should not be perceived as threatening to Park Service and Forest Service officials charged with implementing it in the unfamiliar, and potentially threatening, setting of an interagency committee or the like. 
tive aspects of science give a distinctly objective flavor to management policy decisions and thus should afford land managers a measure of insulation from political pressures.

Plainly, the most difficult problem the GYCC confronts in constructing an ecosystem management policy that accords priority to the region's nationally significant natural features is how to insure local economic stablility. In an area well known for its resentment of federal intrusions, this will require sensitive judgments about community economic stability, distinctive cultural traditions, and the rate at which change can be assimilated. Moreover, both the Forest Service and Park Service must be prepared to reassess, and perhaps compromise, long-standing agency traditions and values. However difficult these sensitive judgments may be, it is a task largely within the agencies' discretionary administrative authority, and one that is well suited to a locally crafted solution.

One promising comprehensive model is the Biosphere Reserve concept, which links the preservationist goal of maintaining biological diversity with sustainable economic development principles. ${ }^{387}$ Without rearranging jurisdictional boundaries, the concept envisions a core of preserved lands surrounded by lands zoned to permit different levels of disturbance (or development), with minimum-impact development sanctioned on lands near the core area and more intensive activity permitted on those further away. Thus, while restraints might be placed on activities such as logging and mineral exploration in ecologically sensitive areas near the core, these activities would not be precluded throughout the region. To accomodate such changes, the agencies could utilize a "phase-in" process and, as the Forest Service has al-

387. The Biosphere Reserve concept originated in the United Nations Educational, Scientific and Cultural Organization's (UNESCO's) "Man in the Biosphere" program, and is designed to insure species diversity throughout the world by designating representative ecosystems as Reserves. The program's goals are to protect representative ecosystems, promote scientific research and public education, and insure local economic opportunities. Yellowstone National Park was designated an International Biosphere Reserve in 1976. See Miller, Biosphere Reserves in Concept and Practice, in TowARDs THE Biosphere Reserve: Exploring Relationships Between Parks and adjacent lands 7-21 (R.C. Scace \& C.J. Martinka eds. 1983); Sax \& Keiter, supra note 20, at 253-57. See also T. MCNamee, Nature First: Keeping OUR Wild Places and Wild Creatures Wild 45-50 (1987) (proposing creation of a National Biosphere Reserve system); Salwasser, Schonewald-Cox, \& Baker, supra note 35, at 166-72 (proposing conservation networks to sustain species population viability); $\mathbf{R}$. $\mathbf{E}$. Grumbine, Native Diversity or the Natural Zoo: Reframing Conservation Biology (1988) (unpublished manuscript available from author) (proposing sustainable biosphere reserves); Gilbert, Cooperation in Ecosystem Management, in Ecosystem Management for Parks and Wilderness, supra note 24, at 180-92 (discussing the biosphere reserve concept and the southern Appalachian Mountains). 
ready done in the case of Dubois, provide economic and technical assistance. $^{388}$

The economic health of the Yellowstone region is tied directly to the natural setting. Tourism is the principal economic activity throughout much of the region. ${ }^{389}$ Local communities, seeking to stabilize their economies, are expanding tourism facilities and promotion efforts, and the tourist season is being extended through the winter months. ${ }^{390}$ But relying primarily upon tourism as the economic base will not eliminate pressure on the region's natural values. Indeed, proposals such as the Ski Yellowstone resort and retention of the Fishing Bridge campground raise difficult questions about how a tourismbased economy can be sustained in a wilderness-like setting without jeopardizing natural values. Even the Park Service is learning it too may be faced with compromising important values to accomodate a regional economy based upon tourism and nonconsumptive use. ${ }^{391}$ On the national forests, intensive development proposals-exemplified recently by the expansion request for the Grand Targhee Ski Area in the Targhee National Forest ${ }^{392}$-will most likely surface more frequently, posing conflicts with wildlife needs and scenic values. ${ }^{393}$ Yet, with a coherent set of ecosystem-based management standards derived from clearly defined regional priorities, agency officials should have a principled basis for addressing these issues.

Nature's time clock is running, however. With development pressures mounting daily in different corners of the Yellowstone ecosystem, unique resources such as the grizzly bear and geyser system remain at risk, while roadless forest lands are being lost to the bulldozer and chainsaw. If the agencies fail to move decisively, with vision and boldness, they run the risk of losing control over events (as

388. See supra note 247. Cf. 16 U.S.C.S. $\$ 79 k, 1$ (1988 Supp.) (providing federal economic assistance to offset local impacts from the Redwood National Park expansion).

389. See supra notes 44,70 and accompanying text.

390. See supra note 96 and accompanying text.

391. This is illustrated quite plainly by the request from the State of Wyoming and several local communities to open Grand Teton National Park to snowmobile access to complete a proposed Continental Divide Snowmobile Trail. The trail is designed to enhance winter recreational and tourism opportunities in northwestern Wyoming, primarily for the towns of Dubois, Lander, and Riverton. Ironically, this proposal probably can be traced to the demise of logging and mining in the area surrounding Dubois. Thus, it presages the type of demands that could be placed upon the parks and other public lands with a transition from traditional extractive economic activities to a tourism and recreation-based regional economy. See NewSLetTer-Joint WinTer UsE PlaN, supra note 96.

392. See Casper Star Trib., Apr. 28, 1988, at B1.

393. At the same time, local communities probably can anticipate more conflicts over private land development proposals. More visitors and tourists will demand more services and facilities, which will insure additional, cumulative impacts on wildlife habitat and the area's natural values. See, e.g., supra note 165 (explaining that private development accompanying the Ski Yellowstone proposal will impact grizzly bear habitat). 
may have occurred already with oil and gas activity). ${ }^{394}$ Land managers, as well as their constituents, face the very real prospect of either an imposed congressional solution or further burdensome litigation accompanied by the threat of judicial intervention. Should the agencies default by failing to articulate a compelling future agenda that includes functional, transboundary resource management policies, Congress and the courts will step in-undoubtedly starting from the premise that the land managers enjoy too much, not too little, unchanneled discretion. In short, either the agencies, acting within the existing statutory framework and utilizing their inherent discretionary authority, can develop a meaningful "common law" of ecosystem management, or Congress and the courts can take over responsibility for insuring the ecological integrity of the Greater Yellowstone region.

Whether it is by bold administrative initiatives, congressional mandate, or perhaps even judicial fiat, the inexorable march of events in the Yellowstone region appears destined to conclude with de jure recognition of the Greater Yellowstone region as the relevant management entity. At least the important dialogue over what ecosystem management means is now underway before the region's natural treasures are lost. The principal players still have an opportunity to shape their own destiny and to craft a future sensitive to local economic needs and cultural traditions. But time is growing short to take the effective action needed to insure the integrity of Greater Yellowstone's unique and irreplaceable wildland resources.

\section{ConClusion}

Yellowstone's high visibility and national significance assure that what happens there will have a pronounced influence on the public lands elsewhere. Similar calls for ecosystem-based management are being heard in the Glacier National Park region of northwestern Montana, the North Cascades region of Washington State, and the Colorado Plateau of southern Utah. In each of these settings, major national parks and wilderness areas are intermixed with large expanses of multiple-use public lands. Conflict is intense between preservationists determined to minimize man's impact on the natural environment and the extractive industries eager to maintain their traditional access rights to public resources. As in the Yellowstone region, workable solutions to these conflicts will require cooperative management approaches and a willingness to rethink traditional land use priorities.

Some lessons from this excursus through the Yellowstone experi-

394. See supra notes $286-90$ and accompanying text. 
ence are clear enough, even if the ramifications are as yet only partly understood. In significant respects, the law breaches conventional boundary lines on the public domain; it not only provides specific legal protection for ecosystem components, but also endorses the principle of ecosystem management. The land management agencies have themselves given de facto recognition to a Greater Yellowstone ecosystem and created their own "process" for addressing transboundary issues. Their administrative initiatives reflect the rudimentary beginnings of a "common law" of ecosystem management. But whether the agencies-given their divergent management principles and the strong passions of their constituent groups-are capable institutionally of transcending the boundary mentality to articulate a regional vision that fully integrates ecological imperatives with individual human interests remains uncertain. Moreover, whether the agencies can overcome their traditional preoccupation with managerial discretion to establish meaningful ecosystem-based management standards remains unclear.

Inevitably, however, Greater Yellowstone's future will be shaped by, and ultimately will reflect, evolving national public values. The ecosystem concept interjects a provocative new image into the debates that are now influencing and molding public lands policy. Scientifically, the concept demonstrates the indisputable interconnectedness of jurisdictionally fragmented public lands. And the concept has great power as a metaphorical device, rooted in scientific fact yet evocative enough to stir the hearts and minds of an American public now strongly committed to the preservationist ideal and its national parks heritage. Already the Greater Yellowstone Ecosystem concept has fused two world-renowned national parks, several well-known wilderness areas, and the adjoining national forest lands into a regional entity that has engaged public attention at national and international levels. It has broadened the perspective of land managers beyond their own borders, and it is transforming traditional conceptions of land management policy. In short, the ecosystem concept provides the fundamental premise for regional management and thus brings a compelling new vision to the ongoing debate over the future of the public domain. 